Pacific Northwest

National Laboratory

Qperated by Battelle for the

U.S. Department of Energy

\section{Evaluation of Groundwater \\ Monitoring Results at the Hanford Site 200 Area Treated Effluent Disposal Facility}

D. B. Barnett

September 1998

\section{RECEIVED}

OCT 131998

OSTI

\section{MASTER}

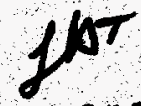

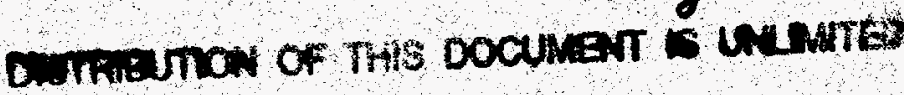

Prepared for the U.S. Department of Energy under Contract DE-AC06-76RLO 1830 


\title{
DISCLAIMER
}

This report was prepared as an account of work sponsored by an agency of the United States Government. Reference herein to any specific commercial product, process, or service by trade name, trademark, manufacturer, or otherwise does not necessarily constitute or imply its endorsement, recommendation, or favoring by the United States Government or any agency thereof, or Battelle Memorial Institute.

\author{
PACIFIC NORTHWEST NATIONAL LABORATORY \\ operated by \\ BATTELLE \\ for the
}

UNITED STATES DEPARTMENT OF ENERGY

under Contract DE-ACO6-76RLO 1830

Printed in the United States of America

Available to DOE and DOE contractors from the

Office of Scientific and Technical Information, P.O. Box 62, Oak Ridge, TN 37831; prices available from (615) $576-8401$.

Available to the public from the National Technical Information Service, U.S. Department of Commerce, 5285 Port Royal Rd,, Springfield, VA 22161 


\section{DISCLAIMER}

\section{Portions of this document may be illegible in electronic image products. Images are produced from the best available original document.}




\section{Evaluation of Groundwater Monitoring Results at the Hanford Site 200 Area Treated Effluent Disposal Facility}

D. B. Barnett

September 1998

Prepared for the U.S. Department of Energy under Contract DE-AC06-76RLO 1830

Pacific Northwest National Laboratory Richland, Washington 99352 



\section{Summary}

The Hanford Site 200 Area Treated Effluent Disposal Facility (TEDF) has operated since June 1995. Groundwater monitoring has been conducted quarterly in the three wells surrounding the facility since 1992, with contributing data from nearby B Pond System wells.

Cumulative hydrologic and geochemical information from the TEDF well network and other surrounding wells indicate no discernable effects of TEDF operations on the uppermost aquifer in the vicinity of the TEDF. The lateral consistency and impermeable nature of the Ringold Formation lower mud unit, and the contrasts in hydraulic conductivity between this unit and the vadose zone sediments of the Hanford formation suggest that TEDF effluent is spreading laterally with negligible mounding or downward movement into the uppermost aquifer.

Hydrographs of TEDF wells show that TEDF operations have had no detectable effects on hydraulic heads in the uppermost aquifer, but show a continuing decay of the hydraulic mound generated by past operations at the B Pond System. Comparison of heads in the uppermost aquifer immediately northwest of the TEDF with the head in a well in the same area which is screened in the Rattlesnake Ridge Interbed. (upper basalt confined aquifer), indicate that hydraulic heads in the two aquifers are converging as the hydraulic mound at the B Pond System subsides. Further southeast, near TEDF, an upward hydraulic gradient may already exist, making potential of incursion of groundwater from the upper basalt confined aquifer to the unconfined aquifer (uppermost aquifer beneath TEDF) more likely. This condition would further hamper downward movement of effluent of TEDF into the uppermost aquifer, particularly if no substantial groundwater mound is created beneath the TEDF.

Comparison of groundwater geochemistry from TEDF wells and other, nearby RCRA wells suggests that groundwater beneath TEDF is unique; different from both effluent entering TEDF and groundwater in the B Pond area. Tritium concentrations, major ionic proportions, and lower-than-background concentrations of other species suggest that groundwater in the uppermost aquifer beneath the TEDF bears characteristics of water in the upper basalt confined aquifer system.

This report recommends retaining the current groundwater well network at the TEDF, but with a reduction of sampling/analysis frequency and some modifications to the list of constituents sought. 



\section{Acknowledgments}

The author deeply appreciates the critical review of the document by M. J. Hartman, P. C. Mohondro, D. L. Flyckt, P. M. Olson, P. E. Dresel, Dr. R. G. Riley, and W. D. Webber. Special thanks go to W. D. Webber, who supplied the Stiff diagram plots and engaged the author in helpful discussions of groundwater chemistry and hydrology, and Dr. E. C. Thornton, who provided the charge-balance spreadsheet, technical review, and helpful discussion of major ion chemistry. 



\section{Acronyms and Symbols}

BAT/AKART

CDL

DMR

DWS

FADE

gpm

HEIS

$\mathrm{K}_{\mathrm{d}}$

$\mathbf{K}_{\mathrm{s}}$

LEMIS

MODFLOW

PQL

PUREX

RCRA

SWDP

TDS

TEDF

TOC

TOX

VAM3DCG best available technology/all known and reasonable treatment contract detection limits

Discharge Monitoring Reports

Drinking Water Standards

Factors of Attenuation and Dilution Efficacy

gallons per minute

Hanford Environmental Information System

Coefficient of Distribution

saturated hydraulic conductivity

Liquid Effluent Monitoring Information System

MODular three-dimensional finite-difference ground-water FLOW model

Practical Quantitation Levels

Plutonium-Uranium Extraction (Plant)

Resource Conservation and Recovery Act

State Waste Discharge Permit

total dissolved solids

200 Area Treated Effluent Disposal Facility

total organic carbon

total organic halogens

Variably Saturated Analysis Model in Three Dimensions with

Preconditioned Conjugate Gradient Matrix Solvers 



\section{Contents}

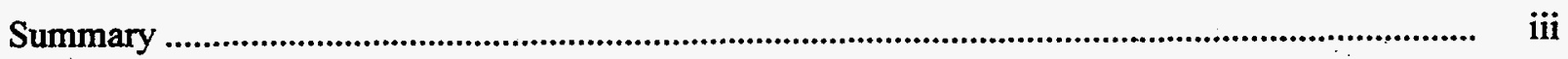

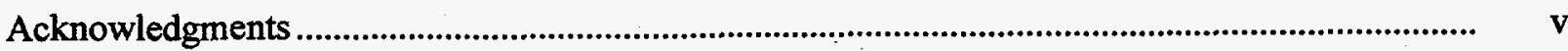

Acronyms and Symbols................................................................................................................... vii

1.0 Introduction ............................................................................................................... 1.1

1.1 Objectives and Scope............................................................................................... 1.1

1.2 Background and Facility Overview ............................................................................ 1.1

1.3 Wastewater Discharge Volumes and Characteristics ................................................... 1.7

2.0 Historical and Current Groundwater Monitoring at TEDF ..................................................... 2.1

2.1 Monitoring Well Network ............................................................................................ 2.1

2.2 Evolution of Constituents List ........................................................................................ 2.1

2.3 Sampling and Analysis ............................................................................................... 2.2

2.4 Data Storage and Evaluation .......................................................................................... 2.2

3.0 Summary of Hydrogeology and Groundwater Modeling ........................................................ 3.1

3.1 Geologic Framework ......................................................................................................... 3.1

3.2 Groundwater Hydrology ........................................................................................... 3.4

3.3 Monitoring Well Locations................................................................................................ 3.9

3.4 Summary of Groundwater Modeling Results ............................................................. 3.10

3.4.1 Groundwater Flow Modeling ............................................................................. 3.10

3.4.2 Contaminant Transport Modeling............................................................................ 3.11

3.5 Discussion of Hydrogeology and Modeling Results .................................................... 3.12

4.0 Summary of Groundwater Geochemistry ...................................................................................

4.1 Synopsis of Analytical Results ....................................................................................... 4.1

4.2 Major Ion Chemistry................................................................................................... 4.7

4.3 Discussion of TEDF Groundwater Geochemistry .......................................................... 4.10 
6.0 Conclusions and Recommendations.

7.0 References.

Appendix A - Summary Lithologic Logs and Construction Details for TEDF Groundwater Monitoring Wells.

Appendix B - Groundwater Constituents Lists for the 200 Area TEDF

B.1

Appendix C - Charge Balance Calculations for Wells in the Vicinity of the TEDF

C.1 


\section{Figures}

1.1 Location of the 200 Area Treated Effluent Disposal Facility .................................................. 1.2

1.2 Schematic Diagram of the Effluent Collection System for the TEDF.................................... 1.5

1.3 Location of Groundwater Monitoring Wells in the Vicinity of the TEDF ............................ 1.6

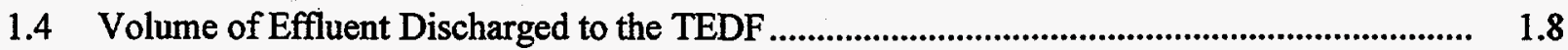

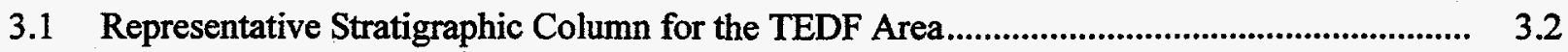

3.2 Schematic Cross Section of Suprabasalt Sediments in the TEDF/B Pond Area ..................... 3.3

3.3 An Interpretation of Thickness and Distribution of the Ringold Lower Mud Unit .................. 3.5

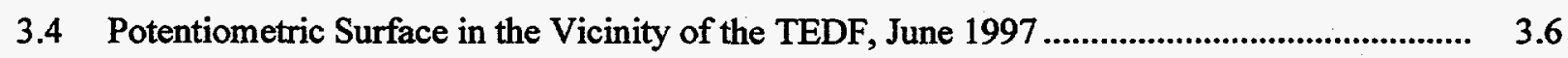

3.5 Hydrographs of TEDF Groundwater Monitoring Wells................................................ 3.7

3.6 Comparison of Observed Hydraulic Heads for the Upper Basalt Confined and Overlying Unconfined Aquifer Systems ................................................................................. $\quad 3.8$

3.7 Composite Hydrograph of Well 699-42-40C in the Rattlesnake Ridge Interbed of the Upper Basalt Confined Aquifer System and Nearby Wells Completed in the Unconfined Aquifer System.

4.1 Plots of Gross Alpha and Gross Beta Results from TEDF Wells...................................... 4.8

4.2 Stiff Diagrams for Wells in the Unconfined Aquifer in the Vicinity of the TEDF ................ 4.9

4.3 Stiff Diagrams and Age Estimates for Groundwaters and Surface Waters in the Vicinity of the Hanford Site

4.4 Hydrochemical Facies Stiff Diagram Map for Groundwater Within the Upper Basalt Confined Aquifer System 


\section{Plates.}

1.1 Westward View of the TEDF with Southern Basin in Operation; 3C Expansion Pond of the B Pond System in Middle Distance, and 200 Areas in Background................................. 1.3

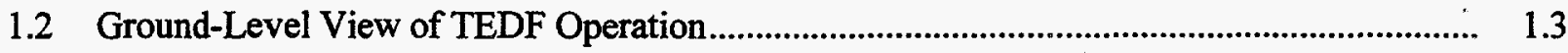

\section{Tables}

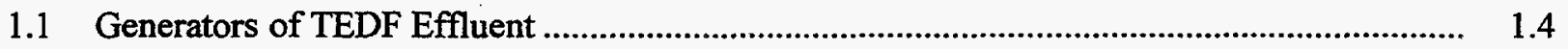

2.1 Current Constituent and Parameters List for Quarterly Groundwater Monitoring at the 200 Area TEDF.................................................................................................... 2.3

4.1 Constituents from the Original TEDF Analyte List with at Least One Result Exceeding PQL in Well 699-40-36

4.2 Constituents from the Original TEDF Analyte List with at Least One Result Exceeding $\mathrm{PQL}$ in Well 699-41-35.

4.3 Constituents from the Original TEDF Analyte List with at Least One Result Exceeding PQL in Well 699-42-37. 


\subsection{Introduction}

The 200 Area Treated Effluent Disposal Facility (TEDF) receives wastewater originating from the 200 East and 200 West Areas of the Hanford Site. The TEDF consists of two infiltration basins that alternate usage on a regular basis. The wastewater consists primarily of steam condensate, raw water, cooling water, and other uncontaminated aqueous wastes that are treated, if needed, at the generating facilities, then discharged to the TEDF. Groundwater monitoring at the site of the facility has been ongoing since 1992. In 1995, groundwater monitoring requirements were enhanced to comply with State Waste Discharge Permit ST 4502 (SWDP) administered by the Washington State Department of Ecology (Ecology 1995, WAC 173-216). The purpose of this report is to summarize information collected since the beginning of operations, with emphasis on the period 1995 to present. This information is used to evaluate ongoing groundwater monitoring needs at the TEDF.

\subsection{Objectives and Scope}

This report describes groundwater monitoring efforts at the TEDF since 1992, and summarizes all previous characterization efforts of the site in terms of hydrogeological and geochemical evaluation. Additional information not previously discussed in other reports, collected mostly since 1995, is presented in conjunction with the earlier characterizations for continuity. Salient aspects of geochemistry results from the groundwater sampling program are presented and discussed. Geochemical and hydrogeological information is synthesized into a conceptual model for effluent fate. This conceptual model is then used as the basis to evaluate the approach to groundwater monitoring at the facility.

\subsection{Background and Facility Overview}

The TEDF is located approximately $3 \mathrm{~km}$ east of the 200 East Area of the Hanford Site (Figure 1.1). This location was selected from four candidate sites at the conclusion of drilling and testing activities in 1992. These activities determined that the soil beneath the site is clean (not contaminated) and that operation would not have an effect on potential soil contamination associated with the B Pond System. The two 5-acre basins that receive effluent on alternating schedules are located just east of the $3 \mathrm{C}$ expansion pond of the former 216-B-3 Pond System (Plates 1.1 and 1.2). Many of the effluent streams that the TEDF now receives were diverted from the B Pond System, and most recently from the $3 \mathrm{C}$ expansion pond.

Operation began in June 1995 when some of the effluent streams to the $3 \mathrm{C}$ expansion pond were rerouted to the TEDF along with some 200 West Area streams. In August 1997, some additional streams, which had been discharging to the $3 \mathrm{C}$ expansion pond, were redirected to the TEDF. Additional discharge information is presented in Section 1.3. 


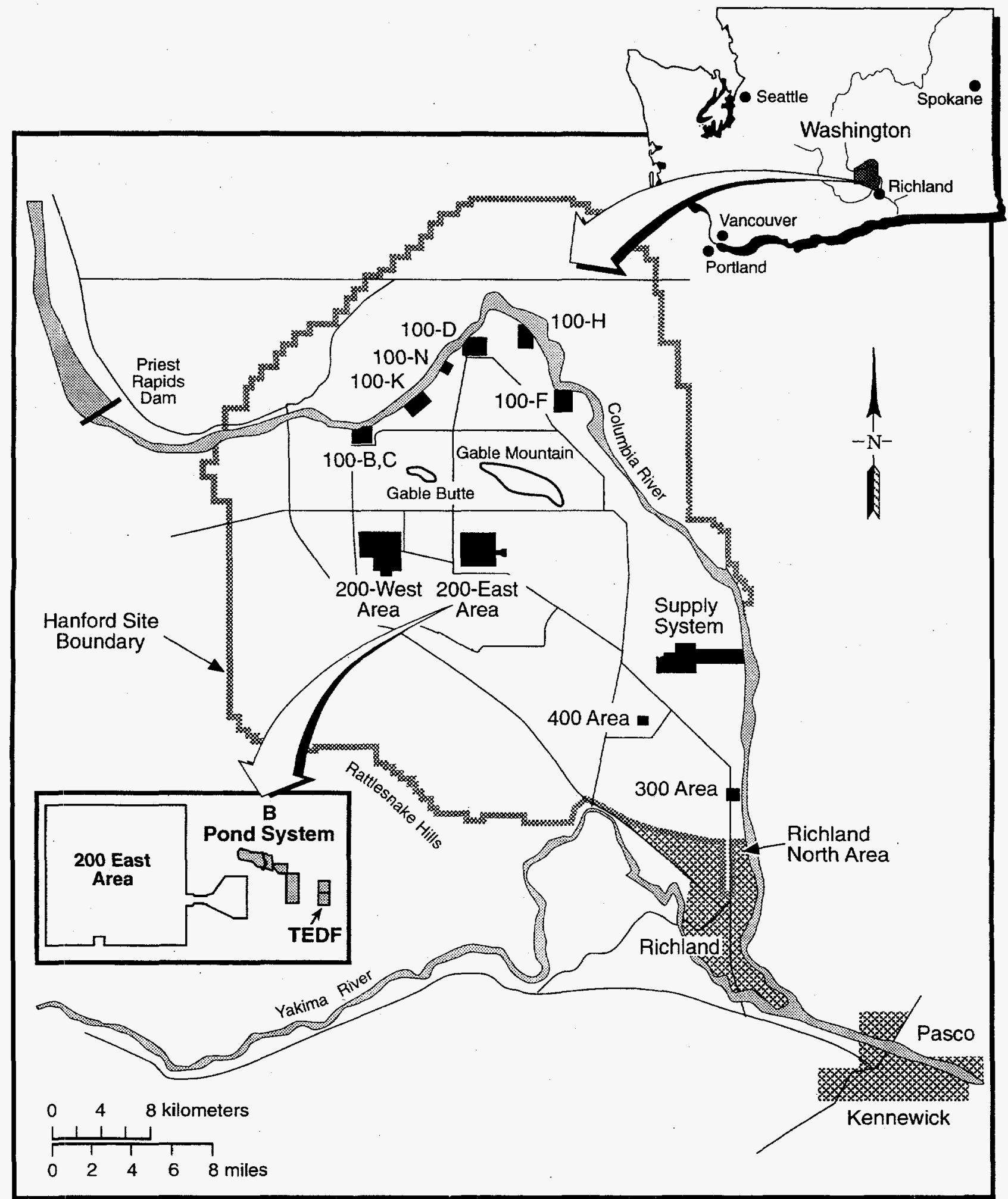

RG98060028.3

Figure 1.1. Location of the 200 Area Treated Effluent Disposal Facility (TEDF) 

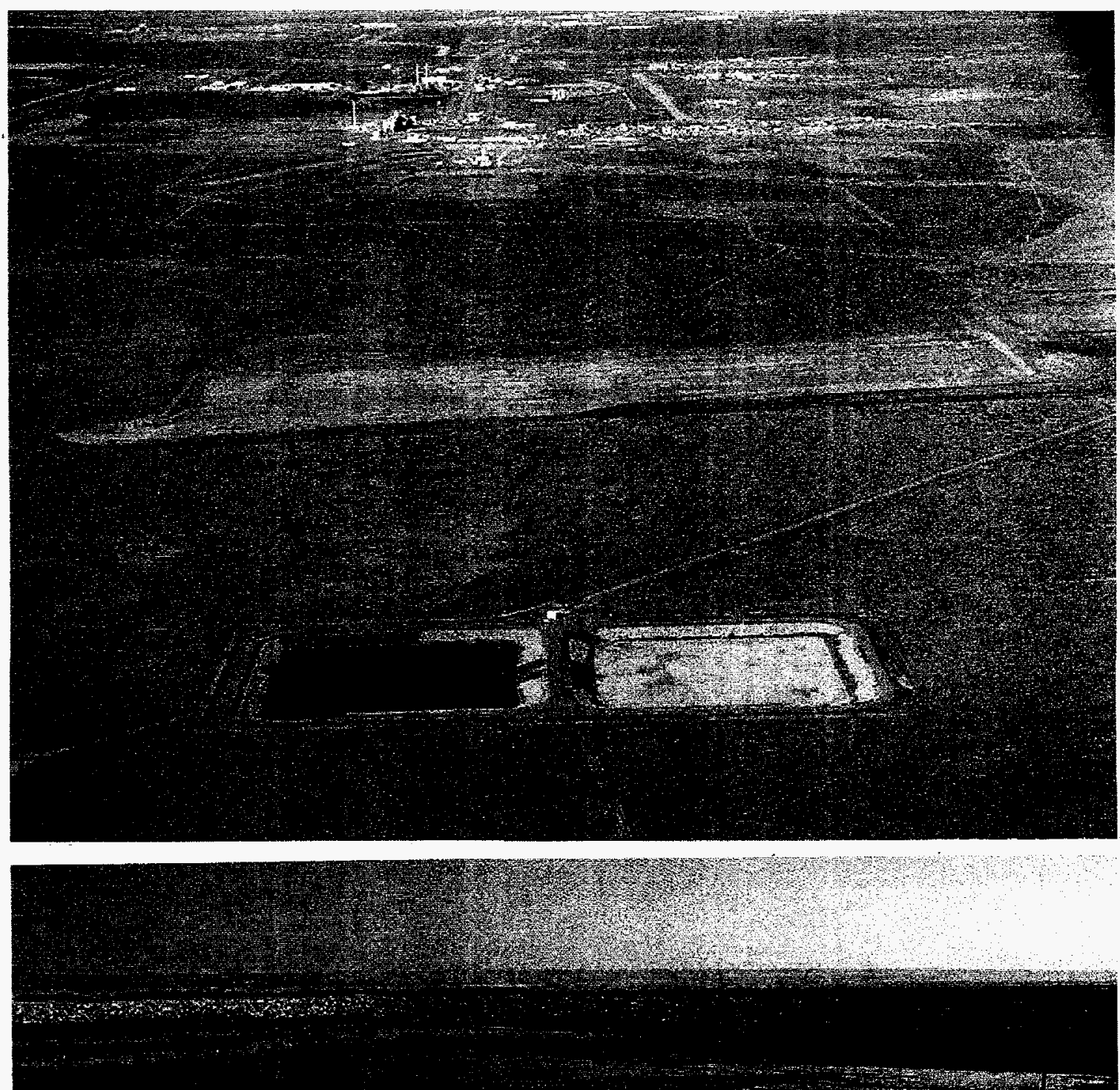

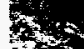

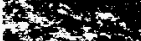

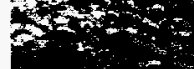

格
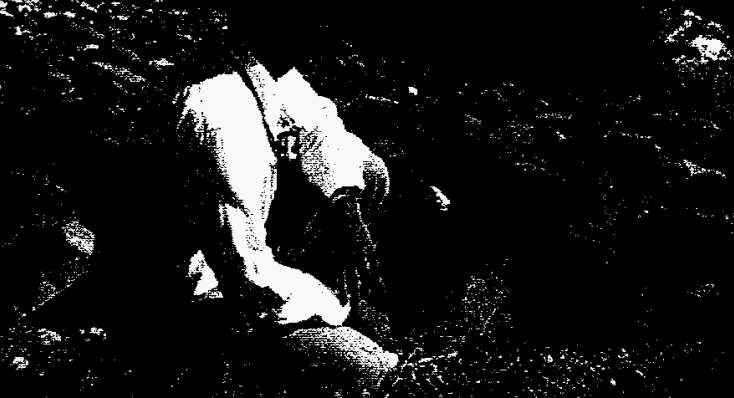

Plates 1.1 and 1.2. (Top) Westward View of the TEDF with Southern Basin in Operation; 3C Expansion Pond of the B Pond System in Middle Distance, and 200 Areas in Background. (Bottom) Ground-Level View of TEDF Operation (Northern Basin). 
Current sources of effluent reaching the TEDF consist mostly of steam condensate and raw water (Columbia River water). Table 1.1 lists these source generators. Former sources included the B Plant and Plutonium-Uranium Extraction (PUREX) Plant chemical sewers. All effluent streams have been subjected to best available technology/all known and reasonable treatment (BAT/AKART) criteria at the generating facilities before they are conveyed to the TEDF. Figure 1.2 schematically illustrates the collection system with major sources of effluent directed to the TEDF.

Groundwater monitoring at the TEDF began in late 1992 upon completion of the three test wells, which were constructed as Resource Conservation and Recovery Act (RCRA)-compliant monitoring wells. From 1992 until early 1995, these three wells were monitored under the RCRA program as part of the 216-B-3 Pond System network. When operation of the TEDF facility began in 1995, groundwater monitoring continued under the provisions and schedule dictated by the SWDP (see Section 2.0). Locations of the wells are shown in Figure 1.3. Groundwater samples have been collected quarterly since monitoring began in 1992.

Table 1.1. Generators of TEDF Effluent (after Crane 1998)

\begin{tabular}{||l|l||}
\hline \multicolumn{1}{|c|}{ Facility } & \multicolumn{1}{c|}{ Wastestream } \\
\hline \hline Plutonium Finishing Plant (PFP) & PFP Wastewater \\
\hline 222-S Laboratory & 222-S Laboratory Wastewater \\
\hline 222-S Package Boiler Annex & 222-S Package Boiler Annex \\
\hline T Plant & T Plant Wastewater \\
\hline 284-W Power Plant & 284-W Power Plant Wastewater \\
\hline 283-W Package Boiler Annex & 283-W Package Boiler Annex \\
\hline \multirow{2}{*}{ WESF } & WESF Liquid Effluent \\
\cline { 2 - 3 } & WESF Cooling Water \\
\hline 225B-BA Package Boiler Annex & 225B-BA Package Boiler Annex \\
\hline 241-A & 241-A Tank Farm Cooling Water \\
\hline 242-A Evaporator & 242-A-81 Water Services Building Wastewater \\
\cline { 2 - 3 } & 242-A Cooling Water \\
\cline { 2 - 3 } & 242-A Steam Condensate \\
\hline 242-A Package Boiler Annex & 242-A Package Boiler Annex \\
\hline 244-AR & 244-AR Cooling Water \\
\hline 284-E Power Plant & 284-E Power Plant Wastewater \\
\hline 283-E Package Boiler Annex & 283-E Package Boiler Annex \\
\hline
\end{tabular}




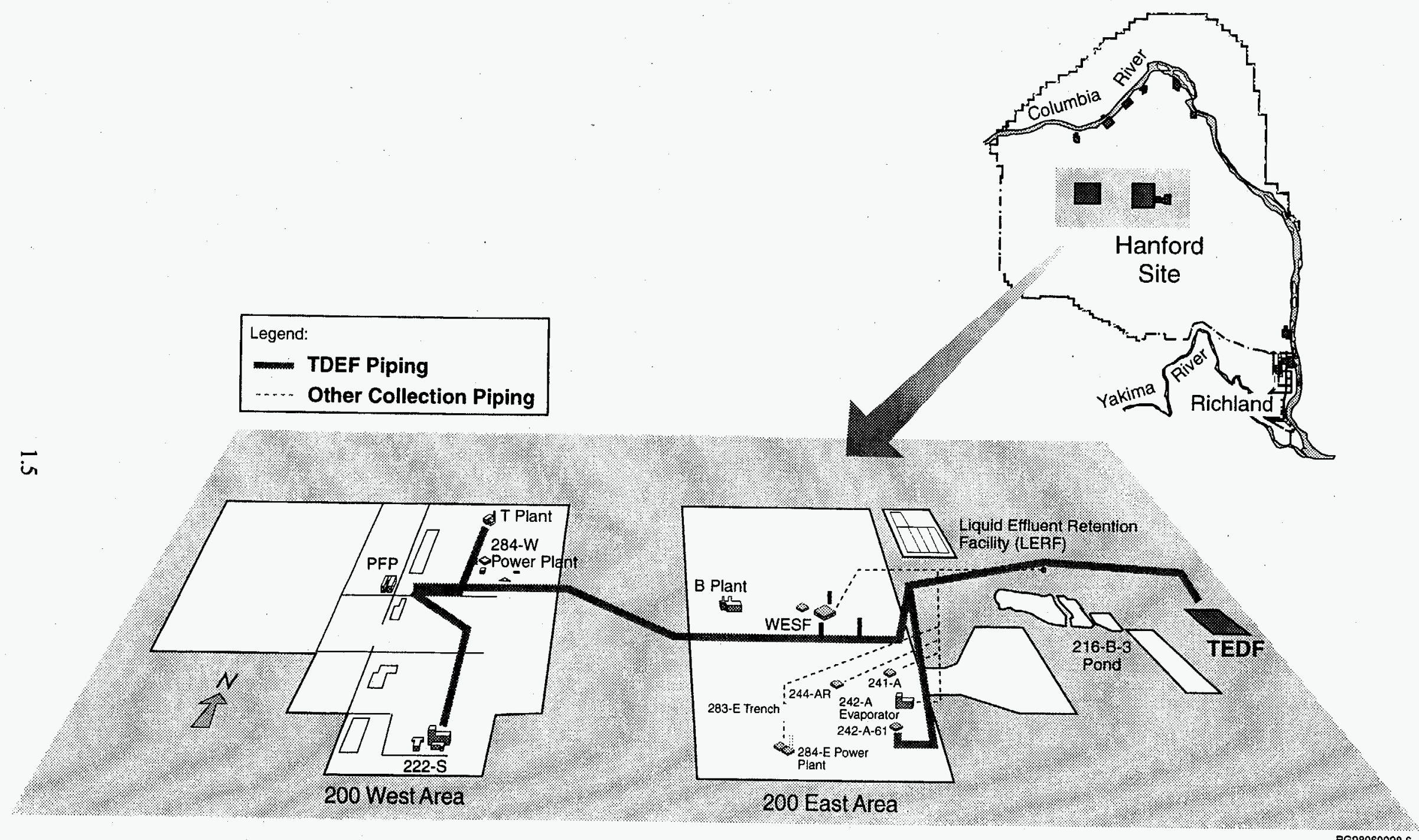

Figure 1.2. Schematic Diagram of the Effluent Collection System for the TEDF 


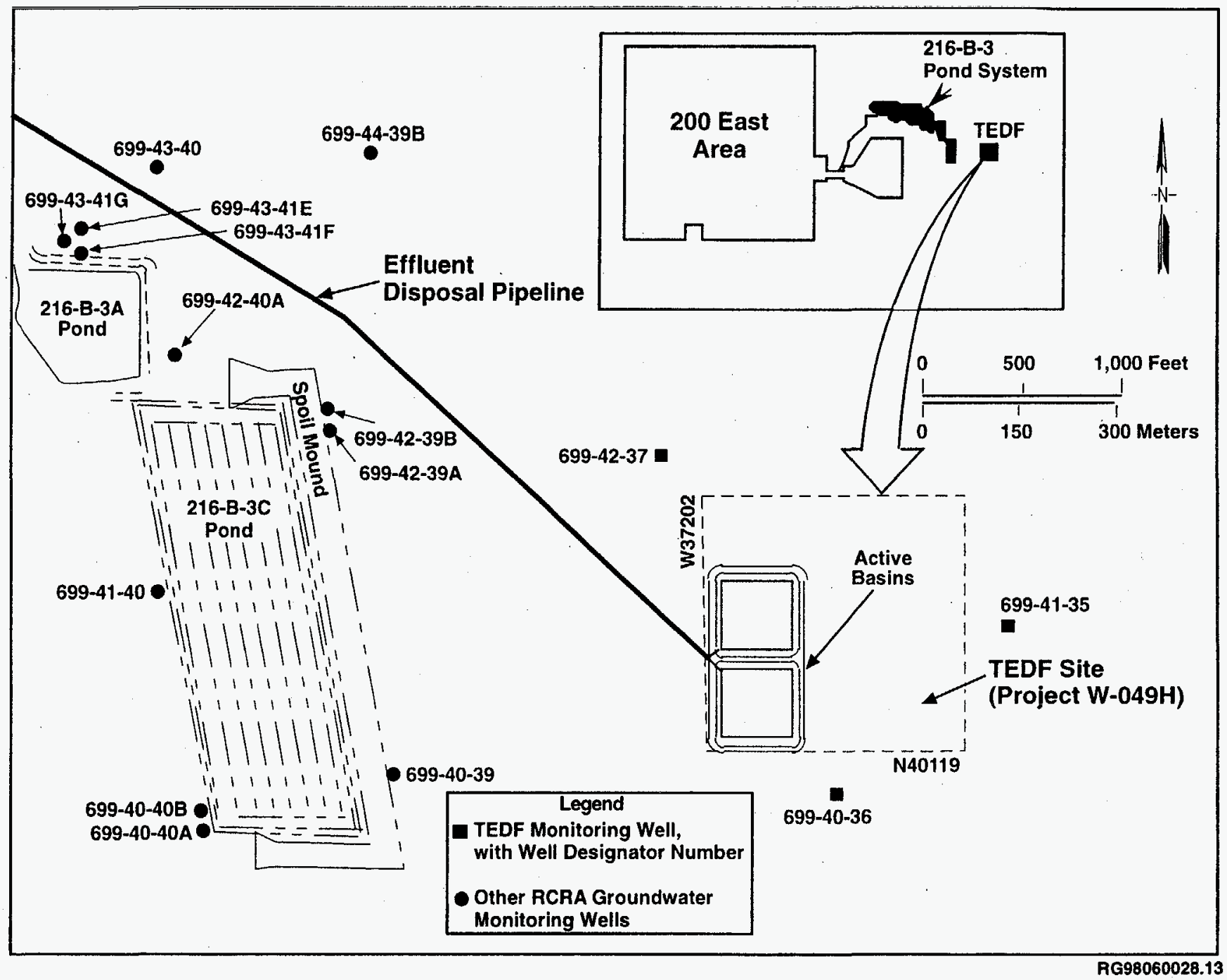

Figure 1.3. Location of Groundwater Monitoring Wells in the Vicinity of the TEDF 


\subsection{Wastewater Discharge Volumes and Characteristics}

Effluent volumes released to the TEDF have been within permitted operating parameters since the beginning of operations in 1995. Regulated capacity of the TEDF for each of the two basins was initially approximately $2820 \mathrm{~L} / \mathrm{min}$ ( 750 gallons per minute [gpm]) (Barnett et al. 1995). In April 1997, a revised SWDP was issued that requires discharges not exceed $12,870 \mathrm{~L} / \mathrm{min}(3,400 \mathrm{gpm})$ on a monthly basis, averaged daily, or 4,540 L/min (1,200 gpm) on an average annual basis. The permit revision also allowed for additional waste streams to be accepted by the facility. Figure 1.4 is a plot of monthly and cumulative discharge volumes to the TEDF through May 1998. Thus far, over 2.5 billion liters have been discharged to the facility. As Figure 1.4 illustrates, volumes have been highly variable during the most recent 1 year. A significant increase in discharges is seen from August 1997 onward, due to diversion of streams from the 3C Expansion Pond of the B Pond System.

Chemical constituents of the waste stream are monitored in the effluent at frequencies of 4 times per month to monthly, depending on the constituent. Flow, $\mathrm{pH}$, and conductivity are monitored continuously near the discharge point. The SWDP (Sections S.3 and S.4) lists enforcement limits and early warning values for the constituents of concern.

Analyses of TEDF effluent from July 1995 to April 1996 were statistically evaluated to determine if any constituents might be expected to exceed permit limits in the effluent (Chou and Johnson 1996). Of the constituents regulated in the permit, only iron and chloride were demonstrated to occur in concentrations in the effluent that may exceed enforcement limits. All other constituents were shown to have $<0.0001$ percent probability of exceeding permit limits. In fact, only iron has exceeded permit limits in effluent since TEDF operations began. These exceedences occurred twice; during the April-to-July period of 1996 and during the January-to-March period of 1997. Reports to Ecology state that the elevated iron is thought to be a result of rust originating from conveyance piping. Chloride has not exceeded permit limits in the TEDF effluent. 


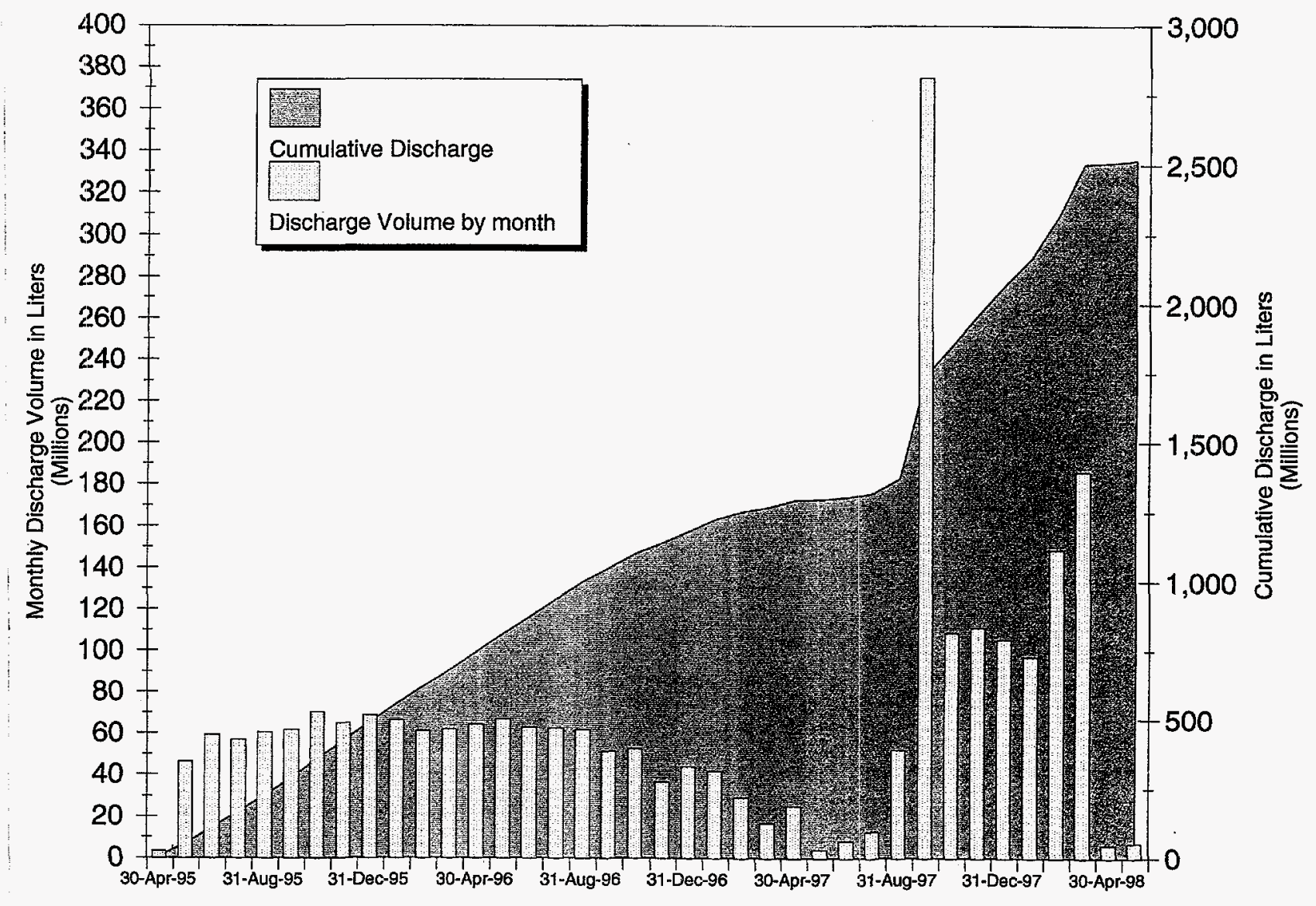

Figure 1.4. Volume of Effluent Discharged to the TEDF 


\subsection{Historical and Current Groundwater Monitoring at TEDF}

This section briefly summarizes the progression of groundwater monitoring at the TEDF and the rationale for the derivation of constituent lists and the well network. Immediately following construction of the TEDF monitoring wells in 1992, groundwater monitoring at the site began under the Hanford Site RCRA program in conjunction with the 216-B-3 Pond facility (DOE-RL 1994). When operation of TEDF began in 1995, groundwater monitoring was governed by the SWDP and described in Groundwater Screening/Evaluation Monitoring Plan-200 Area Treated Effluent Disposal Facility (Project $W$-049H) (Barnett et al. 1995). Conditions of the SWDP also require that groundwater monitoring is conducted according to WAC 173-200, Water Quality Standards for Ground Waters of the State of Washington (Ecology 1997).

\subsection{Monitoring Well Network}

Groundwater monitoring requirements for the TEDF were initially determined to be similar to RCRA-regulated facilities (40 CFR 265, Subpart F). This determination is reflected in Special Condition S. 7 of the SWDP. One upgradient well and two downgradient wells were constructed near the perimeter of the facility to monitor groundwater in the uppermost aquifer (see Figure 1.3). General construction parameters and lithologic settings for the three facility wells (699-40-36, 699-41-35, and 699-42-37 [upgradient well]) are shown in Appendix A. All three wells were completed in 1992 as "RCRA-compliant" wells (WAC 173-160). Following emplacement and testing of these wells, it was recognized that peculiar hydrogeologic conditions existed at the site, that may eventually require reevaluation of the groundwater monitoring. Section 3.0 elaborates on the hydrogeologic framework of the facility and the rationale for selecting well locations.

\subsection{Evolution of Constituents List}

From 1992 until 1995, the sampling schedule and list of constituents for which the three TEDF wells were sampled followed those for the nearby B Pond System, a RCRA facility that was in a groundwater quality assessment status (quarterly sampling) during that period. Until TEDF operations began, and specific constituents of concern were established in the SWDP, the B Pond constituent list was applied to the TEDF groundwater monitoring as a conservative measure for establishing background groundwater quality. During this period, each of the three wells was also sampled once for the Appendix IX (40 CFR 264) list of constituents. The constituent list that the TEDF wells shared with the B Pond System is attached in Appendix B (Table B.1).

In May 1995, the Groundwater Screening Evaluation/Monitoring Plan-200 Area Treated Effluent Disposal Facility (Project W-049H) (Barnett et al. 1995) was submitted to, and subsequently approved by Ecology to guide future groundwater sampling and analysis at the TEDF. The constituent list required by this document, as guided by the SWDP, is listed in Appendix B (Table B.2). This list was derived from 
the existing RCRA program list and includes additional parameters required by Ecology. The list represents a comprehensive suite of parameters for evaluating background groundwater quality at the site and screening for anomalous geochemical conditions. The list was applied quarterly until 1996.

In July 1996, the list of analytes for groundwater samples from TEDF wells was again revised following completion of 3 quarters ( 3 sample events during a 9-month period) of groundwater background evaluation. Several constituents were eliminated from the list in Table B.2, but the lists of metals and anions were somewhat expanded. Analytes consistently below detection were also eliminated from the list, and quarterly Discharge Monitoring Reports (DMR) were proposed as a medium to track and report quarterly groundwater monitoring results from TEDF. Ecology approved these revisions in accordance with discretionary latitude provided by the SWDP (Section S.8). The current list of analytes for the TEDF is shown in Table 2.1. This list includes all parameters required by the SWDP and additional parameters that are routinely included in the requested analyses. Samples for these constituents and water level measurements are currently collected quarterly.

\subsection{Sampling and Analysis}

Protocols for sampling and analysis of groundwater from TEDF wells are described in Liquid Waste Processing Facilities Quality Assurance Project Plan (Olson 1997). The Practical Quantitation Levels $(\mathrm{PQL})$ is the lowest level of concentration of a constituent that can be readily achieved by the laboratory for specified limits of precision and accuracy. PQLs for groundwater constituents in Table 2.1 are prescribed by the SWDP and are also listed by Olson (1997). The screening list of parameters in Table B.2 also lists these PQLs.

\subsection{Data Storage and Evaluation}

Field and laboratory analytical results from both effluent and groundwater monitoring at the TEDF are stored in the Liquid Effluent Monitoring Information System (LEMIS). This database contains both field and laboratory results. Groundwater analytical results from TEDF monitoring wells are regularly transferred from LEMIS to the Hanford Environmental Information System (HEIS) for technical evaluation. The uploading of information from LEMIS to HEIS occurs quarterly, or more frequently if specifically requested by the project scientist in charge of groundwater chemistry evaluation. 
Table 2.1. Current Constituent and Parameters List for Quarterly Groundwater Monitoring at the 200 Area TEDF

\begin{tabular}{|c|c|}
\hline Constituent & Method \\
\hline $\begin{array}{l}\text { Metals } \\
\text { Arsenic } \\
\text { Cadmium } \\
\text { Chromium } \\
\text { Mercury } \\
\text { Lead } \\
\text { Copper, selenium, uranium (total) } \\
\text { Aluminum, barium, beryllium, calcium, cobalt, iron, } \\
\text { magnesium, manganese, nickel, potassium, silicon, silver, } \\
\text { sodium, thallium, titanium, vanadium, zinc } \\
\text { Anions } \\
\text { Bromide, nitrate, sulfate, phosphate, chloride, fluoride, nitrite } \\
\text { as N } \\
\text { Volatile and Semivolatile Organic Compounds } \\
\text { Bis (2-hexylethyl) phthalate, phenol, 1,2,4-trichlorobenzene, } \\
\text { 1,4-dichlorobenzene, 2,4-dinitrotoluene, 2-chlorophenol, } \\
\text { 4-chloro-3-methylphenol, 4-nitrophenol, acenaphthene, } \\
\text { N-nitrosodi-n-propylamine, pentachlorophenol, pyrene } \\
\text { Total trihalomethanes, carbon tetrachloride, methylene } \\
\text { chloride, 1,1,1 trichloroethane, 1,1-dichloroethene, benzene, } \\
\text { bromodichloromethane, chlorobenzene, chloroform, } \\
\text { dibromochloromethane, trichloroethene } \\
\text { WTPH-G } \\
\text { Miscellaneous Parameters } \\
\text { Ammonia } \\
\text { Alkalinity, conductivity, pH, temperature } \\
\text { Cyanide } \\
\text { Total dissolved solids } \\
\text { Turbidity } \\
\text { Total Organic Carbon } \\
\text { Oil and Grease } \\
\text { Gross alpha } \\
\text { Gross beta } \\
\text { Radium } 226 \\
\text { Radium } 226+228\end{array}$ & $\begin{array}{l}\text { SW-846 } 8015 \mathrm{M} \\
40 \text { CFR } 136350.1 / 2 / 3 / E P A 300.7 \\
\text { Field analyses } \\
40 \text { CFR } 136335.1 / 2 / 3 / E P A 335.3 \\
40 \text { CFR } 136160.1 \\
\text { Standard Methods 214A (Field Analysis) } \\
\text { SW-846 } 9060 \\
\text { SW-846 } 9070 \\
\text { Gross Alpha (DGPC) } \\
\text { Gross Beta (DPC) } \\
\text { Radium-226 (AEA) } \\
\text { Radium-228 (GEA) }\end{array}$ \\
\hline
\end{tabular}




\subsection{Summary of Hydrogeology and Groundwater Modeling}

The information presented in this section draws mostly on previous work completed for TEDF site evaluation and hydrogeologic evaluations of the 200 East Area and vicinity. The hydrogeologic investigation that is most specifically focused on the TEDF is provided in Site Characterization Report: Results of Detailed Evaluation of the Suitability of the Site Proposed for Disposal of 200 Areas Treated Effluent (Davis et al. 1993). Stratigraphy of the 200 East Area adjoining the TEDF is described in greatest detail by Lindsey et al. (1992). Groundwater hydrology for the site is also described in detail by Davis et al. (1993), and more recent, pertinent information is provided by Hartman and Dresel (1998) and Barnett and Chou (1998) in connection with the B Pond System RCRA facility. Groundwater modeling efforts (conceptual and/or numerical) that generally apply to the TEDF and vicinity are described by Connelly et al. (1992), and more recently by Kincaid et al. (1998). Application of flow and transport modeling for the evaluation of the effects of TEDF operation is provided by Collard in Barnett et al. (1995).

\subsection{Geologic Framework}

The principal geologic units beneath the TEDF include the Columbia River Basalt Group, the Ringold Formation, and the Hanford formation. A representative stratigraphic column of these units beneath the TEDF is shown in Figure 3.1. A stylized cross section of the stratigraphy in the vicinity of the TEDF is shown in Figure 3.2. Appendix A also illustrates stratigraphy interpreted from drilling information from the three monitoring wells. Davis et al. (1993) describe these lithologic units in the vicinity of the TEDF in detail, and reference other reports that provide additional information. A brief synopsis of these reports is provided here.

Ringold Formation fluviolacustrine sediments average $\sim 45 \mathrm{~m}$ thick beneath the TEDF and consist of (in ascending stratigraphic order): 1) unit $A$ gravel and 2) lower mud unit. The Ringold unit $A$ gravel ranges in thickness from $\sim 25 \mathrm{~m}$ in well $699-40-36$, south of the TEDF to $\sim 37 \mathrm{~m}$ in well $699-42-37$, north of the facility. This unit is mainly composed of a silty sandy gravel with secondary lenses and interbeds of gravely sand, sand, and muddy sands to clay/silt. The Ringold lower mud sequence is $\sim 26 \mathrm{~m}$ thick in well 699-40-36 (south) and slightly more than $11 \mathrm{~m}$ thick in well 699-42-37 north of the TEDF. The lower mud unit consists of clay, silt, and various mixtures of silt, sand, and clay. This unit is particularly important to effluent infiltration and groundwater hydrology beneath TEDF, and is discussed in greater detail in Section 3.2.

The Hanford formation is approximately $30 \mathrm{~m}$ thick beneath the TEDF. The Hanford formation is represented by three facies, in ascending stratigraphic order: 1) lower gravel sequence, 2) sandy sequence, and 3) upper gravel sequence (subdivisions after Lindsey et al. 1992). All of these strata are poorly cemented or non-cemented, and highly permeable compared with the underlying units of the Ringold Formation. A relatively thin veneer of dune sand overlies the Hanford formation to land surface. 


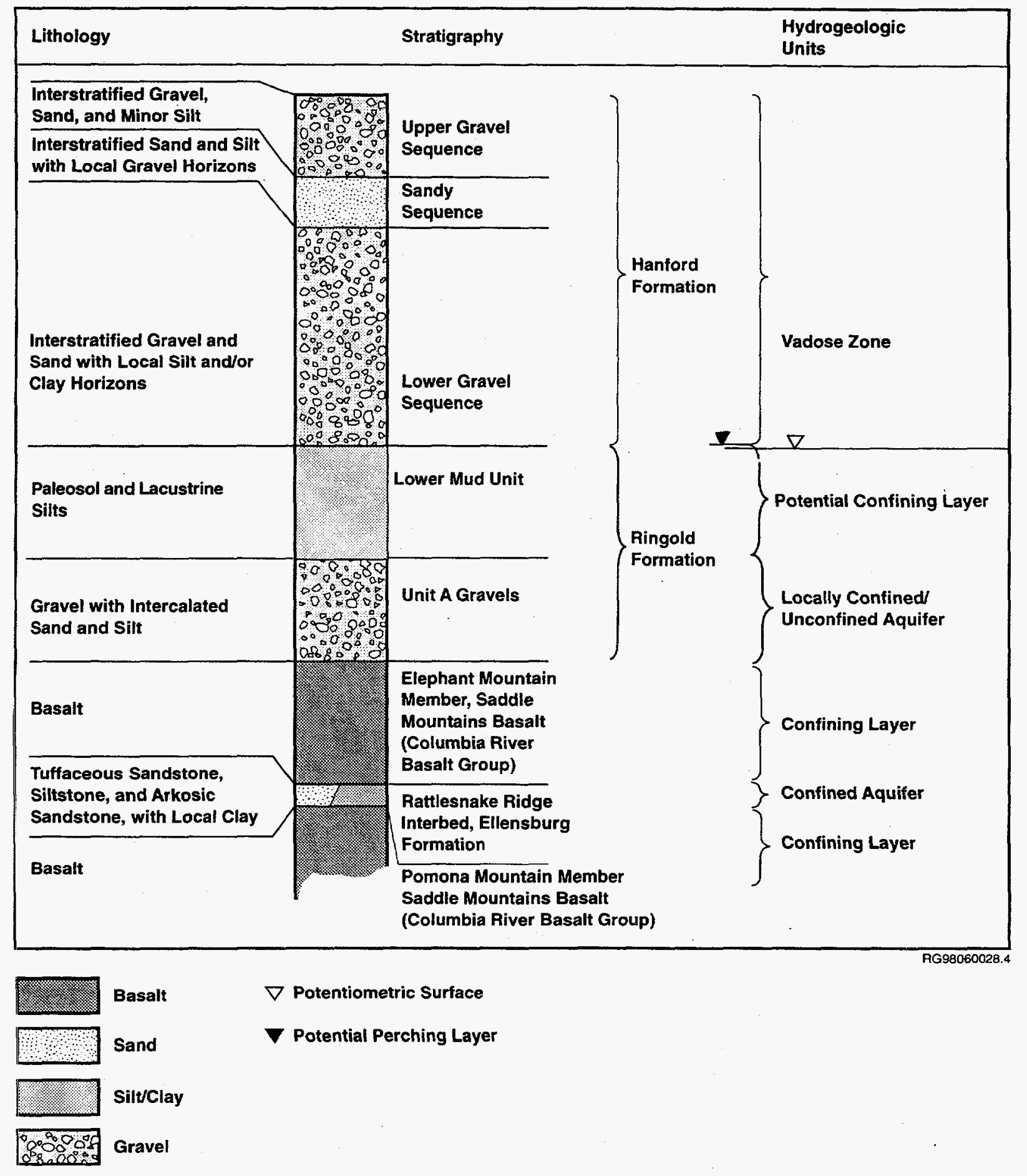

Figure 3.1. Representative Stratigraphic Column for the TEDF Area 


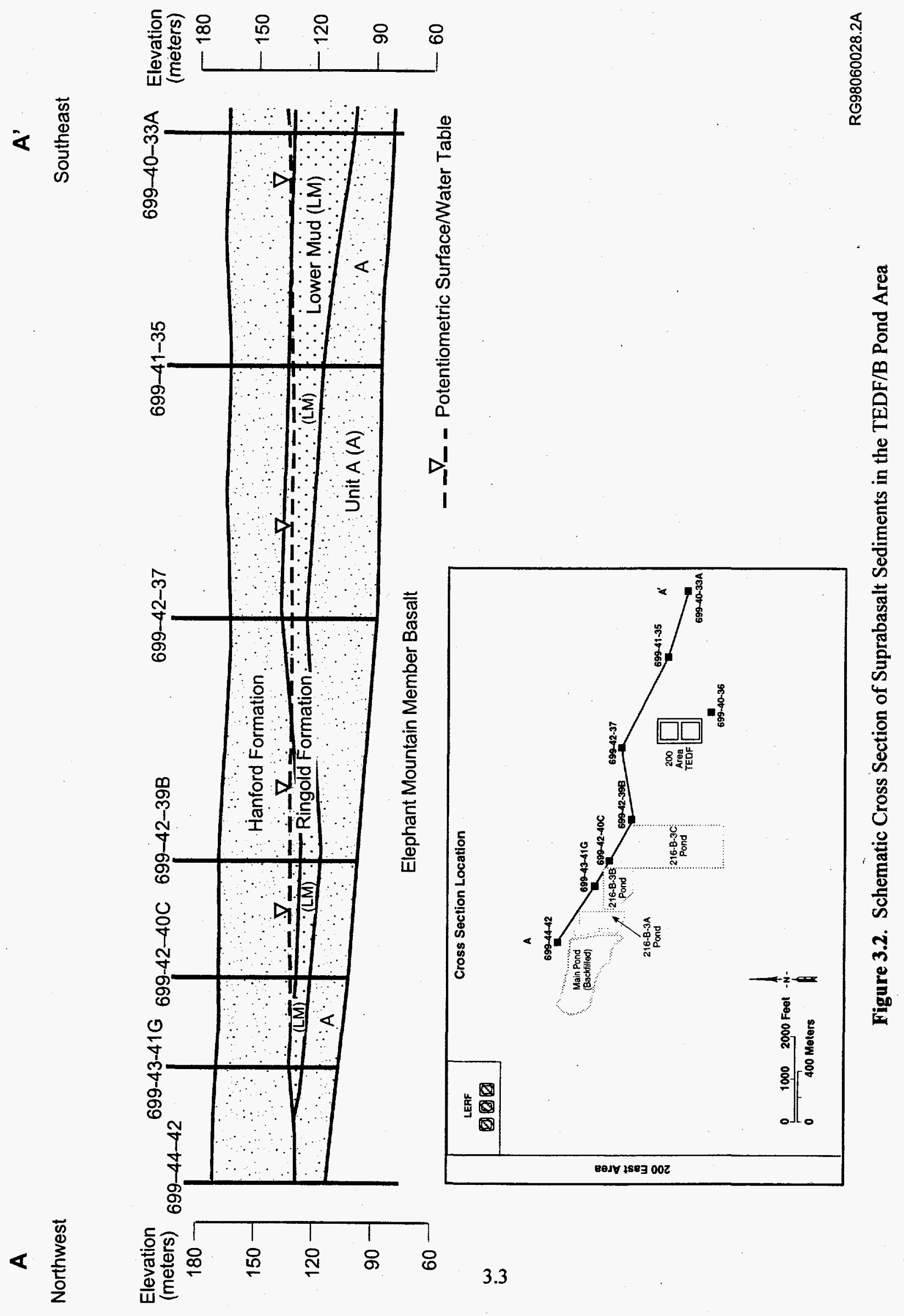




\subsection{Groundwater Hydrology}

The uppermost aquifer beneath the TEDF occurs primarily within sediments of the Ringold Formation, with the Hanford formation comprising the vadose zone. The Columbia River Basalt Group acts as the regional lower boundary for the uppermost unconfined aquifer. Although generally unconfined across the Hanford Site, drilling data and hydrologic tests (Davis et al. 1993) indicate that the uppermost aquifer is under confining pressure beneath the TEDF. The degree of confinement apparently increases gradationally from an unconfined condition near the main pond of the B Pond System to progressively more confined in south and southeasterly directions. Artesian head recorded during well drilling ranged from $\sim 8.5 \mathrm{~m}$ in upgradient well $699-42-37$ to $\sim 25 \mathrm{~m}$ in downgradient well $699-40-36$. This artesian condition was observed in each of the three wells upon penetration of the Ringold lower mud unit. Perched groundwater was encountered during the drilling of well 699-40-36 0.3 $\mathrm{m}$ above the Hanford formation contact with the Ringold lower mud unit.

The confined condition of the aquifer beneath the TEDF is attributed to the presence of the Ringold lower mud unit and its low degree of permeability. An interpretation of the distribution and thickness of this stratum in the vicinity of the TEDF is shown in Figure 3.3. This $11-26 \mathrm{~m}$-thick stratum of finegrained sediment constitutes an effective aquitard and potential perching horizon. Saturated hydraulic conductivity $\left(\mathrm{K}_{\mathrm{s}}\right)$ averaged $5.5 \mathrm{E}-07 \mathrm{~cm} \cdot \mathrm{sec}^{-1}$ in five samples of the lower mud unit taken from the TEDF wells during drilling and testing. One lower mud $\mathrm{K}_{\mathrm{s}}$ was estimated at $7.5 \mathrm{E}-09 \mathrm{~cm} \cdot \mathrm{sec}^{-1}$. In contrast, samples from the superjacent Hanford formation produced $\mathrm{K}_{\mathrm{s}}$ estimates as high as $1.3 \mathrm{E}-01 \mathrm{~cm} \cdot \mathrm{sec}^{-1}$ (Davis et al. 1993). The implications of these conditions for TEDF operation and groundwater monitoring are discussed in Sections 3.3 and 5.0.

As illustrated in Figures 3.1 and 3.2, the potentiometric surface nearly coincides with the upper surface of the Ringold lower mud unit. Figure 3.4 is the potentiometric map for the uppermost aquifer, in the vicinity of TEDF, for June 1997. The hydraulic head in this region is dominated by the hydraulic mound generated from past discharges to the nearby B Pond System. This mound has been subsiding since at least the late 1980 s when discharges to the B Pond System were greatly reduced. This subsidence is reflected in wells throughout the area (see Barnett and Chou 1998) and is apparent in the hydrographs of the three TEDF wells (Figure 3.5). Water level decline in the TEDF wells has noticeably accelerated since mid 1996, in conjunction with reduced or redirected discharges to the B Pond System. Other nearby wells monitoring the B Pond facility reflect similar patterns of decline. Abrupt changes in water levels occur locally over short lateral distances in an area $\sim 1.5$ to $2.0 \mathrm{~km}$ east of TEDF in the vicinity of a geologic structure known as the May Junction fault (Figure 3.4). This feature may locally constrain groundwater movement to the east, and is discussed further in Sections 3.4, 3.5, and 5.0.

Vertical hydraulic potential between the uppermost aquifer in the Ringold Formation and the upperbasalt confined aquifer system near the TEDF is shown to be downwardly directed by Spane and Webber (1995), but very near the interpreted boundary between upward and downward gradients between these aquifers (Figure 3.6). Were it not for the waning influence of the hydraulic mound from the B Pond System, the vertical hydraulic gradient between these aquifers may be upwardly directed farther west than what is shown in Figure 3.6. This is supported by the diminishing differences in water levels between 


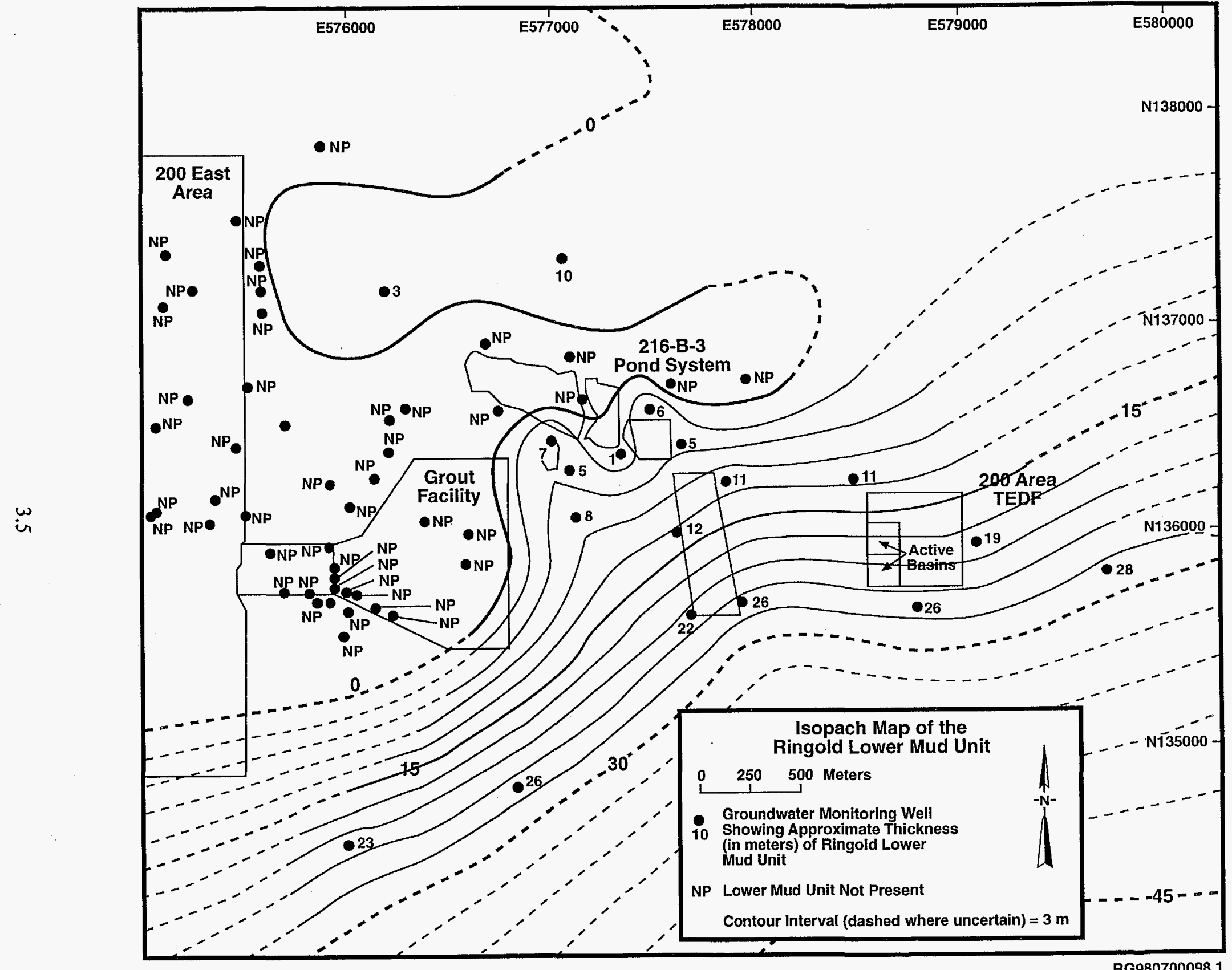

Figure 3.3. An Interpretation of Thickness and Distribution of the Ringold Lower Mud Unit (modified from Davis et al. 1993) 


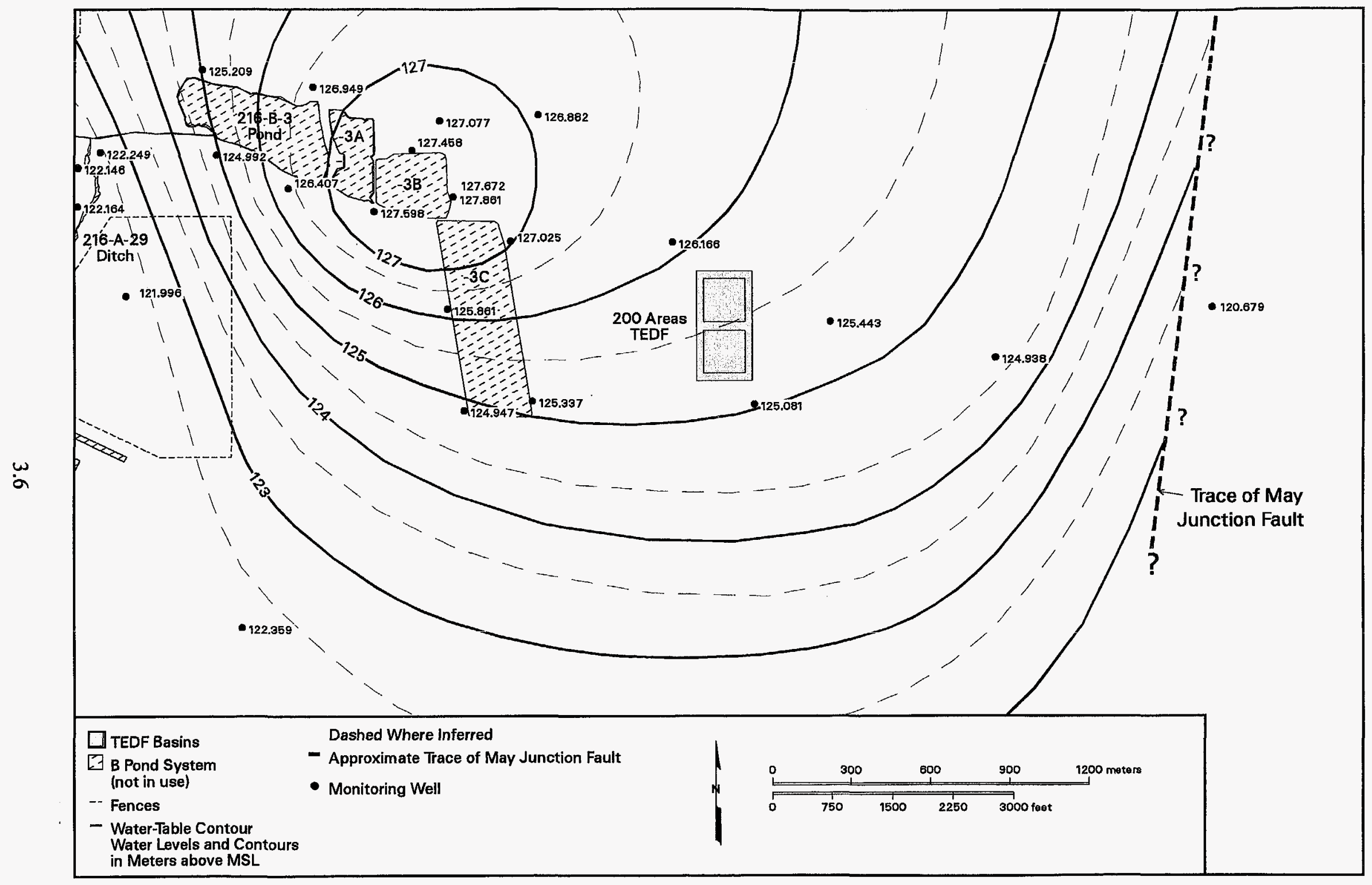

canbar98002 Septembar 09, 1998 10:13 AM

Figure 3.4. Potentiometric Surface in the Vicinity of the TEDF, June 1997 


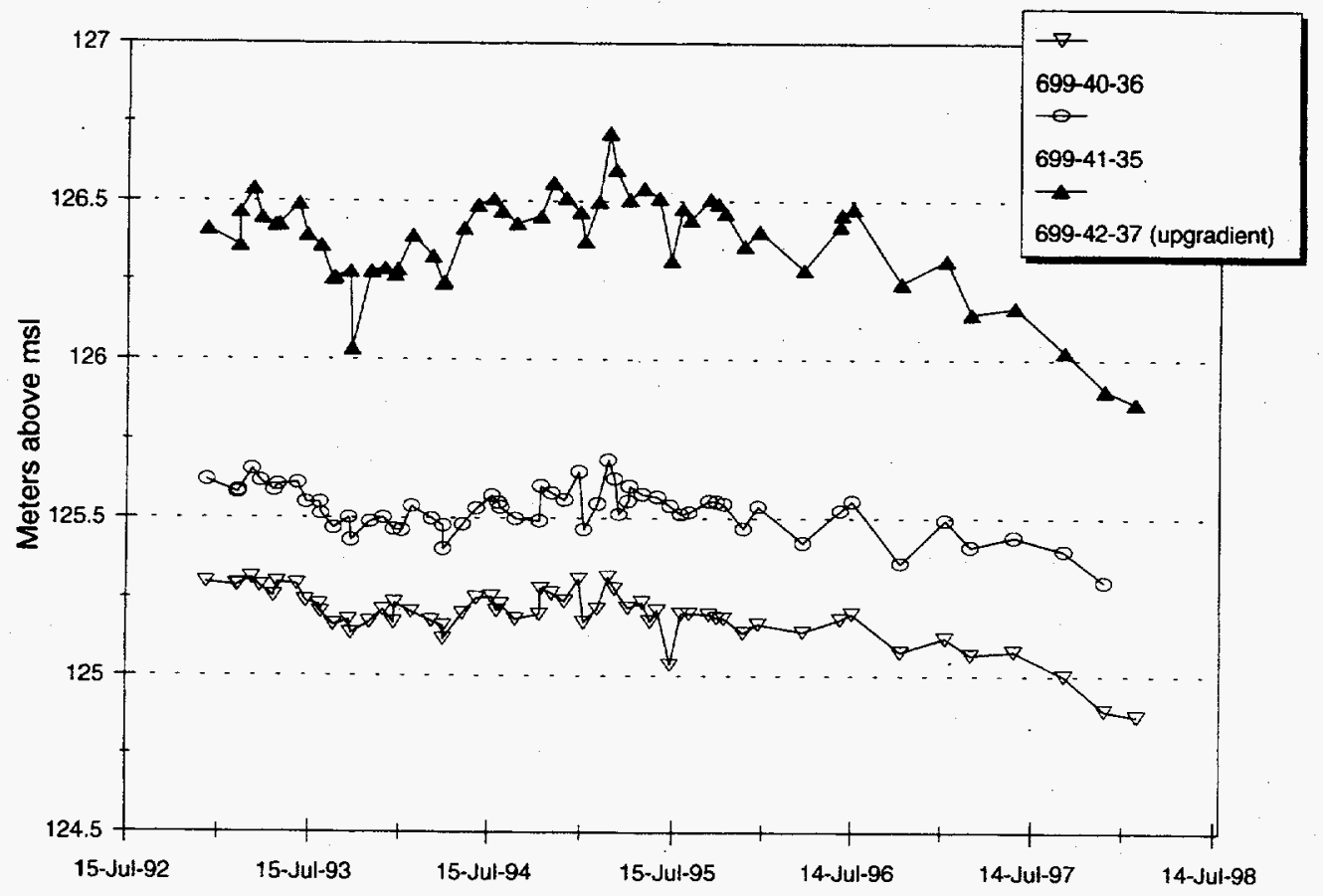

Figure 3.5. Hydrographs of TEDF Groundwater Monitoring Wells

well 699-42-40C, screened in the confined Rattlesnake Ridge Interbed (RRI) of the basalt confined aquifer system, and wells in the same vicinity screened in the regionally-unconfined (uppermost) aquifer (Figure 3.7). These wells are located near the 216-B-3A pond, $\sim 1 \mathrm{~km}$ northwest of the TEDF (refer to Figure 1.3). Hydraulic head in the unconfined system appears to be approaching the head value in the confined system, as represented by well $699-42-40 \mathrm{C}$. Head in well $699-43-41 \mathrm{G}$ has declined nearly to that in the confined aquifer well.

Groundwater velocity in the aquifer beneath the TEDF was calculated using the Darcy equation and estimates of effective porosity and hydraulic conductivity, from lithologic samples and hydrologic tests. By this method, average linear flow velocity was estimated to be from 0.03 to $0.6 \mathrm{~m} \cdot$ day $^{-1}$ in the Ringold Formation Unit A (Barnett et al. 1995). Estimates based on the tracking of contaminant plume movement suggest average linear flow velocities of 0.2 to $2.7 \mathrm{~m} \cdot$ day $^{-1}$ in the general vicinity of the TEDF and 200 East Area (Freshley and Graham 1988; Freshley and Thorne 1992). However, these estimates are averages over a large region within which groundwater flows in the more-permeable Hanford formation. Therefore, such estimates may be too high when compared with values specifically for TEDF. Contouring of hydraulic head in this region (Figure 3.4 ) has consistently indicated southeasterly groundwater flow beneath the facility. 


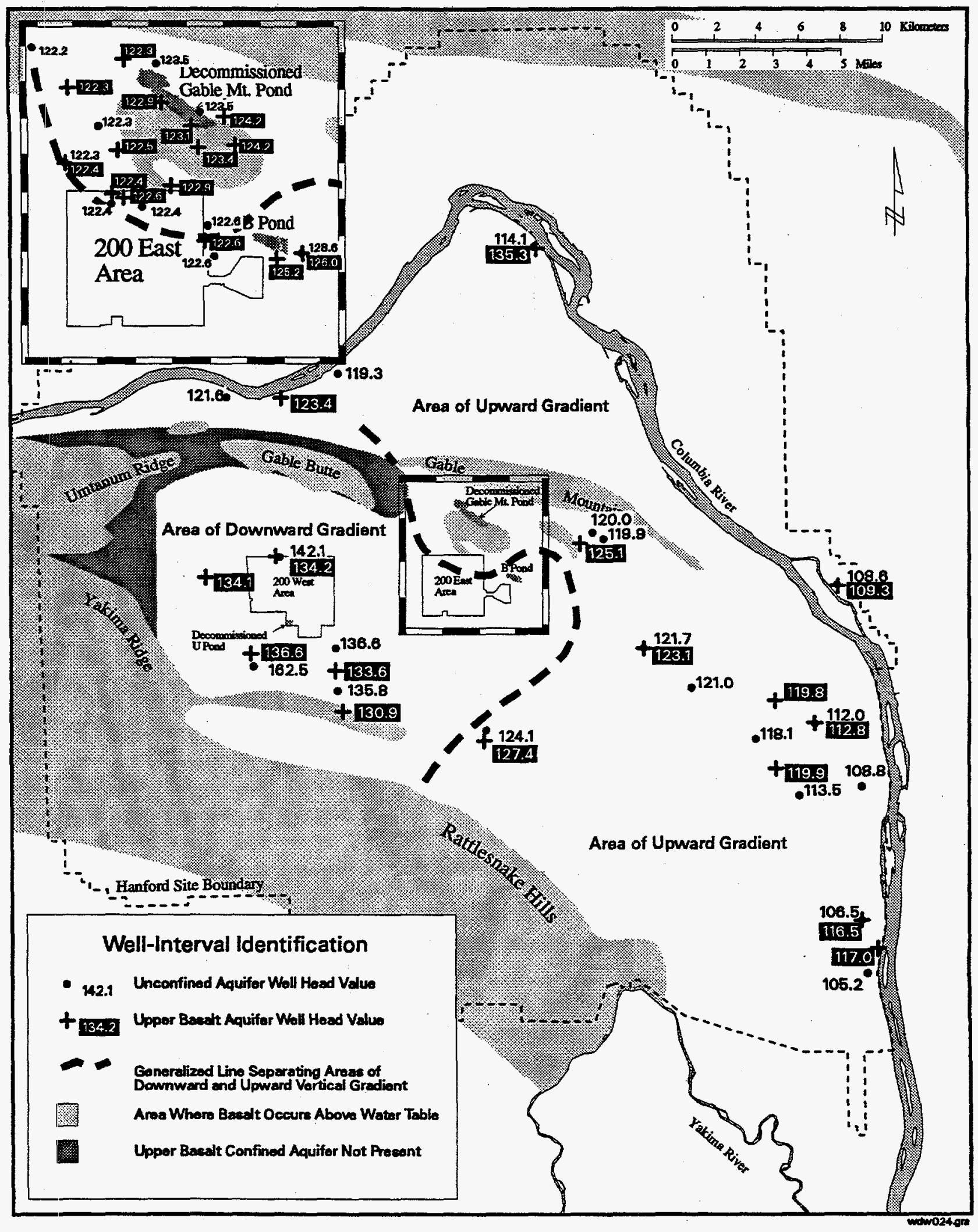

Figure 3.6. Comparison of Observed Hydraulic Heads for the Upper Basalt Confined and Overlying Unconfined Aquifer Systems (Spane and Webber 1995) 


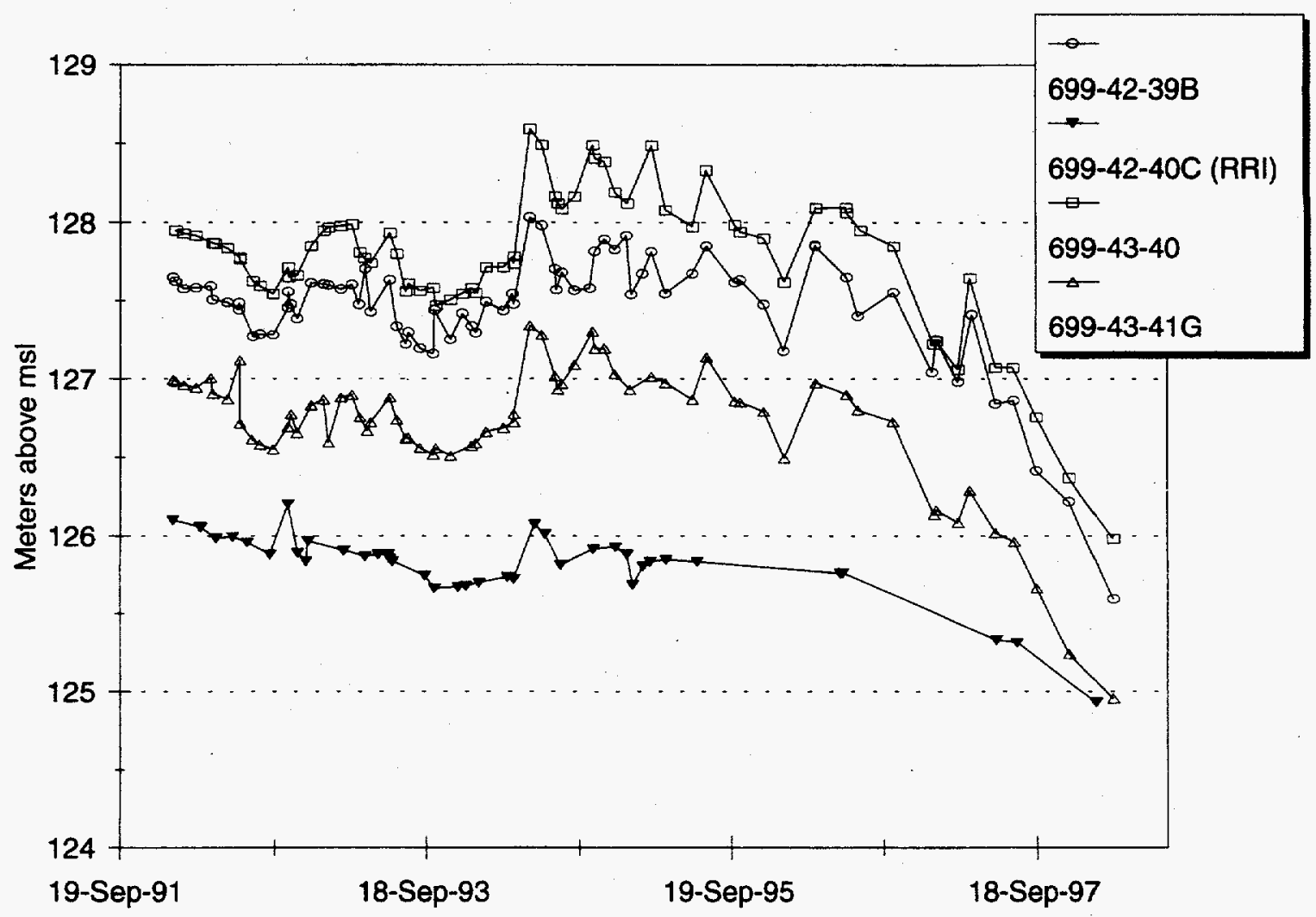

Figure 3.7. Composite Hydrograph of Well $699-42-40 \mathrm{C}$ in the Rattlesnake Ridge Interbed (RRI) of the Upper Basalt Confined Aquifer System and Nearby Wells Completed in the Unconfined Aquifer System

\subsection{Monitoring Well Locations}

When the three facility wells (699-40-36, 699-41-35, 699-42-37) were drilled, it was discovered that the Ringold Formation lower mud unit formed an essentially impermeable layer at the base of the vadose zone, and that this unit was also a confining horizon for the uppermost aquifer beneath the TEDF (see discussion in Section 3.2). Provisions were discussed for installation of additional monitoring points should such a layer be discovered during well installation (Davis and Delaney 1992). However, after consultation with regulators, it was decided that the existing, uppermost aquifer was the correct point of compliance for groundwater, and that the lower mud unit would serve as an additional protective feature for the uppermost aquifer. Monitoring groundwater in this aquifer would help confirm the integrity of the lower mud unit. Hence, these wells are screened below the Ringold Formation lower mud confining unit and monitor groundwater in the upper portion of the Ringold Formation Unit A gravel. Because the TEDF is located hydraulically downgradient of the B Pond System, an upgradient well and two downgradient wells were selected to differentiate the effects of TEDF operation from the potential effects of B Pond System operations. 


\subsection{Summary of Groundwater Modeling Results}

Three groundwater numerical simulations were conducted for the TEDF prior to the beginning of operation. The first model was applied by McMahon, reported in Davis (1992), as part of the siteselection process to evaluate four TEDF candidate locations on the Hanford Site. McMahon (in Davis 1993) later applied a different code to simulate hydrologic conditions produced by the TEDF using different scenarios of wastewater discharge rates to the facility and the nearby 216-B-3 Pond System. Collard, in Barnett et al. (1995), modeled flow and transport of TEDF constituents of concern using attenuation and dilution factors. This section summarizes the salient results of these simulations.

\subsubsection{Groundwater Flow Modeling}

1992. As part of the final site-selection process for the TEDF, McMahon (in Davis 1992) used MODular three-dimensional difference groundwater FLOW model (MODFLOW) to estimate the hydrologic effects of TEDF operation at four locations on the Hanford Site, including the location east of the $B$ Pond System where the facility now resides. Two scenarios of discharge rates were applied $(5,670$ and $56,700 \mathrm{~L} / \mathrm{min}$ [1,500 and 15,000 gpm]). The model consisted of three layers: Hanford formation, finegrained Ringold Formation (the lower mud unit), and coarse-grained Ringold Formation, with the lower boundary of the model at the basalt surface. Two alternate values for hydraulic conductivities were used in both the Hanford formation $(1,000 \mathrm{ft} / \mathrm{d}$ and $10,000 \mathrm{ft} / \mathrm{d})$ and the fine-grained Ringold Formation $(0.1 \mathrm{ft} / \mathrm{d}$ and $1.0 \mathrm{ft} / \mathrm{d})$, but only one value was applied to the coarse-grained Ringold Formation ( $5.0 \mathrm{ft} / \mathrm{d}$ ). Sensitivity analyses indicated that changing hydraulic conductivities of the Hanford formation resulted in the largest differences in modeling results.

The higher assumed value for hydraulic conductivity in the Hanford formation (10,000 $\mathrm{ft} / \mathrm{d})$ coupled with the lowest assumed discharge rate $(5,670 \mathrm{~L} / \mathrm{min}[1,500 \mathrm{gpm}])$ resulted in a barely perceptible simulated groundwater mound beneath the facility. Conversely, when the lower value for hydraulic conductivity $(1,000 \mathrm{ft} / \mathrm{d})$ was combined with the highest discharge scenario $(56,700 \mathrm{~L} / \mathrm{min}$ [15,000 gpm]), the simulation produced a groundwater mound approximately $3 \mathrm{~m}$ high beneath the TEDF in the uppermost aquifer. Results indicated that groundwater mounding would occur beneath and north of the TEDF, and that this mound "would tend to block flow toward the Columbia River from the B Pond Complex...". It was this expectation of mounding, and the consequent beneficial blocking of potential contaminant plumes from the 200 East Area and vicinity from reaching the Columbia River, that contributed to the selection of the current TEDF site. Steady-state flow conditions were achieved at 2 years for the low discharge/high hydraulic conductivity scenario, and 14 years for the high discharge/low hydraulic conductivity scenario.

1993. McMahon, in Davis et al. (1993), used the Variably Saturated Analysis Model in Three Dimensions with Preconditioned Conjugate Gradient Matrix Solvers (VAM3DCG) finite element code (developed by HydroGeoLogic Inc., Herndon, Virginia) to estimate travel times of TEDF effluent to the Columbia River within a 40 -year simulation period ( 30 years of operation and 10 years of reequilibration). The modeled area covered 17,200 hectares mostly east of the 200 East Area, including a geologic structure $\sim 1.5 \mathrm{~km}$ east of TEDF known as the May Junction fault (see Figure 3.3). McMahon assumed this structure to be a mechanism for hydraulically connecting the confined (regionally unconfined) aquifer 
of the Ringold Formation unit $A$, west of the fault, to the gravels of the Hanford formation east of the fault. Evidence for this relationship was cited as the observation that no sharp change in water levels in wells is noted across the trace of the fault and the hydraulic mound from the B Pond System appeared to be unaltered across this area. McMahon simulated four scenarios - a combination of two average annual discharge rates at TEDF, 2,270 and 8,700 L/min (600 and 2,300 gpm), and two average combined annual discharge rates at the 3B and 3C expansion ponds of the B Pond System; 265 and $795 \mathrm{~L} / \mathrm{min}$ (70 and $210 \mathrm{gpm}$ ). In reality, discharges to the expansion ponds were permanently discontinued in August 1997.

Results from the four simulations produced a relatively narrow range of effluent travel times from the TEDF to the Columbia River; 8 to 9.7 years. However, the scenarios using the higher discharge rate to the TEDF $(8,700 \mathrm{~L} / \mathrm{min}[2,300 \mathrm{gpm}])$ resulted in a substantially larger hydraulic mound in the area of the facility than did the lower discharge estimate $(2,270 \mathrm{~L} / \mathrm{min}[600 \mathrm{gpm}])$. The larger discharge scenario also predicted a large hydraulic mound would develop in the unconfined aquifer just north of the TEDF, particularly in the Hanford formation. The lower discharge estimate produced a barely perceptible mound. Discharges of 265 to $795 \mathrm{~L} / \mathrm{min}$ ( 70 to $210 \mathrm{gpm}$ ) to the B Pond System had no material effect on the mound size or travel times. Ten years after simulated discharges to the TEDF ceased, a small mound still remained with the higher discharge scenario. Within the anticipated range of long-term (permitted) rates of discharge (at that time $\sim 2,820 \mathrm{~L} / \mathrm{min}[745 \mathrm{gpm}]$ ), travel time to the Columbia River was predicted to be 9.6 years (current permitted rates of discharge are now 4,500 L/min $(1,200 \mathrm{gpm})$ (see Sections 1.2 and 1.3). The model also predicted that the existing groundwater mound beneath the B Pond System (see Figure 3.2) would become unrecognizable within 10 years of the beginning of TEDF operations.

\subsubsection{Contaminant Transport Modeling}

Collard, in Barnett et al. (1995), combined the low-volume scenario (2,270 L/min [600 gpm]) of the McMahon VAM3DCG model (Davis et al. 1993) with constituent transport information to predict travel of potential contaminants from the TEDF under steady-state conditions. Using empirically derived coefficients of distribution $\left(\mathrm{K}_{d}\right)$ and constituent half-lives, Collard generated Factors of Attenuation and Dilution Efficacy (FADE) for several constituents of concern at the TEDF, including metals and organic compounds. If no estimate of $\mathrm{K}_{d}$ was available a factor of " 0 " was assigned to be conservative. An enhancement routine was used to accelerate the simulated movement of effluent through the Ringold lower mud unit to the uppermost aquifer. This enhancement also introduced highly conservative FADE values to the model. Thus, Collard states that estimates of FADE values represent a "worst-case" scenario for movement of contamination in the aquifer, and the vadose-zone scenario is described as "prudently conservative."

Modeled observation points, for generating FADE values in the vadose zone and aquifer, were selected at $200-\mathrm{m}$ intervals east and south of the facility, and at $282-\mathrm{m}$ intervals southeast of the facility. The observation point furthest from the facility was $564 \mathrm{~m}$ to the southeast. The observation points also sampled vertical locations at the top of the vadose zone (Hanford formation), the bottom of the vadose zone (in the Hanford formation near its contact with the Ringold lower mud), the top of the uppermost aquifer (in the Ringold unit $A$, just below the lower mud unit), and the bottom of the uppermost aquifer

in the Ringold unit $A$ (the bottom of the model domain). With $K_{d}$ values ranging from near $0 \mathrm{~mL} \cdot \mathrm{g}^{-1}$ for very conservative species (e.g., sulfate, chromium-VI) to $30 \mathrm{~mL} \cdot \mathrm{g}^{-1}$ (e.g., iron, manganese), Collard 
predicted breakthrough (the point in the system at which $0.1 \%$ of the initial concentration is observed) times to the bottom of the vadose zone from $<1$ year to $>2,000$ years, depending on the conservativeness of the species and horizontal distance from the TEDF. Breakthrough times for the top of the aquifer ranged from 42 years for the most conservative species at an observation point closest to the facility to 7,200 years for a high $\mathrm{K}_{d}$ species $200 \mathrm{~m}$ downgradient of the facility. In summation, Collard states that FADE values for the Hanford formation provides "significant" protection of the uppermost aquifer, and notes that the FADEs would likely be orders of magnitude larger if transient, instead of steady-state, conditions were applied. In Collard's assessment, very little risk is posed to the aquifer by contaminant release from the facility, even in quantities far exceeding those reasonably expected.

\subsection{Discussion of Hydrogeology and Modeling Results}

Drilling and hydrologic testing in the area surrounding the TEDF indicate that the Ringold Formation lower mud unit is a laterally consistent, effective aquitard/confining unit in this region, and that a stark contrast in hydraulic conductivity exists between this unit and the extremely permeable overlying Hanford formation sediments. Groundwater found in the Hanford formation in this area is likely to be very limited and occurs only as thin, discontinuous perched layers. It is possible that even the perched water discovered in well 699-40-36 is a remnant of earlier B Pond discharges that became isolated in a local depression on the lower mud surface as the B Pond hydraulic mound subsided. All evidence suggests that infiltrating discharges from TEDF will impound at the Hanford formation/lower mud contact and spread laterally in the Hanford formation. The high hydraulic conductivity of the Hanford formation will limit the size of any groundwater mound beneath the facility, and flow of this effluent will be dominantly south to southeast down the structural trend of the lower mud surface.

Groundwater flow modeling by McMahon in Davis (1992) and Davis et al. (1993) predicted that a groundwater mound would develop in the uppermost aquifer beneath TEDF for discharges of $>8,700 \mathrm{~L} / \mathrm{min}(2,300 \mathrm{gpm})$, especially if lower estimates of hydraulic conductivity for the Hanford formation were used in the model. Conversely, very limited mounding was predicted if TEDF discharges of $<5,670 \mathrm{~L} / \mathrm{min}(1,500 \mathrm{gpm})$ were applied with high hydraulic conductivities in the Hanford formation. In fact, discharges have averaged only $1,500 \mathrm{~L} / \mathrm{min}(400 \mathrm{gpm})$ since operation began in 1995 , and only $\sim 3,000 \mathrm{~L} / \mathrm{min}(800 \mathrm{gpm})$ during the more voluminous discharges since September 1997 (see Figure 1.4). The lower actual discharges combined with high hydraulic conductivity of the Hanford formation (see Section 3.2), and the impermeable nature of the lower mud unit have probably prevented significant mounding beneath TEDF. Modeling also indicated that hydraulic potential in the uppermost aquifer would be affected by TEDF discharges. Thus far, however, hydrographs of the three TEDF monitoring wells (completed below the lower mud unit) reflect a continuing and accelerating subsidence of the hydraulic mound from the B Pond facility, with no apparent response to TEDF operations.

Eastward movement of groundwater in the uppermost aquifer was assumed to be mostly unaffected by the May Junction fault. However, recent analysis of stratigraphic and hydrologic relationships in this region suggest that hydraulic head values differ significantly on opposite sides of the fault locally (see far 
right on Figure 3.4), and that this structure may constrain eastward groundwater flow. Thus, groundwater movement from the Ringold Formation to the Hanford formation in this area may not occur unimpeded as previously anticipated.

Summary. Hydrogeologic data suggest that the uppermost aquifer beneath the TEDF is currently unaffected by discharges from the facility after $3+$ years of operation. Hydrographs of wells completed in the aquifer have not responded to the addition of effluent to the overlying vadose zone, apparently as a consequence of the intervening lower mud unit. The lower mud unit appears to be of sufficient thickness and continuity to prevent TEDF effluent from readily reaching the aquifer in the vicinity of the facility. The possibility remains that TEDF effluent may eventually reach the aquifer via discontinuities in the lower mud unit $\sim 0.5 \mathrm{~km}$ north of TEDF, or at a significant distance south of the facility. Modeling of contaminant transport from the TEDF indicates that using the most conservative assumptions, the potential for contamination reaching the uppermost aquifer is virtually nil. Retardation of non-conservative species in the Hanford formation alone is significant, and greatly increased by the lower mud unit. Additionally, the lower mud unit appears to form an effective hydrologic barrier between the Hanford formation (vadose zone) and the uppermost aquifer and would thus further retard downward migration of any potential contamination.

Hydrographs of wells in the vicinity of the B Pond hydraulic mound indicate that the historically downward hydraulic gradient between the unconfined aquifer and the upper basalt confined aquifer is diminishing and nearly reversed (upwardly directed gradient) in some areas. It is possible that an upward potential already exists between the confined and unconfined systems further southeast, in the vicinity of the TEDF. As this trend continues, downward movement of water introduced to the unconfined aquifer will be increasingly impeded by the upward gradient. This condition would add a protective factor to the uppermost aquifer in the vicinity of TEDF, tending to prevent downward migration of any potentially entrained contaminants. 


\subsection{Summary of Groundwater Geochemistry}

Since 1992, over 15,000 field and laboratory analytical results have been produced from the three groundwater monitoring wells at the TEDF. Groundwater monitoring began under the aegis of the RCRA program for the nearby 216-B-3 Pond System, and were included in that facility's network for 2+ years. When groundwater monitoring parameters were established by the SWDP, a new list of constituents was used, then later reduced by amendment to the SWDP requirements, to reflect a more appropriate focus of analyses (see Section 2.2 and Appendix B). Throughout this period, samples have been, and are currently collected quarterly. This section summarizes the results of comprehensive groundwater analyses from the TEDF wells, with emphasis on parameters of particular concern for the TEDF. Major ion chemistry is also examined to gain additional insight into the geochemical character of the aquifer in the vicinity of the facility.

\subsection{Synopsis of Analytical Results}

Table B. 2 represents a comprehensive list of constituents and parameters designed to characterize groundwater chemistry in the uppermost aquifer at the TEDF site. The list includes the Appendix IX constituents, and other parameters of site-specific or Hanford-specific interest. Accompanying most of these parameters is a corresponding PQL (see Section 2.3). Groundwater from the three TEDF wells was analyzed for constituents on this list for 3 consecutive quarters, as required for background screening in the SWDP (Barnett et al. 1995). Tables 4.1 through 4.3 list results for constituents that have yielded at least one result above the PQL, from the beginning-of monitoring through March 1998. The table lists the number of analyses evaluated, the average value, standard deviation, and maximum result. Many of the maximum results for constituents occur as isolated outliers, and are thus labeled as "suspect result" in the comments column of the tables. The salient aspects of TEDF groundwater geochemical results are discussed here, particularly as they compare with Hanford sitewide background values in groundwater (Johnson 1993) and analytical results from groundwater monitoring wells in the nearby B Pond System (e.g., see Barnett and Teel 1997).

Average values for dissolved metals in groundwater samples from TEDF wells appear to be mostly below Hanford Site provisional background determined by Johnson (1993). Exceptions are manganese and sodium in all three wells, barium in well 699-41-35, and uranium in wells 699-41-35 and 699-42-37. Some metals, notably chromium, manganese, and iron, have exceeded primary or secondary Drinking Water Standards (DWS) in all three wells in either filtered or unfiltered samples. Elevated levels of these metals have been attributed to well construction materials and natural aquifer conditions across the Hanford Site (Johnson 1993). Upgradient well 699-42-37 has the greatest number of highest averages for metals between the three TEDF wells.

Anions are also notably higher in well 699-42-37 than in the two downgradient wells. The average result for nitrate is roughly an order of magnitude higher in this well than in 699-41-35 and 699-40-36. Likewise, the average for sulfate is 4 to 5 times higher in well 699-42-37 than in the two downgradient 
Table 4.1. Constituents from the Original TEDF Analyte List with at Least One Result Exceeding PQL in Well 699-40-36

\begin{tabular}{|c|c|c|c|c|c|}
\hline Constituent & $\mathrm{n}^{(\mathbf{a})}$ & mean $^{(b)}$ & $\mathrm{sd}^{(\mathrm{b})}$ & Maximum Result ${ }^{(b)}$ & Comments \\
\hline Bis(2-hexylethyl) phthalate & 5 & 2.2 & 2.2 & 6.0 & $\begin{array}{l}\text { Estimated value-common lab } \\
\text { contaminant }\end{array}$ \\
\hline Butylbenzyl phthalate & 1 & -- & - & 17.00 & \\
\hline \multirow[t]{2}{*}{ Aluminum } & $F=5$ & 82 & 128.4 & 310 & \multirow{2}{*}{$\begin{array}{l}\text { Unfiltered max. is suspect } \\
\text { result }\end{array}$} \\
\hline & $\mathrm{U}=20$ & 1600.9 & 5982.7 & 27,000 & \\
\hline \multirow[t]{2}{*}{ Barium } & $F=19$ & 66.8 & 5.4 & 80 & \\
\hline & $\mathrm{U}=\mathbf{3 0}$ & 77.0 & 44.3 & 310 & \\
\hline \multirow[t]{2}{*}{ Calcium } & $F=17$ & 15,182 & 1,013 & 17,400 & \\
\hline & $\mathrm{U}=\mathbf{2 8}$ & 15,782 & 1,956 & 24,000 & \\
\hline \multirow[t]{2}{*}{ Chromium } & $\mathrm{F}=8$ & 5.6 & 4.4 & 8.4 & \\
\hline & $\mathrm{U}=\mathbf{2 8}$ & 17.3 & 30.1 & 120 & \\
\hline \multirow[t]{2}{*}{ Iron } & $F=12$ & 49 & 19 & 80 & \multirow{2}{*}{$\begin{array}{l}\text { Unfiltered max. is suspect } \\
\text { result }\end{array}$} \\
\hline & $\mathrm{U}=26$ & 369 & 340 & 38,000 & \\
\hline \multirow[t]{2}{*}{ Magnesium } & $F=17$ & 5,345 & 265 & 5,860 & \multirow{2}{*}{$\begin{array}{l}\text { Unfiltered max. is suspect } \\
\text { result }\end{array}$} \\
\hline & $\mathrm{U}=27$ & 5,440 & 278 & 13,000 & \\
\hline \multirow[t]{2}{*}{ Manganese } & $F=22$ & 66.0 & 42.4 & 160 & \multirow{2}{*}{$\begin{array}{l}\text { Unfiltered max. is suspect } \\
\text { result }\end{array}$} \\
\hline & $\mathrm{U}=29$ & 92.6 & 138.8 & 780 & \\
\hline \multirow[t]{2}{*}{ Nickel } & $F=0$ & - & -- & -- & \\
\hline & $U=3$ & 63 & 20 & 83 & \\
\hline \multirow[t]{2}{*}{ Potassium } & $F=17$ & 7,702 & 608 & 8,800 & \multirow{2}{*}{$\begin{array}{l}\text { Unfiltered max. is suspect } \\
\text { result }\end{array}$} \\
\hline & $\mathrm{U}=28$ & 7,815 & 997 & 12,000 & \\
\hline \multirow[t]{2}{*}{ Silicon } & $F=10$ & 21,580 & 738 & 25,200 & \multirow{2}{*}{$\begin{array}{l}\text { Unfiltered max. is an estimated } \\
\text { value }\end{array}$} \\
\hline & $\mathrm{U}=\mathbf{2 0}$ & 22,810 & 1,415 & 38,300 & \\
\hline \multirow[t]{2}{*}{ Sodium } & $F=17$ & 46,759 & 2,422 & 54,000 & \\
\hline & $\mathrm{U}=28$ & 46,243 & 1615 & 50,000 & \\
\hline \multirow[t]{2}{*}{ Uranium } & $F=3$ & 3.2 & 0.1 & 3.7 & \\
\hline & $U=19$ & 3.19 & 0.23 & 3.8 & \\
\hline \multirow[t]{2}{*}{ Vanadium } & $F=15$ & 13.9 & 4.6 & 24 & \\
\hline & $\mathrm{U}=24$ & 18 & 15.4 & 87 & \\
\hline \multirow[t]{2}{*}{ Zinc } & $F=10$ & 33.7 & 34 & 97.5 & \\
\hline & $U=25$ & 135.6 & 180.2 & 690 & \\
\hline Ammonia & 3 & 64 & 14 & 80 & "Q" flag \\
\hline Alkalinity & 24 & 144,620 & 4,008 & 153,000 & \\
\hline $\begin{array}{l}\text { Specilic conductance } \\
\text { (conductivity) }\end{array}$ & 97 & 315.3 & 9.4 & 333 & Units in $\mu \mathrm{mhos} / \mathrm{cm}$ \\
\hline Turbidity & 33 & 27.4 & 129.8 & 750 & $\begin{array}{l}\text { In nephelimetric turbidity units } \\
\text { (NTU) }\end{array}$ \\
\hline $\mathrm{pH}$ & 91 & 8.0 & 0.2 & $\begin{aligned} \text { Maximum } & =8.26 \\
\text { Minimum } & =7.34\end{aligned}$ & In $\mathrm{pH}$ units \\
\hline Total dissolved solids & 21 & 206,952 & 21,885 & 242,000 & \\
\hline
\end{tabular}


Table 4.1. (contd)

\begin{tabular}{|c|c|c|c|c|c|}
\hline Constituent & $n^{(\boldsymbol{n})}$ & mean $^{(b)}$ & $\mathbf{s d}^{(b)}$ & Maximum Result ${ }^{(\mathrm{b})}$ & Comments \\
\hline Total organic carbon & 23 & 443 & 367 & 1,820 & \\
\hline Nitrate (includes $\mathrm{N}$ in $\mathrm{NO}_{3}$ ) & 21 & 95 & 86 & 332 & \\
\hline $\mathrm{N}$ in $\mathrm{NO}_{2}$ & 13 & 13 & 8 & 20 & \\
\hline Chloride & 26 & 3,332 & 158 & 3,830 & \\
\hline Sulfate & 26 & 5,666 & 3,522 & 17,000 & \\
\hline Fluoride & 26 & 837 & 175 & 1,200 & \\
\hline Total suspended solids & 8 & 6,750 & 6,408 & 17,000 & \\
\hline Radium-226 & 7 & 0.131 & 0.03 & 0.23 & $\mathrm{pCi} / \mathrm{L}$ \\
\hline Gross alpha & 26 & 3.65 & 3.89 & 21 & $\mathrm{pCi} / \mathrm{L}$ \\
\hline Gross beta & 26 & 8.84 & 6.58 & 36.5 & $\mathrm{pCi} / \mathrm{L}$ \\
\hline Oil and grease & 7 & 9,414 & 14,379 & 41,800 & $\begin{array}{l}\text { See text for explanation of } \\
\text { results }\end{array}$ \\
\hline
\end{tabular}

wells. These higher nitrate and sulfate averages approach average values observed in the nearby B Pond System wells to the immediate northwest (see Figure 1.3 for location). However, anion averages in all three wells are still below provisional backgrounds provided by Johnson (1993). Additional calculations and comparisons of ionic concentrations are presented in Section 4.2.

Few organic constituents have been detected in TEDF wells. Those listed in Tables 4.1 through 4.3 are mostly attributed to common laboratory contaminants, with some exceptions. In early 1993, traces of motor oil or fuel were purportedly observed by field crews on a pump removed from well 699-40-36. Subsequent total oil and grease analyses indicated elevated levels of this constituent in a groundwater sample from this well. When groundwater monitoring began under the SWDP in 1995, initial results for oil and grease were reported as below detection. Later, in the July sampling event for that year, all three wells around the facility showed elevated levels of oil and grease. This constituent remained elevated in these wells (see Tables 4.1, 4.2, and 4.3) until April 1996, whereupon all results fell to below detection and have remained so since. The supposed source of the contamination was never resolved, but was thought to be related to equipment used to remove the pumps from the wells in preparation for in-well hydrologic testing. The pumps were thought to possibly have been contaminated while being handled at the surface, then reinstalled without proper cleaning. However, the coincidence of detections and nondetections in all 3 wells simultaneously raises suspicion over the validity of the analyses or sampling procedures. Analyses of gasoline produced only one result above detection; this occurred in well 699-41-35. These parameters remain on the current list of constituents for groundwater sampling at the TEDF (see Section 2.2). 
Table 4.2. Constituents from the Original TEDF Analyte List with at Least One Result Exceeding PQL in Well 699-41-35

\begin{tabular}{|c|c|c|c|c|c|}
\hline Constituent & $\mathrm{n}^{(\mathrm{a})}$ & mean $^{(b)}$ & $\mathrm{sd}^{(\mathrm{b})}$ & Maximum Result $^{(b)}$ & Comments \\
\hline Bis(2-hexylethyl) phthalate & 6 & 25.3 & 36.9 & 100.00 & $\begin{array}{l}\text { Includes estimated values; } \\
\text { common lab contaminant }\end{array}$ \\
\hline Butylbenzyl phthalate & 1 . & -- & - & 1.0 & Estimated value \\
\hline \multirow[t]{2}{*}{ Aluminum } & $F=5$ & 59.9 & 79.5 & 200 & \\
\hline & $\mathrm{U}=9$ & 543.8 & 986.1 & 2,800 & \\
\hline \multirow[t]{2}{*}{ Barium } & $F=18$ & 139.4 & 13.1 & 170 & \\
\hline & $\mathrm{U}=30$ & 143.5 & 7.6 & 154 & \\
\hline \multirow[t]{2}{*}{ Calcium } & $\mathrm{F}=18$ & 19,241 & 1,326 & 23,000 & \multirow{2}{*}{$\begin{array}{l}\text { Unfiltered max. is estimated } \\
\text { value }\end{array}$} \\
\hline & $U=28$ & 19,028 & 811 & 20,300 & \\
\hline \multirow[t]{2}{*}{ Chromium } & $F=6$ & 4.8 & 2.4 & 8.6 & \\
\hline & $\mathrm{U}=\mathbf{2 5}$ & 17.0 & 26.8 & 110 & \\
\hline \multirow[t]{2}{*}{ Iron } & $F=10$ & 74 & 116 & 400 & \multirow[t]{2}{*}{ Filtered max. is suspect result } \\
\hline & $\mathrm{U}=\mathbf{2 3}$ & 409 & 996 . & 4,100 & \\
\hline \multirow[t]{2}{*}{ Magnesium } & $\mathbf{F}=17$ & 7,021 & 473 & 8300 & \\
\hline & $U=29$ & 7,068 & 225 & 7,390 & \\
\hline \multirow[t]{2}{*}{ Manganese } & $F=21$ & 69.6 & 51.2 & 170 & \\
\hline & $\mathrm{U}=31$ & 65.2 & 54.4 & 210 & \\
\hline \multirow[t]{2}{*}{ Nickel } & $F=1$ & 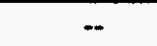 & - & 17 & \\
\hline & $\mathrm{U}=4$ & 36 & 21 & 55 & \\
\hline \multirow[t]{2}{*}{ Potassium } & $F=17$ & 6,424 & 757 & 8,000 & \\
\hline & $U=28$ & 6,422 & 462 & 7,300 & \\
\hline \multirow[t]{2}{*}{ Silicon } & $F=10$ & 19,840 & 677 & 21,900 & \\
\hline & $U=22$ & 21,000 & 1,262 & 23,600 & \\
\hline \multirow[t]{2}{*}{ Sodium } & $F=17$ & 42,235 & 3,159 & 53,000 & \\
\hline & $U=29$ & 42,190 & 1,394 & 47,000 & \\
\hline \multirow[t]{2}{*}{ Uranium } & $F=3$ & 5.13 & 0.21 & 5.8 & \\
\hline & $\mathrm{U}=23$ & 5.02 & 0.38 & 5.8 & \\
\hline \multirow[t]{2}{*}{ Vanadium } & $F=13$ & 9.2 & 3.4 & 15.3 & \\
\hline & $U=15$ & 9.6 & 3.3 & 17 & \\
\hline \multirow[t]{2}{*}{ Zinc } & $F=8$ & 16.0 & 7.9 & 27.3 & \\
\hline & $U=24$ & 29.4 & 33.7 & 150 & \\
\hline Ammonia & 5 & 61 & 32 & 100 & \\
\hline Alkalinity & 25 & 146,760 & 4,772 & 160,000 & \\
\hline $\begin{array}{l}\text { Specific conductance } \\
\text { (conductivity) }\end{array}$ & 98 & 323.3 & 6.8 & 344 & Units in $\mu \mathrm{mhos} / \mathrm{cm}$ \\
\hline Turbidity & 30 & 4.8 & 9.8 & 42 & $\begin{array}{l}\text { In nephelimetric turbidity units } \\
\text { (NTU) }\end{array}$ \\
\hline $\mathrm{pH}$ & 101 & 7.9 & 0.2 & $\begin{array}{l}\text { Maximum }=8.45 \\
\text { Minimum }=7.45\end{array}$ & In $\mathrm{pH}$ units \\
\hline Total dissolved solids & 22 & 203,000 & 18,359 & 263,000 & \\
\hline
\end{tabular}


Table 4.2. (contd)

\begin{tabular}{|c|c|c|c|c|c|}
\hline Constituent & $n^{(2)}$ & mean $^{(b)}$ & $s d^{(b)}$ & Maximum Result ${ }^{(\mathrm{b})}$ & Comments \\
\hline Total organic carbon & 15 & 353 & 305 & 1,120 & \\
\hline Nitrate (includes $\mathrm{N}$ in $\mathrm{NO}_{3}$ ) & 24 & 210 & 116 & 500 & \\
\hline $\mathrm{N}$ in $\mathrm{NO}_{2}$ & 13 & 13 & 9 & 30 & \\
\hline Chloride & 25 & 3,383 & 316 & 4,480 & \\
\hline Sulfate & 27 & 6,643 & 1,007 & 8,800 & \\
\hline Fluoride & 25 & 774 & 148 & 1,100 & \\
\hline Total suspended solids & 6 & 3,333 & 2,582 & 6,000 & \\
\hline Radium-226 & 10 & 0.30 & 0.32 & 1.2 & $\mathrm{pCi} / \mathrm{L}$ \\
\hline Gross alpha & 24 & 4.08 & 1.52 & 7.4 & $\mathrm{pCi} / \mathrm{L}$ \\
\hline Gross beta & 23 & 6.96 & 2.36 & 11.4 & $\mathrm{pCi} / \mathrm{L}$ \\
\hline Oil and grease & 7 & 19,979 & 26,731 & 63,000 & See text for discussion \\
\hline Gasoline & 1 & -- & - & 118,000 & See text for discussion \\
\hline
\end{tabular}

Total trihalomethanes (the sum of $\mathrm{CHCl}_{3}, \mathrm{CHBrCl}_{2}, \mathrm{CHBr}_{2} \mathrm{Cl}$, and $\mathrm{CHBr}_{3}$ ), is the only parameter assigned an early-warning value for groundwater in the SWDP. Thus far, all analytical results for this parameter have been below the PQL $(20 \mu \mathrm{g} / \mathrm{L})$, and hence, well below the early-warning value of $50 \mu \mathrm{g} / \mathrm{L}$.

Of the radionuclides or radionuclide indicators listed in Table B.2, only radium, uranium, gross alpha, and gross beta produced results above contract detection limits (CDL). Uranium occurred above background levels in two wells (see discussion of metals). Gross alpha and gross beta averages fell below background for all wells, but maximum results in each well exceeded gross alpha background, and maximum results for gross beta exceeded background in well 699-40-36. This well displayed coincident events of elevated gross alpha and gross beta in early 1994 (Figure 4.1). Higher-than-average values of gross alpha also occurred during this period in wells 699-41-35 and 699-42-36. Gross beta values appear to generally decrease in all three wells beginning in early 1994. However, no specific alpha (e.g., U or ${ }^{226} \mathrm{Ra}$ ) or beta emitters were identified during the periods of elevated gross alpha and gross beta shown in Figure 4.1. Further, all results for ${ }^{226} \mathrm{Ra}$ and most results for $U$ were below Johnson's (1993) provisional background values for these radionuclides. Problematic detections occurred for ${ }^{125} \mathrm{Sb}(15.2 \pm 14.9 \mathrm{pCi} / \mathrm{L})$ and ${ }^{137} \mathrm{Cs}(7.13 \pm 5.4 \mathrm{pCi} / \mathrm{L})$ during 1993 (prior to TEDF operations), but detections of these radionuclides do not occur with enough frequency to correlate to gross beta results.

Tritium has not been detected in any of 52 analyses that have been performed in the TEDF wells since late 1992. In July of 1998, tritium analyses were performed on groundwater samples from the three wells and TEDF end-of-pipe discharge using low-detection methods. Results for tritium in all three wells were below detection $(<4.41 \mathrm{pCi} / \mathrm{L})$. These levels of tritium activity are considered exceptionally low for 
Table 4.3. Constituents from the Original TEDF Analyte List with at Least One Result Exceeding PQL in Well 699-42-37

\begin{tabular}{|c|c|c|c|c|c|}
\hline Constituent & $\mathrm{n}^{(\mathbf{a})}$ & mean $^{(b)}$ & $s d^{(b)}$ & Maximum Result ${ }^{(b)}$ & Comments \\
\hline Bis(2-hexylethyl) phthalate & 1 & - & - & 1.0 & $\begin{array}{l}\text { Estimated value; common lab } \\
\text { contaminant }\end{array}$ \\
\hline Butylbenzyl phthalate & 1 & - & -- & 1.0 & Estimated value \\
\hline \multirow[t]{2}{*}{ Aluminum } & $F=4$ & 39.4 & 35.1 & 88 & \\
\hline & $\mathrm{U}=11$ & 539.9 & $1,037.3$ & 3,500 & \\
\hline \multirow[t]{2}{*}{ Barium } & $F=16$ & 57.1 & 4.1 & 70 & \\
\hline & $\mathrm{U}=25$ & 59.4 & 7.1 & 85 & \\
\hline \multirow[t]{2}{*}{ Calcium } & $F=15$ & 23,880 & 1,025 & 27,400 & \\
\hline & $U=24$ & 24,663 & 1,455 & 29,600 & \\
\hline \multirow[t]{2}{*}{ Chromium } & $F=8$ & 6.2 & 2.1 & 10 & \\
\hline & $U=26$ & 27.0 & 33.5 & 150 & \\
\hline \multirow[t]{2}{*}{ Iron } & $\mathrm{F}=11$ & 36 & 16 & 72 & \\
\hline & $\mathrm{U}=20$ & 691 & 1,315 & 5,800 & \\
\hline \multirow[t]{2}{*}{ Magnesium } & $F=15$ & 10,167 & 408 & 11,100 & \\
\hline & $U=24$ & 10,517 & 521 & 12,000 & \\
\hline \multirow[t]{2}{*}{ Manganese } & $F=15$ & 47.8 & 42.6 & 120 & \multirow{2}{*}{$\begin{array}{l}\text { Unfiltered max. is suspect } \\
\text { result }\end{array}$} \\
\hline & $\mathrm{U}=\mathbf{2 3}$ & 45.3 & 51.6 & 170 & \\
\hline \multirow[t]{2}{*}{ Nickel } & $F=2$ & 19.5 & 2.1 & 21 & \\
\hline & $\mathrm{U}=12$ & 30.1 & 21.2 & 80 & \\
\hline \multirow[t]{2}{*}{ Potassium } & $F=15$ & 4,882 & 420 & 5,630 & \multirow{2}{*}{$\begin{array}{l}\text { Filtered max. is estimated value } \\
\text { Unfiltered max. error }= \\
5,740 \text { ug/L }\end{array}$} \\
\hline & $\mathrm{U}=24$ & 4,921 & 482 & 6,000 & \\
\hline \multirow[t]{2}{*}{ Silicon } & $F=8$ & 19,713 & 683 & 22,100 & \\
\hline & $U=16$ & 20,731 & 1,452 & 23,800 & \\
\hline \multirow[t]{2}{*}{ Sodium } & $F=15$ & 35,753 & 1,693 & 40,000 & \\
\hline & $U=24$ & 36,013 & 990 & 38,600 & \\
\hline \multirow[t]{2}{*}{ Uranium } & $\mathrm{F}=2$ & 6.65 & 0.07 & 6.7 & \\
\hline & $U=16$ & 6.41 & 0.59 & 7.6 & \\
\hline \multirow[t]{2}{*}{ Vanadium } & $F=14$ & 22.5 & 5.0 & 31 & \multirow[t]{2}{*}{-} \\
\hline & $U=23$ & 24.8 & 3.4 & 31 & \\
\hline \multirow[t]{2}{*}{$\overline{\text { Zinc }}$} & $F=5$ & 26.4 & 21.7 & 63 & \\
\hline & $U=15$ & 44.6 & 39.8 & 140 & \\
\hline Ammonia & 5 & 52 & 22 & 80 & \\
\hline Alkalinity & 25 & 136,520 & 4,145 & 144,000 & \\
\hline $\begin{array}{l}\text { Specific conductance } \\
\text { (conductivity) }\end{array}$ & 94 & 355.6 & 16.5 & 393 & Units in $\mu \mathrm{mhos} / \mathrm{cm}$ \\
\hline Turbidity & 32 & 11.6 & 25.2 & 110 & $\begin{array}{l}\text { In nephelimetric turbidity units } \\
\text { (NTU) }\end{array}$ \\
\hline$\overline{\mathrm{pH}}$ & 87 & 8.1 & 0.3 & $\begin{aligned} \text { Maximum } & =8.31 \\
\text { Minimum } & =7.64\end{aligned}$ & In $\mathrm{pH}$ units \\
\hline Total dissolved solids & 19 & 228,684 & 18,577 & 270,000 & \\
\hline
\end{tabular}


Table 4.3. (contd)

\begin{tabular}{|c|c|c|c|c|c|}
\hline Constituent & $n^{(a)}$ & mean $^{(b)}$ & $\operatorname{sd}^{(b)}$ & Maximum Result ${ }^{(b)}$ & Comments \\
\hline Total organic carbon & 14 & 368 & 347 & 1,430 & \\
\hline Nitrate (includes $\mathrm{N}$ in $\mathrm{NO}_{3}$ ) & 22 & 2,760 & 3,508 & 17,000 & $\begin{array}{l}\text { Max. is suspect result; mean } \\
\text { without max. included = } \\
2,376 \text { ug/L }\end{array}$ \\
\hline $\mathrm{Nin} \mathrm{NO}_{2}$ & 10 & 14 & 9 & 20 & \\
\hline Chloride & 22 & 7,932 & 210 & 8,500 & \\
\hline Sulfate & 22 & 23,974 & 2,356 & 32,000 & \\
\hline Fluoride & 22 & 734 & 196 & 1,100 & \\
\hline Total suspended solids & 4 & 2,750 & 2,582 & 5,000 & \\
\hline Radium-226 & 5 & 0.27 & 0.40 & 0.99 & $\mathrm{pCi} / \mathrm{L}$ \\
\hline Gross alpha & 22 & 5.28 & 1.39 & 8.26 & $\mathrm{pCi} / \mathrm{L}$ \\
\hline Gross beta & 22 & 5.73 & 2.19 & 10.3 & $\mathrm{pCi} / \mathrm{L}$ \\
\hline Oil and gas & 6 & 11,137 & 17,980 & 47,700 & See text for discussion \\
\hline
\end{tabular}

the unconfined aquifer system; and are discussed in more detail in Section 4.3. The end-of-pipe discharge sample produced a result of $65 \pm 11 \mathrm{pCi} / \mathrm{L}$ tritium, which is within the expected range of activities for Columbia River water downstream of the Hanford Site (Dirkes and Hanf 1997).

\subsection{Major Ion Chemistry}

Averaged results for major ionic species in groundwater $\left(\mathrm{Na}+\mathrm{K}, \mathrm{Ca}, \mathrm{Mg}, \mathrm{Cl}, \mathrm{HCO}_{3}\right.$, and $\left.\mathrm{SO}_{4}\right)$ were calculated and plotted in milliequivalents as Stiff diagrams for 12 wells in the vicinity of TEDF and for TEDF effluent (Figure 4.2). Bicarbonate proportion was estimated based on charge balance with the other major ions. Averages were used because of a lack of time-correlatable results, either within a particular well or between wells in Figure 4.2. These averages represent samples taken over a few years and some variations in ionic concentrations over this time period are worth noting. Sulfate has increased by $\sim 3 \mathrm{x}$ in well $699-44-39 \mathrm{~B}$ during the past year, but this recent change does not significantly affect the long term average for sulfate in this well. Chloride concentrations show gradual, downward trends in wells 699-42-39B and 699-43-41G, and a 50\% decrease in concentration in well 699-42-40A since 1986. Calcium increased somewhat in well $699-42-40 \mathrm{~A}$ during the late $1980 \mathrm{~s}$, but the average Ca concentration in this well is representative of individual results during last few years.

Characteristics apparent from the diagrams in Figure 4.2 include, most notably: 1) bicarbonate dominates the anion abundance in all wells illustrated; 2) effluent from the TEDF closely resembles groundwater from wells 699-40-42A and 699-44-39B, with notably lower $\mathrm{Na}+\mathrm{K}$ and $\mathrm{HCO}_{3}^{-}$proportions 

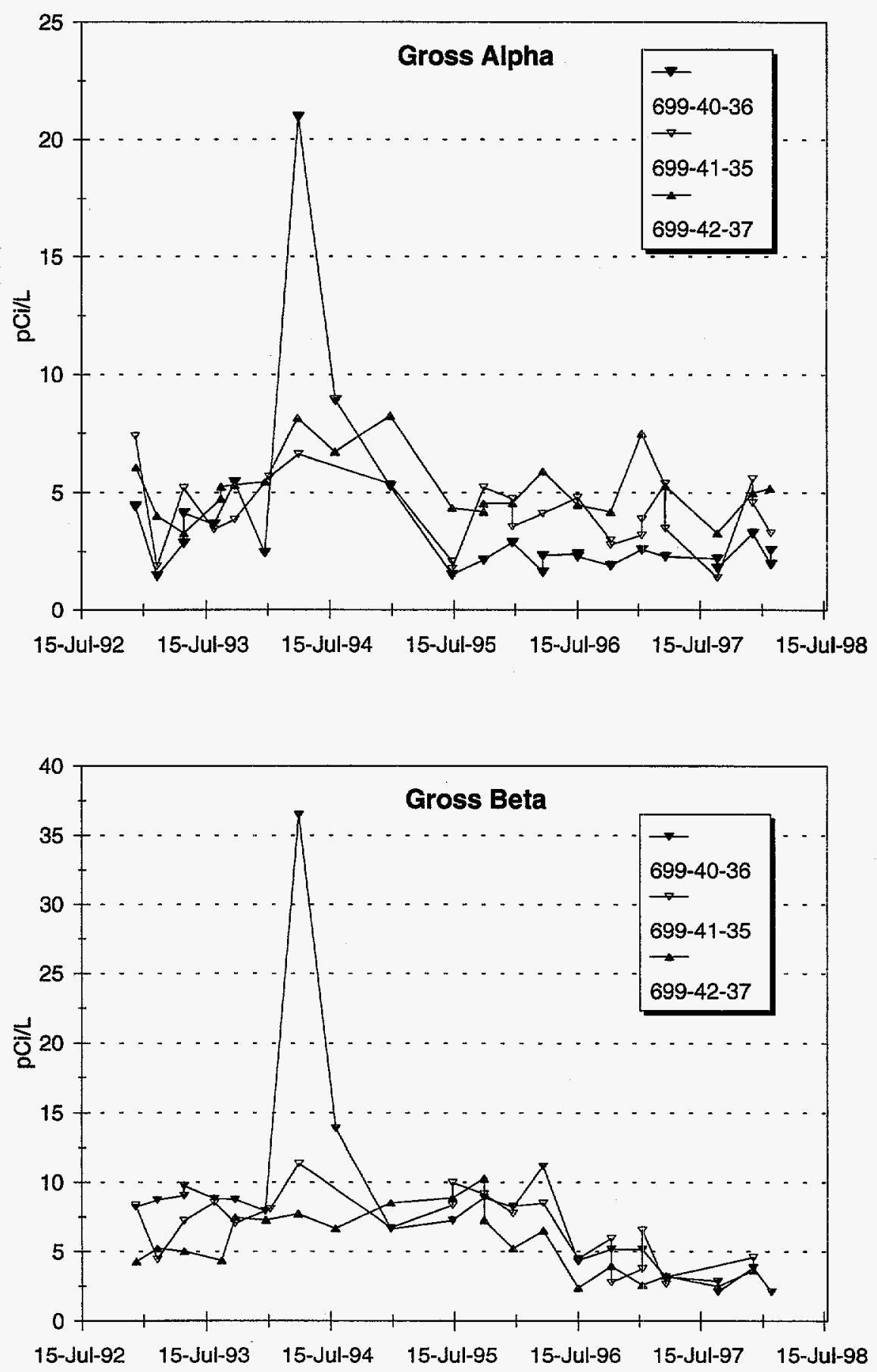

Figure 4.1. Plots of Gross Alpha and Gross Beta Results from TEDF Wells 


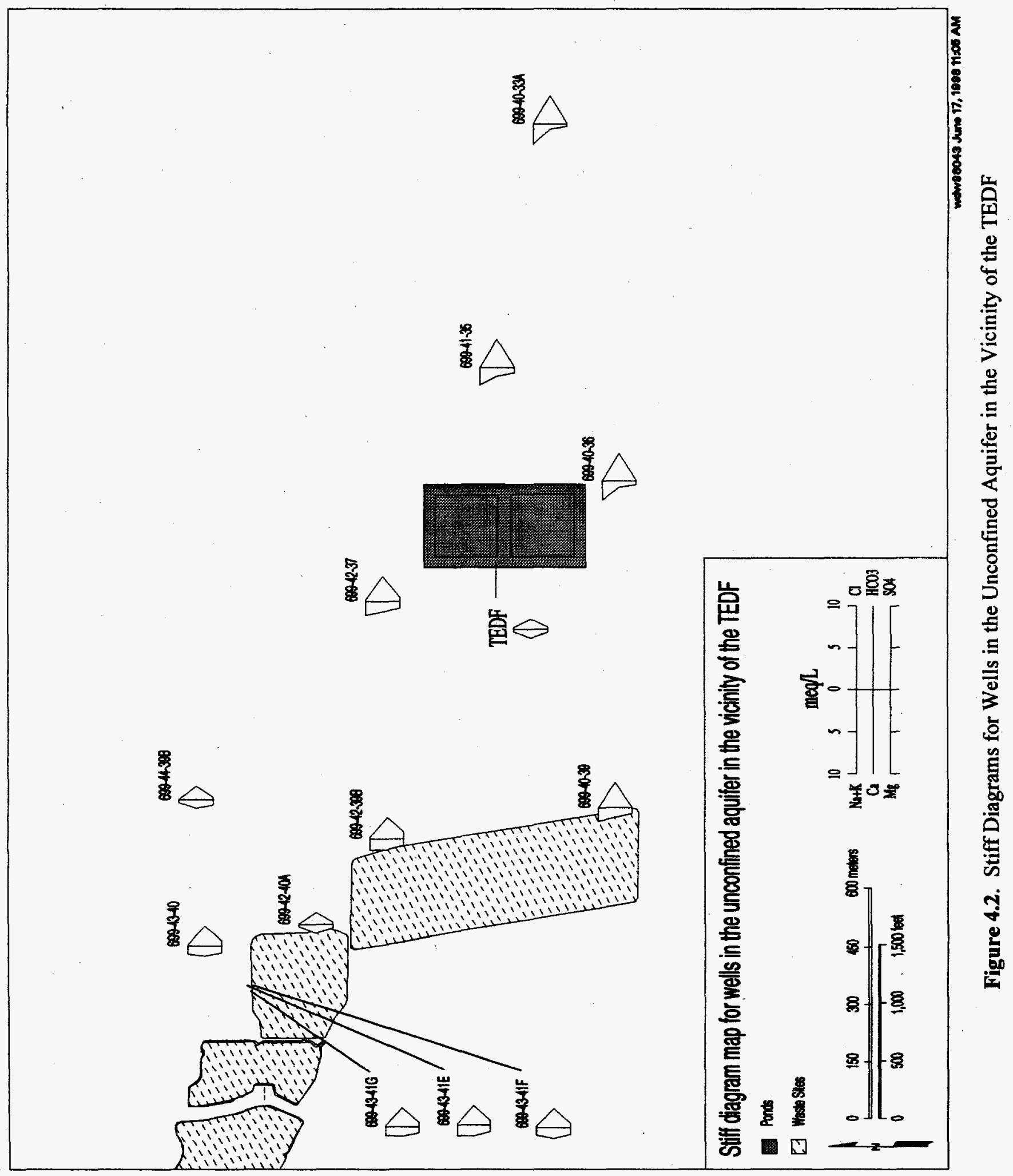


compared with other wells in the vicinity; and 3) wells in the south to southeast portion of the map have a higher proportion of $\mathrm{Na}+\mathrm{K}$ cations than those to the west and northwest.

With the exception of wells 699-42-40A and 699-44-39B, ionic concentrations for the wells in Figure 4.2 appear to be generally representative of groundwater at these locations over the averaged periods for the wells. Well $699-42-40 \mathrm{~A}$ is an older well located near the discharge site for effluent sent to the 216-B-3C expansion pond during the past 4 years (now discontinued). It is likely that this well, and possibly well 699-44-39B, have been significantly affected by dilute discharges to the pond (see discussion in 4.3). Groundwaters in wells 699-40-33A and 699-41-35 show a slight electrical imbalance (see below), but not great enough to invalidate the analyses.

As a check of the analyses, charge balance was calculated for the 12 wells shown in Figure 4.2 . Generally, anion/cation analyses are considered to be "reasonably" in balance if charge is within 5\%. Reasons for imbalances greater than this may be attributed to sampling/laboratory errors, neglect of a major dissolved ionic species, precipitation in the sample, or a combination of these factors (Deutsch 1997). In the present case, the effects of comparing analyses averaged over time may also contribute to slight imbalances. Calculations of charge balance, concentrations of major ions, and other related properties for the 12 wells of Figure 4.2 are included in Appendix C. Only two wells, 699-40-33A and $699-41-35$, barely exceeded the $5 \%$ criterion at $-5.04 \%$ and $+5.45 \%$, respectively. Because $\mathrm{NO}_{3}{ }^{-}$is often an important ionic constituent in groundwaters, this species was included in charge calculations to determine its importance. In most cases, inclusion of $\mathrm{NO}_{3}{ }^{-}$improved charge balance very slightly. In the most pronounced example in well $699-42-39 \mathrm{~B}$, addition of $\mathrm{NO}_{3}{ }^{-}$improved the charge balance from $+3.00 \%$ to $+0.45 \%$. In some cases (e.g., well 699-42-40A), inclusion of this species in charge calculations slightly increased charge imbalance. Based on this test, $\mathrm{NO}_{3}{ }^{-}$generally was not considered an important component of the major ionic constituents in the immediate area.

\subsection{Discussion of TEDF Groundwater Geochemistry}

Groundwater in wells nearest the B Pond System is predominantly of a calcium-bicarbonate type, but southward and eastward of this area, particularly east of TEDF, sodium-bicarbonate becomes more dominant (Figure 4.1). Johnson, in DOE-RL (1992), and Spane and Webber (1995) describe major ion chemistry from the upper basalt confined aquifer system. These two studies indicate that groundwater from the upper basalt confined aquifer system are predominantly sodium-bicarbonate waters, particularly in eastern portion of the Hanford Site. Johnson (DOE 1992) also notes that with increased age of the groundwater, sodium bicarbonate waters become predominant in the confined aquifer system (Figure 4.3). Stiff diagrams constructed for several wells in this aquifer system closely resemble the proportions of Stiff diagrams immediately south and east of the TEDF (Figures 4.3 and 4.4).

Except for areas near the center of the hydraulic mound generated by the B Pond System (see Figure 3.6), the vertical component of hydraulic potential in the eastern portion of Hanford Site is directed upward, from the upper basalt confined system to the unconfined aquifer (Spane and Webber 1995). 


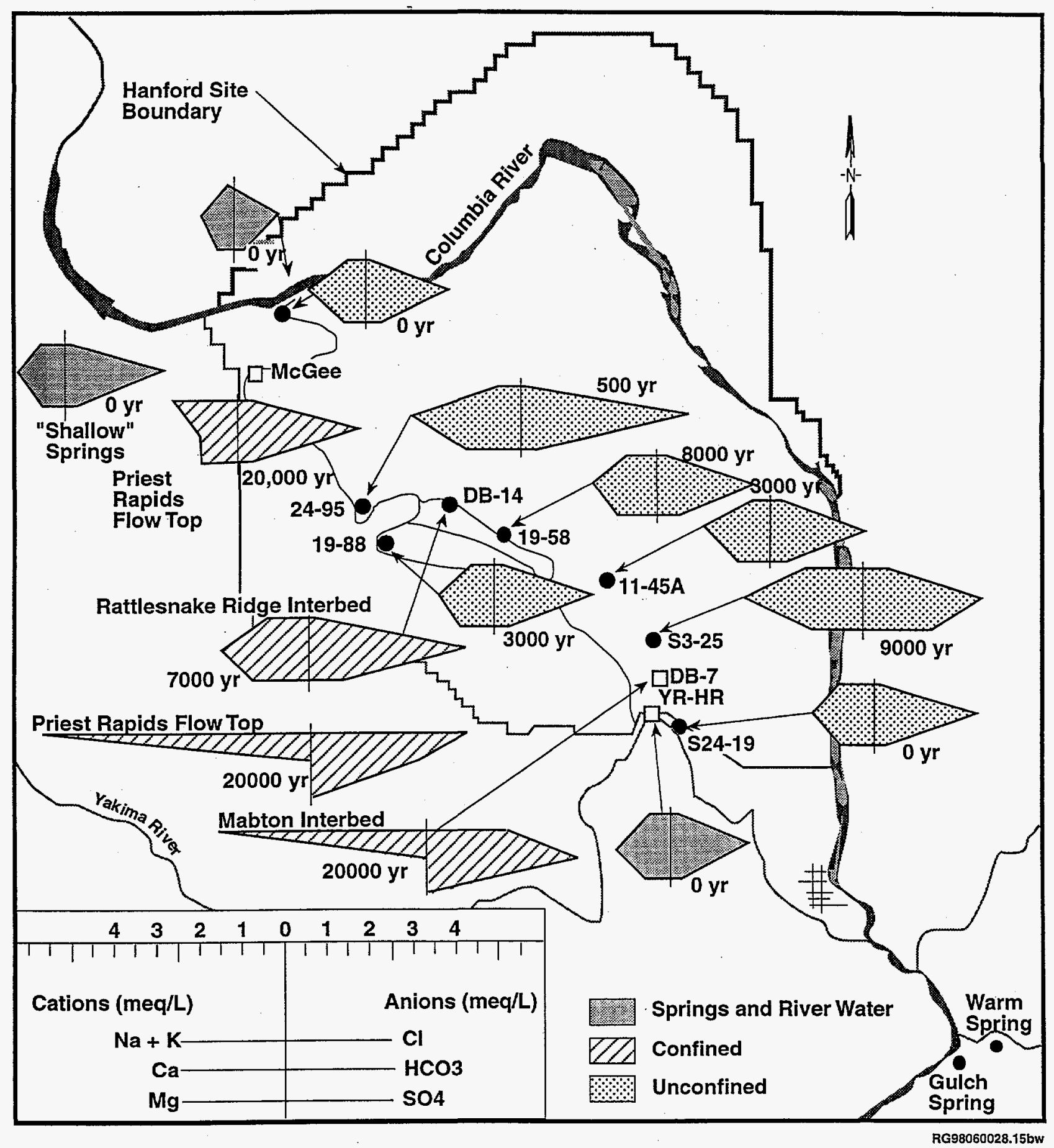

Figure 4.3. Stiff Diagrams and Age Estimates for Groundwaters and Surface Waters in the Vicinity of the Hanford Site (from V. G. Johnson in DOE-RL 1992) 


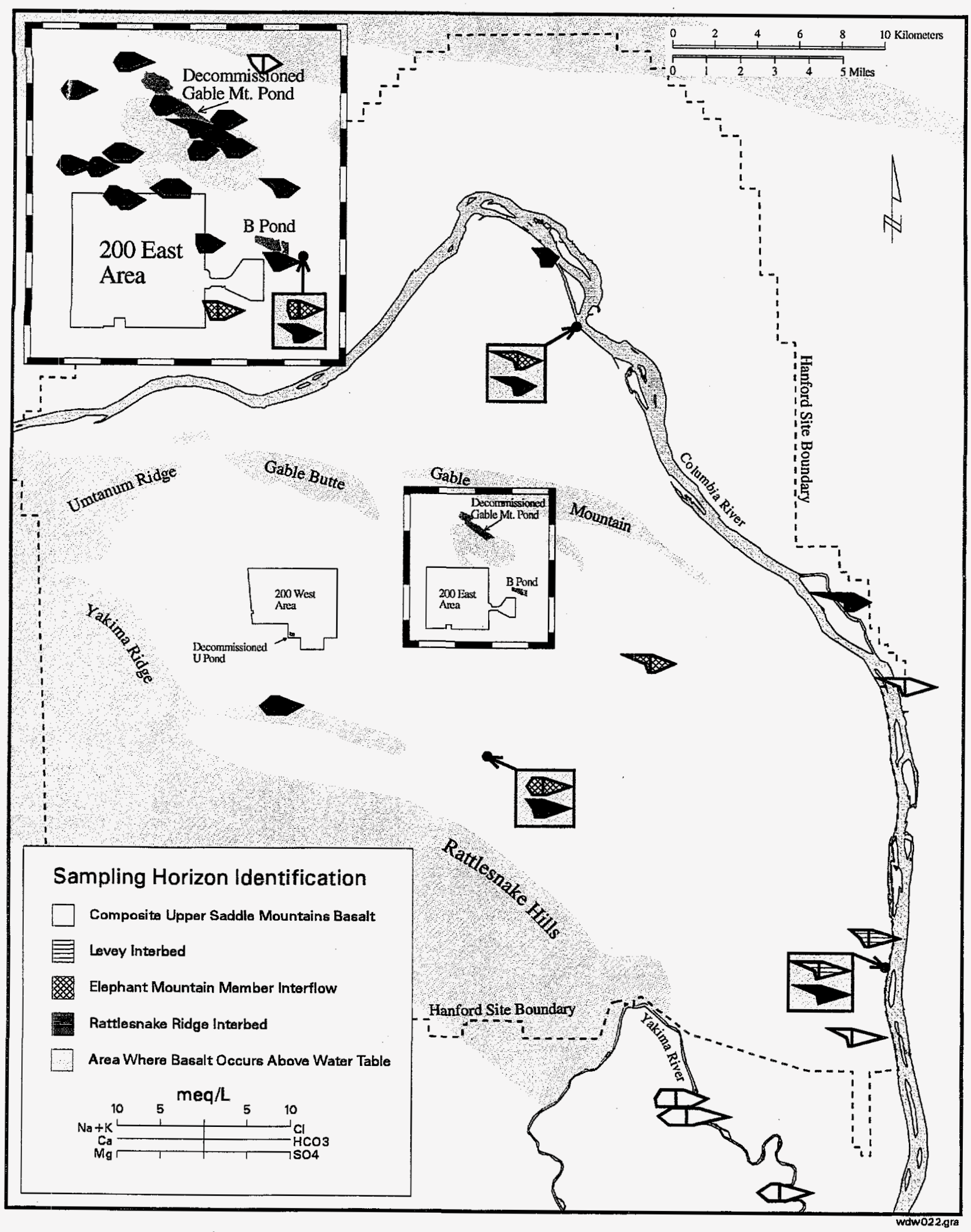

Figure 4.4. Hydrochemical Facies Stiff Diagram Map for Groundwater Within the Upper Basalt Confined Aquifer System (After Spane and Webber 1995) 
Webber $^{(a)}$ has posited that similarities in the major ion chemistry between waters from some wells in the Rattlesnake Ridge Interbed confined aquifer and those within wells near TEDF (Figure 4.2) may indicate discharge of groundwater from the upper basalt confined system to the unconfined aquifer. This could occur through structural discontinuities in the basalt, at the base of the unconfined aquifer.

Ionic strength and total dissolved solids (TDS) are lowest in both the effluent discharged to the TEDF and groundwater sampled from wells 699-42-40A and 699-44-39B. These wells are near the former discharge point of effluent sent to the B Pond System for the past few years, and near an interpreted area of discontinuities in the Ringold lower mud unit. Discharge to that facility ended in August 1997 (see Section 1.2), and the effluent was redirected to the TEDF. In fact, most effluent now sent to TEDF is of the same origin as that formerly sent to the $3 \mathrm{C}$ expansion pond of the B Pond System. Thus, it is not unexpected that the ionic character of groundwater near the former discharge point at the B Pond facility resembles that for the end-of-pipe at TEDF (Figure 4.1).

Elevated nitrate concentrations and tritium activities in groundwater within the upper basalt confined aquifer have been suggested as indicators for intercommunication with the overlying unconfined aquifer (Spane and Webber 1995). Recent analyses for tritium in the three TEDF wells indicate tritium activities $<4.41 \mathrm{pCi} / \mathrm{L}$ (below detection). In contrast, farther west and northwest near the B Pond System, tritium activities exceed $50,000 \mathrm{pCi} / \mathrm{L}$ in several wells. Likewise, nitrate is atypically low for the uppermost aquifer (lower than established background) in the area of TEDF, and has been low even before operations began at this facility. Upgradient well $699-42-37$ is nearer the B Pond System and is the exception, with a nitrate average well above the two downgradient wells (Table 4.3 and Appendix C). These circumstances would tend to lend additional credence to the proposal that upward incursion of groundwater may be occurring from the upper basalt confined aquifer system into the (regionally) unconfined aquifer.

Figure 4.1 suggests that a period of high results for gross alpha and gross beta occurred nearly simultaneously in these three wells (except for gross beta in well 699-42-37) in early 1994. This occurrence is suspicious because the three wells are separated by up to $0.6 \mathrm{~km}$ along the approximate pathway that groundwater is interpreted to be moving. That these wells would all experience an incursion of a constituent virtually simultaneously seems improbable, unless the high occurrences represent separate "pulses" that happened to coincide. Such apparent low-level pulses of these indicators are also observed in several B Pond System wells to the west of the TEDF (Barnett and Chou 1998), but the actual cause(s) and implications of these occurrences are not resolved. Additionally, changes in analytical laboratories during this time period add to the suspicion that gross beta and gross alpha results may not be representative of groundwater in these wells. These factors, and the overall low levels of activity for these indicators, warrant caution in the interpretation of Figure 4.1.

(a) W. D. Webber personal communication. 


\subsection{Conceptual Model of TEDF Effluent Fate}

Based on the foregoing discussions of effluent chemistry, groundwater hydrology, and groundwater geochemistry, a simple conceptual model of hydrochemical and hydrodynamic relationships at the TEDF is synthesized here. Figure 5.1 is a schematic representation of hydrogeologic relationships at the TEDF. The figure illustrates the infiltration of water from the two basins through the Hanford formation (mostly sand and gravel) to the Ringold lower mud unit, then quickly spreading laterally along the upper surface of the lower mud unit. The lateral spreading occurs because of the extreme contrast between the saturated hydraulic conductivity $\left(\mathrm{K}_{\mathrm{s}}\right)$ of the Hanford formation sediments and the $\mathrm{K}_{\mathrm{s}}$ of the lower mud unit (Section 3.2). Because of a structural bias in the lower mud unit (a generally southward dip), most of the effluent may flow south or southeastward along the top of this unit. No appreciable downward movement through the lower mud unit is indicated in the vicinity of the TEDF. Effluent may also move, to a much lesser degree, to the northeast or north.

Hydrogeologic Component. Drilling data from TEDF wells and nearby wells at the B Pond System indicate that the Ringold lower mud unit is up to $26 \mathrm{~m}$ thick in the vicinity of the TEDF and no discontinuities in the unit were observed in drill holes within $\sim 1 \mathrm{~km}$ of the facility. The lower mud unit is relatively impermeable; $\mathrm{K}_{\mathrm{s}}$ estimates are as low as $7.5 \mathrm{E}-09 \mathrm{~cm} \cdot \mathrm{sec}^{-1}$ in some samples (see Section 3.2). The unit is saturated for nearly its entire thickness in the vicinity of TEDF, to within $\sim 1 \mathrm{~m}$ of the its contact with the overlying Hanford formation. The extreme contrast in hydraulic conductivities between the Ringold lower mud unit and the overlying Hanford formation suggests that effluent will have a strong impetus to move preferentially laterally, rather than downward through the relatively impermeable lower mud unit. The effluent may eventually reach the southern, southeastward, or northern limit of the lower mud unit and mingle with groundwater in the uppermost aquifer.

Hydraulic head data for the unconfined aquifer and the upper basalt confined aquifer system indicate that an upward gradient could currently exist between these aquifers in the region of the TEDF. Hydrographs of the three TEDF wells reflect the decline in the hydraulic mound at the B Pond System. In fact, the most pronounced decline in water levels in TEDF wells began in 1995, the year the TEDF began operating. This decline has not perceptibly abated since then, and has even accelerated, especially in well 699-42-37 (Figure 3.5).

Geochemical Component. Groundwater chemistry in TEDF monitoring wells does not reflect the effects of the dilute discharges to the facility that have occurred over the past 3 years or to the B Pond System several years prior to TEDF operation. A comparison of major ion proportions (Figure 4.2) indicates that groundwater beneath the TEDF is significantly different from groundwater in the B Pond area to the northwest and from the effluent entering the TEDF. These effluents are largely Columbia River water mixed with steam condensate (see Section 1.3). The ionic composition of groundwater in the TEDF wells is probably a combination of effluent discharged to the B Pond System that has evolved in traveling southeastward to TEDF, and possibly the influence of upward incursion of groundwater from the upper basalt confined aquifer (dominance of $\mathrm{Na}+\mathrm{K}$ cations). Tritium analyses of groundwater beneath TEDF indicate that the aquifer in this area is anomalously low in tritium compared with surrounding areas in this same aquifer. Recent tritium results for all three TEDF wells were $<4.41 \mathrm{pCi} / \mathrm{L}$. This value is significantly less than either TEDF or B Pond System effluent or Columbia River water (Dirkes and Hanf 1997). These circumstances support a hypothesis that water from the upper basalt confined aquifer system may be moving upward into the regionally unconfined aquifer in this area. 


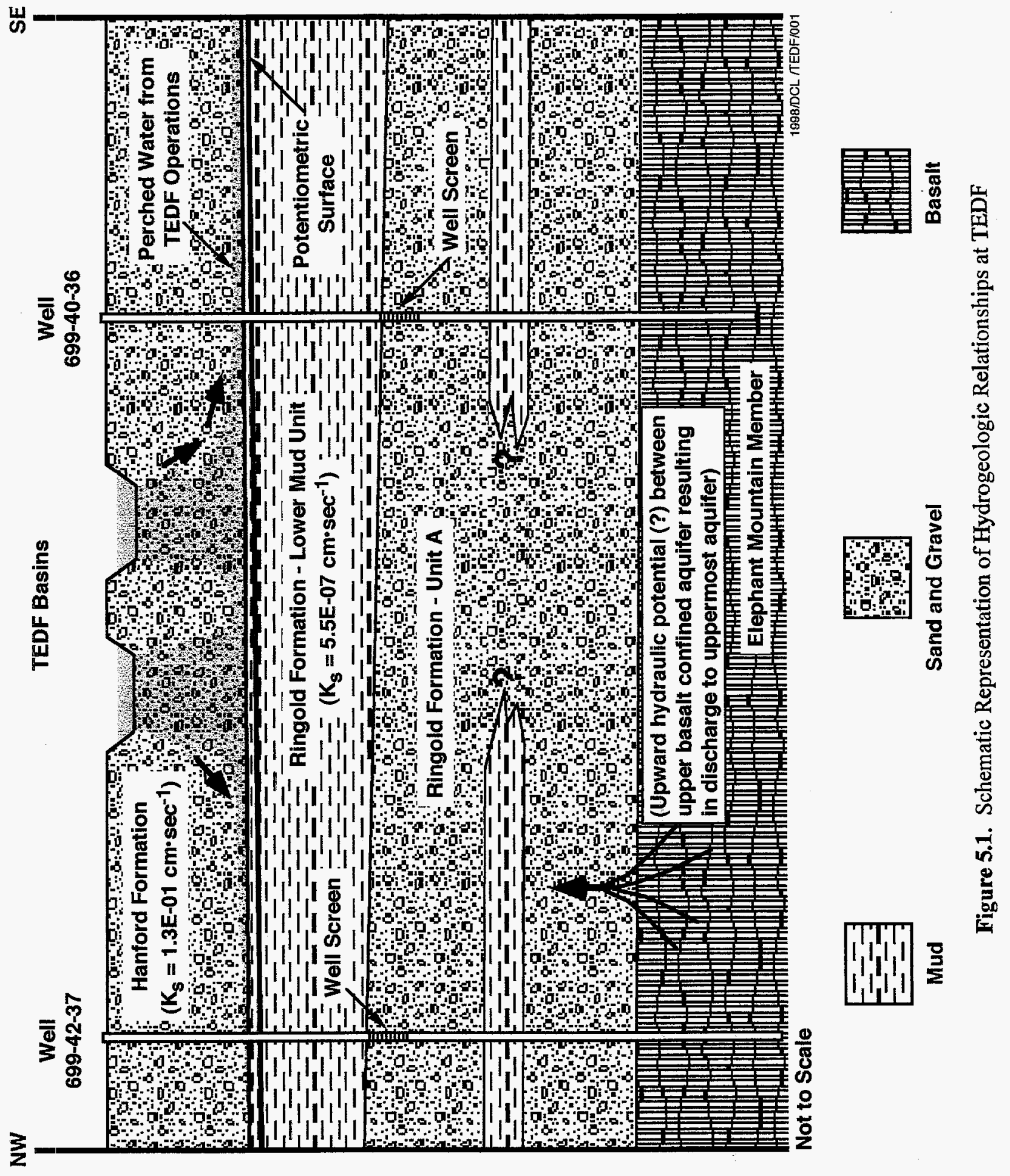




\subsection{Conclusions and Recommendations}

This section summarizes the effective elements of the current monitoring plan, examines the viability of known alternatives, and recommends actions for continued groundwater monitoring at the TEDF. Hydrogeologic evidence and ongoing hydrologic and geochemical data evaluation indicate that the uppermost aquifer beneath the TEDF is thus far unaffected by effluent disposal to the facility. The lateral consistency and impermeable nature of the Ringold lower mud unit have apparently provided an exceptionally effective protective feature that isolates TEDF operations from the uppermost aquifer in the vicinity of the facility. The TEDF monitoring wells have been effective in demonstrating this separation. Additional historical data from surrounding wells have helped confirm these conclusions.

Hydrographs of TEDF wells show that TEDF operations have had no detectable effects on hydraulic heads in the uppermost aquifer, but show a continuing decay of the hydraulic mound generated by past operations at the B Pond System. Comparison of heads in the uppermost aquifer immediately northwest of the TEDF with the head in a well in the same area which is screened in the Rattlesnake Ridge Interbed (upper basalt confined aquifer), indicate that these heads are converging as the hydraulic mound at the B Pond System subsides. Further southeast, near TEDF, an upward hydraulic gradient may already exist, making potential of incursion of groundwater from the upper basalt confined aquifer to the unconfined aquifer (uppermost aquifer beneath TEDF) more likely. This condition would hamper downward movement of effluent of TEDF into the uppermost aquifer, particularly if no substantial groundwater mound is created beneath the TEDF. The creation of a substantial mound is unlikely due to the extreme contrasts in hydraulic conductivities between the Hanford formation and the Ringold lower mud unit.

Comparison of groundwater geochemistry from TEDF wells and other, nearby RCRA wells suggests that groundwater beneath TEDF is unique; different from both effluent entering TEDF and from groundwater in the B Pond area. Tritium concentrations, major ionic proportions, and lower-than-background concentrations of other species suggest that groundwater in the uppermost aquifer beneath the TEDF bears characteristics of water in the upper basalt confined aquifer system.

Alternative approaches to monitoring have been proposed in the past, including additional monitoring points in the uppermost aquifer (e.g., coordination with other monitoring programs), deferral to end-ofpipe monitoring (discontinuance of groundwater monitoring), and vadose zone monitoring.

Additional monitoring points could be added through coordination with other existing Hanford Site groundwater monitoring efforts, mostly RCRA and sitewide monitoring. These existing wells would monitor groundwater for highly mobile contaminants in areas beyond the immediate vicinity of the TEDF. However, preexisting groundwater contamination in areas downgradient of TEDF, which originate from operations at the B Pond System and the 200 East Area, would tend to obscure any remnant signature of disposal to the TEDF (see Hartman and Dresel 1998). Therefore, addition of distal wells to monitor groundwater solely to distinguish TEDF operational effects would not be effective.

Vadose zone monitoring would require drilling of new wells in the vicinity of the TEDF to intercept effluent that has infiltrated through the vadose zone and impounded on the Ringold lower mud unit. The 
impracticality of this strategy is obvious from the earlier discussions of the hydrogeology at this site. The irregularity of the surface of the lower mud unit and the high contrasts in hydraulic conductivity between this unit and the overlying Hanford formation (vadose zone) make it highly problematic whether artificially emplaced groundwater could be intercepted in a well. Further, there is little utility in monitoring effluent in a well immediately beneath the point of infiltration.

Recommendations. Based on the hydrogeologic and hydrogeochemical conceptual model for the TEDF, the current groundwater monitoring well network appears to be effective in protecting the uppermost aquifer beneath the facility. Additionally, travel times of effluent from TEDF operations to the uppermost aquifer are probably $>3$ years, since no demonstrable effects of dilute effluent have been seen in monitoring wells. Extensive analyses of organic and chlorinated organic compounds have rendered few results, most of which are attributed to laboratory contamination. Given these circumstances, and the conditions described in Sections 3.0 through 5.0, the following measures are recommended for TEDF groundwater monitoring.

- The TEDF groundwater monitoring well network should remain the same, with the three wells (699-40-36, 699-41-35, and 699-42-37) currently used. This network will continue to help confirm that TEDF effluent is not affecting the uppermost aquifer near the facility.

- Frequency of groundwater sampling and analysis in TEDF wells should be reduced to annual or semiannual.

- Volatile and semi-volatile organic compounds analyses and WTPH-G analysis should be replaced with total organic carbon (TOC; already on the list) and total organic halogens (TOX). Cyanide and ammonium analyses should also be considered for discontinuation. These parameters have produced no results of sufficient magnitude to allow evaluation.

- TOX and TOC could be evaluated by statistical methods to screen for organic and chlorinated organic compounds.

- Radium (226 and 228) analyses should be discontinued. All results for these species have been extremely low. Gross beta analyses will screen efficiently for these radionuclides.

- End-of-pipe discharges should be reevaluated statistically to update the effluent variability evaluation of 1995 (Chou and Johnson 1996).

- Currently, all groundwater data for the TEDF are reported quarterly in Discharge Monitoring Reports. To evaluate the effectiveness of groundwater monitoring and implications of the reported data, a briefing or summary report should be assembled annually. 


\subsection{References}

40 CFR 264, Code of Federal Regulations, Title 40, Part 264, "Standards for Owners and Operators of Hazardous Waste Treatment, Storage, and Disposal Facilities."

40 CFR 265, Code of Federal Regulations, Title 40, Part 265, "Interim Status Standards for Owners of Hazardous Waste Treatment, Storage, and Disposal Facilities."

Barnett, D. B., J. D. Davis, L. B. Collard, P. B. Freeman, and C. J. Chou. 1995. Groundwater Screening Evaluation/Monitoring Plan-200 Area Treated Effluent Disposal Facility (Project W-049H).

WHC-SD-EN-WP-012, Rev. 1, Westinghouse Hanford Company, Richland, Washington.

Barnett, D. B., and C. J. Chou. 1998. Groundwater Monitoring Plan for the Hanford Site 216-B-3 Pond Facility. PNNL-1 1903, Pacific Northwest National Laboratory, Richland, Washington.

Barnett, D. B., and S. S. Teel. 1997. Results of RCRA Groundwater Quality Assessment at the 216-B-3

Pond Facility. PNNL-11604, Pacific Northwest National Laboratory, Richland, Washington.

Chou, C. J., and V. G. Johnson. 1996. Effluent Variability Study Results for the 200 Area Treated Effluent Disposal Facility. WHC-SD-LEF-EV-001, Rev. 0, Westinghouse Hanford Company, Richland, Washington.

Connelly, M. P., J. V. Borghese, C. D. Delaney, B. H. Ford, J. W. Lindberg, and S. J. Trent. 1992. Hydrogeologic Model for the 200 East Groundwater Aggregate Area. WHC-SD-EN-TI-019, Westinghouse Hanford Company, Richland, Washington.

Crane, A. F. 1998. 200 Area Treated Effluent Disposal Facility Interface Control Document.

HNF-SD-W049H-ICD-001, Rev. 5, Waste Management Hanford Company, Richland, Washington.

Davis, J. D., and C. D. Delaney. 1992. Site Characterization Work Plan-200 Areas Treated Effluent Disposal Basin, Project W-049H. WHC-SD-W049H-WP-001, Rev. 1, Westinghouse Hanford Company, Richland, Washington.

Davis, J. D., D. B. Barnett, L. C. Swanson, W. J. McMahon, and C. D. Palomares. 1993. Site Characterization Report: Results of Detailed Evaluation of the Suitability of the Site Proposed for Disposal of 200 Areas Treated Effluent. WHC-SD-EN-ES-004, Westinghouse Hanford Company, Richland, Washington.

Deutsch, W. J. 1997. Groundwater Geochemistry: Fundamentals and Applications to Contamination, CRC Press LLC, Boca Raton, Florida. 
Dirkes, R. L., and R. W. Hanf. 1997. Hanford Site Environmental Report for Calendar Year 1996. PNNL-11472, Pacific Northwest National Laboratory, Richland, Washington.

DOE-RL. 1992. Hanford Site Groundwater Background. DOE/RL-92-23, U.S. Department of Energy, Richland Operations Office, Richland, Washington.

DOE-RL. 1994. Annual Report for RCRA Groundwater Monitoring Projects at Hanford Site Facilities for 1993. DOE/RL-93-88, Rev. 0, U.S. Department of Energy, Richland Operations Office, Richland, Washington.

Ecology. 1995. State Waste Discharge Permit No. ST 4502. Washington State Department of Ecology, Olympia, Washington.

Ecology. 1997. Water Quality Standards for Ground Waters of the State of Washington. Chapter 173-200 Washington Administrative Code, Washington State Department of Ecology, Olympia, Washington.

Freshley, M. D., and M. J. Graham. 1988. Estimation of Ground-Water Travel Time at the Hanford Site: Description, Past Work, and Future Needs. PNL-6328, Pacific Northwest Laboratory, Richland, Washington.

Freshley, M.D., and P. D. Thorne. 1992. Ground-Water Contribution of Dose from Past Hanford Operations. PNWD-1974 HEDR, Pacific Northwest Laboratory, Richland, Washington.

Hartman, M. J., and P. E. Dresel (eds.). 1998. Hanford Site Groundwater Monitoring for Fiscal Year 1997. PNNL-11793, Pacific Northwest National Laboratory, Richland, Washington.

Johnson, V. G. 1993. Westinghouse Hanford Company Operational Groundwater Status Report, 19901992. WHC-EP-0595, Westinghouse Hanford Company, Richland, Washington.

Kincaid, C. T., M. P. Bergeron, C. R. Cole, M. D. Freshley, N. L. Hassig, V. G. Johnson, D. I. Kaplan, R. J. Serne, G. P. Streile, D. L. Strenge, P. D. Thorne, L. W. Vail, G. A. Whyatt, and S. K. Wurstner. 1998. Composite Analysis for Low-Level Waste Disposal in the 200 Area Plateau of the Hanford Site. PNNL-1 1800, Pacific Northwest National Laboratory, Richland, Washington.

Lindsey, K. A., B. N. Bjornstad, J. W. Lindberg, and K. M. Hoffman. 1992. Geologic Setting of the 200 East Area: An Update. WHC-SE-EN-TI-012, Westinghouse Hanford Company, Richland, Washington.

Olson, P. M. 1997. Liquid Waste Processing Facilities Quality Assurance Project Plan. WHC-SD-LEF-QAPP-002, Rev. 1, Waste Management Federal Services Hanford, Richland, Washington.

Spane, F. A., Jr., and W. D. Webber. 1995. Hydrochemistry and Hydrogeologic Conditions Within the Hanford Site Upper Basalt Confined Aquifer System. PNL-10817, Pacific Northwest National Laboratory, Richland, Washington. 
WAC 173-160. Minimum Standards for Construction and Maintenance of Wells, Part Three-Resource Protection Wells. Washington Administrative Code, Washington State Department of Ecology, Olympia, Washington.

WAC 173-216. State Waste Discharge Permit Program. Chapter 173-216 Washington Administrative Code, Washington Administrative Code, Washington State Department of Ecology, Olympia, Washington. 
Appendix A

Summary Lithologic Logs and Construction Details for TEDF Groundwater Monitoring Wells 


\section{Legend}

Lithologies
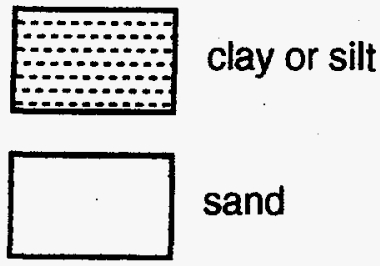

sand

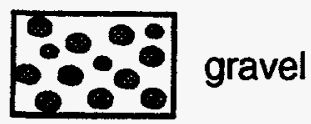

basalt

$$
--\frac{\boldsymbol{\nabla}}{(1-9-98)}-\begin{gathered}
\text { Water Table or } \\
-\begin{array}{l}
\text { potentiometric } \\
\text { surface with date } \\
\text { of measurement }
\end{array}
\end{gathered}
$$

Well Construction

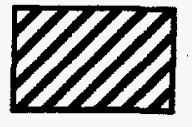

Bentonite Seal

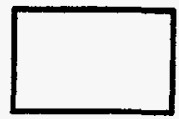

Artificial

Sand Pack

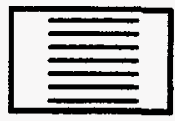

Well

Screen

Interval

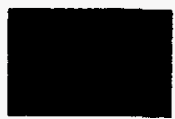

Cement

Grout

Slough

RG98060028.12 

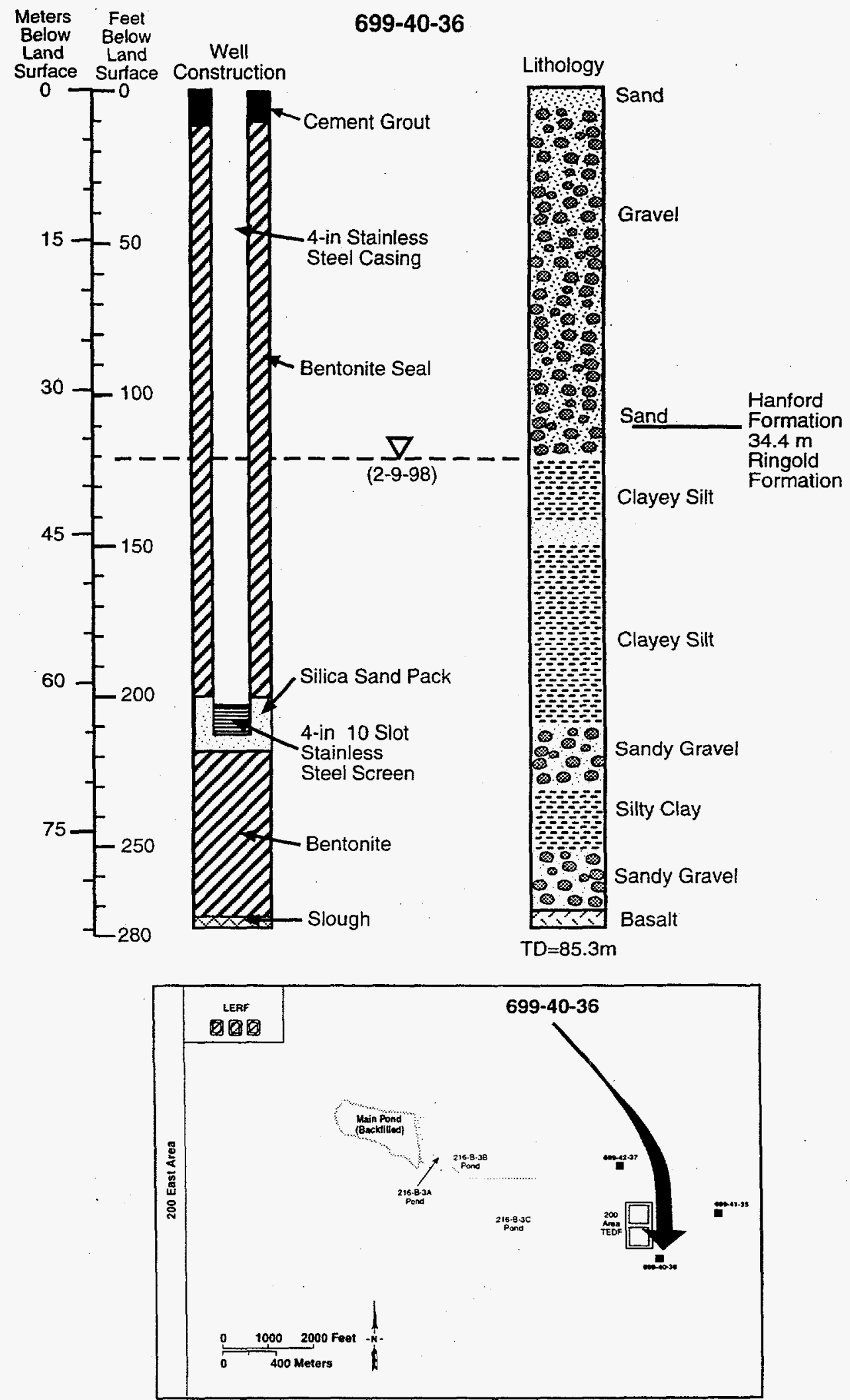

RG96080028.11

A. 2 

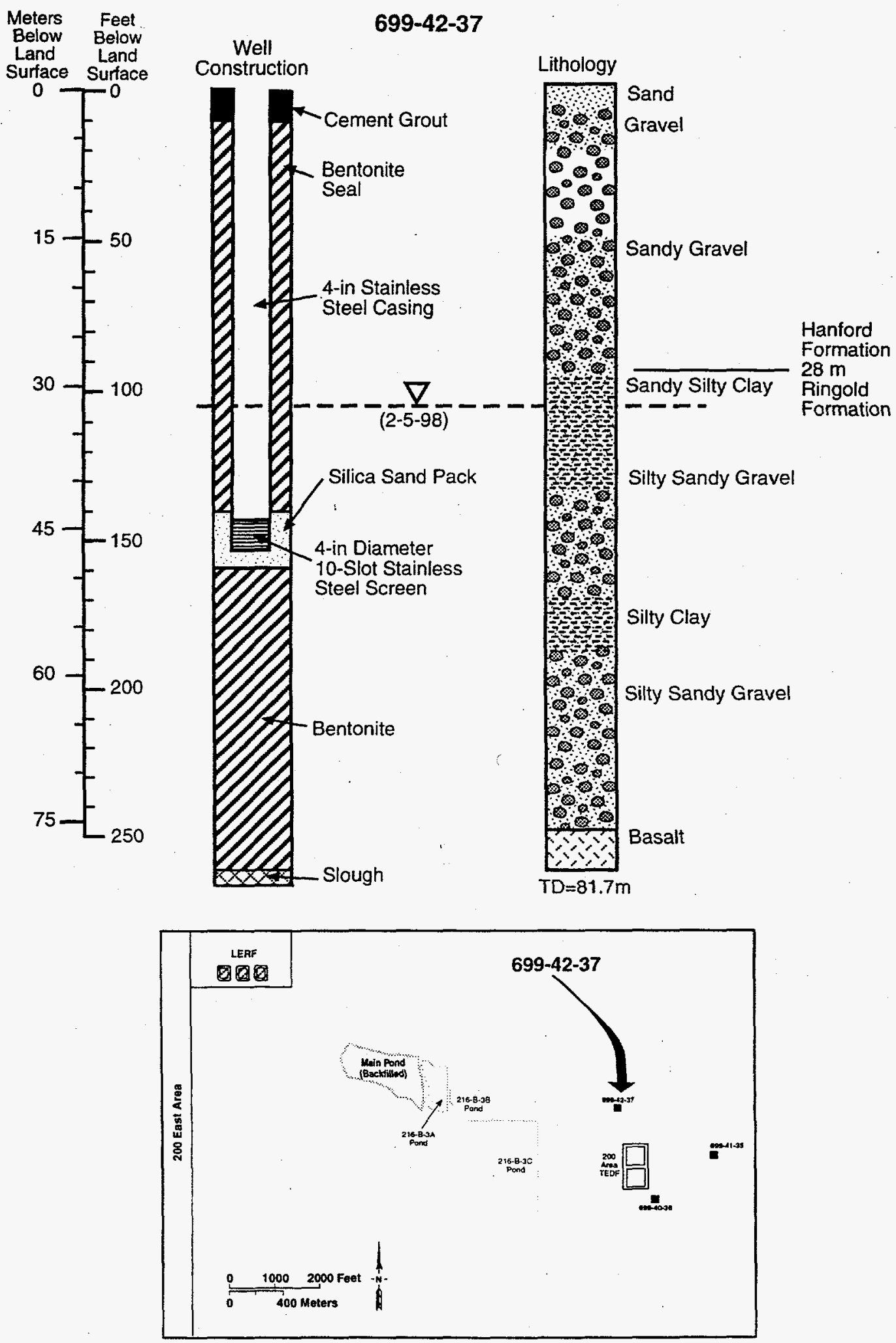

RG98060028.7 

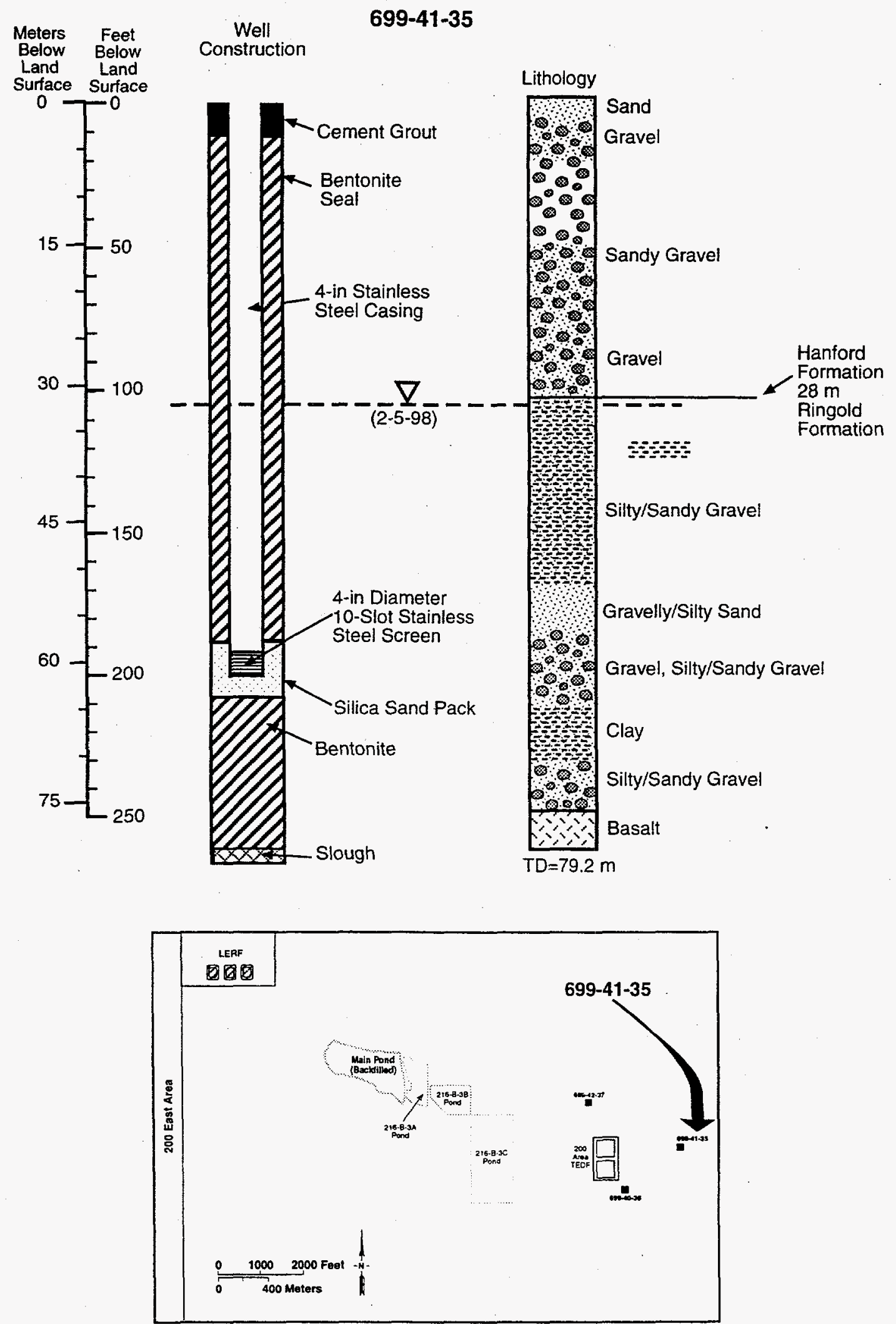

RG98060028.8 


\section{Appendix B}

Groundwater Constituents Lists for the 200 Area TEDF 


\section{Appendix B}

\section{Groundwater Constituents Lists for the 200 Area TEDF}

The following tables are the lists of constituents sought in samples from TEDF groundwater monitoring wells during the years 1992 through 1996. The current list of constituents is presented in Section 2.2 of the document.

Table B.1. Initial Groundwater Constituent List for the TEDF, 1992-1995

\begin{tabular}{|c|c|c|}
\hline \multicolumn{3}{|c|}{ Contamination indicator parameters } \\
\hline $\begin{array}{l}\mathrm{pH} \\
\text { Specific conductance }\end{array}$ & \multicolumn{2}{|c|}{$\begin{array}{l}\text { Total organic carbon } \\
\text { Total organic halogens }\end{array}$} \\
\hline \multicolumn{3}{|c|}{ Groundwater quality parameters } \\
\hline $\begin{array}{l}\text { Chloride } \\
\text { Iron }\end{array}$ & $\begin{array}{l}\text { Manganese } \\
\text { Phenols }\end{array}$ & $\begin{array}{l}\text { Sodium } \\
\text { Sulfate }\end{array}$ \\
\hline \multicolumn{3}{|c|}{ Drinking water parameters } \\
\hline $\begin{array}{l}\text { 2,4-D } \\
\text { 2,4,5-TP } \\
\text { Arsenic } \\
\text { Barium } \\
\text { Cadmium } \\
\text { Chromium } \\
\text { Coliform bacteria } \\
\text { Endrin }\end{array}$ & $\begin{array}{l}\text { Fluoride } \\
\text { Gross alpha } \\
\text { Gross beta } \\
\text { Lead } \\
\text { Lindane } \\
\text { Mercury } \\
\text { Methoxychlor }\end{array}$ & $\begin{array}{l}\text { Nitrate } \\
\text { Radium } \\
\text { Selenium } \\
\text { Silver } \\
\text { Silvex } \\
\text { Toxaphene } \\
\text { Turbidity }\end{array}$ \\
\hline \multicolumn{3}{|c|}{ Site-specific parameters } \\
\hline Ammonium & Hydrazine & Tritium \\
\hline \multicolumn{3}{|c|}{ Assessment monitoring parameters } \\
\hline $\begin{array}{l}\text { Anions* } \\
\text { Herbicides } \\
\text { Pesticides }\end{array}$ & \multicolumn{2}{|c|}{$\begin{array}{l}\text { Polychlorinated biphenyls } \\
\text { Volatile, semi-volatile organic compounds }\end{array}$} \\
\hline
\end{tabular}

B. 1 
Table B.2. Groundwater Screening List of Constituents for the TEDF, 1995-1996

\begin{tabular}{|c|c|c|c|}
\hline \multicolumn{4}{|c|}{ Part 1A. Volatile Organic Constituents } \\
\hline Constituent ID & Constituent Name & Group: & PQL(ug/L) $)^{2}$ \\
\hline $71-55-6$ & 1,1,1-Trichloroethane & SW-846 8240/8260 & 5 \\
\hline $79-00-5$ & 1,1,2-Trichloroethane & SW-846 8240/8260 & 5 \\
\hline $75-34-3$ & 1,1-Dichloroethane & SW-846 8240/8260 & 5 \\
\hline $75-35-4$ & 1,1-Dichloroethylene & SW.846 8240/8260 & 5 \\
\hline $106-93-4$ & 1,2-Dibromoethane & SW-846 8240/8260 & 5 \\
\hline $107-06-2$ & 1.2-Dichloroethane & SW-846 8240/8260 & 5 \\
\hline $78-87-5$ & 1,2-Dichloropropane & SW-846 8240/8260 & 5 \\
\hline $591-78-6$ & 2-Hexanone & SW- $8468240 / 8260$ & 5 \\
\hline $108-10-1$ & 4-Methyl-2-pentanone & SW-846 8240/8260 & 5 \\
\hline $67-64-1$ & Acetone & SW- $8468240 / 8260$ & 5 \\
\hline $107-13-1$ & Acrylonitrile & SW- $8468240 / 8260$ & 5 \\
\hline $71-43-2$ & Benzene & SW-846 8240/8260 & 5 \\
\hline $75-27-4$ & Bromodichloromethane & SW-846 8240/8260 & 5 \\
\hline $75-25-2$ & Bromoform & SW-846 8240/8260 & 5 \\
\hline $56-23-5$ & Carbon tetrachloride & SW- $8468240 / 8260$ & 5 \\
\hline $108-90-7$ & Chlorobenzene & SW-846 8240/8260 & 5 \\
\hline $67-66-3$ & Chloroform & SW-846 8240/8260 & 5 \\
\hline $124-48-1$ & Dibromochloromethane & SW-846 8240/8260 & 5 \\
\hline $100-41-4$ & Ethylbenzene & SW-846 8240/8260 & 5 \\
\hline 78-83-1 & Isobutyl alcohol & SW-846 8240/8260 & 5 \\
\hline $74-87-3$ & Methyl chloride & SW-846 8240/8260 & 5 \\
\hline $78-93-3$ & Methyl ethyl ketone & SW-846 8240/8260 & 5 \\
\hline $80-62-6$ & Methyl methacrylate & SW-846 8240/8260 & 5 \\
\hline $75-09-2$ & Methylene chloride & SW-846 8240/8260 & 5 \\
\hline $110-86-1$ & Pyridine & SW-846 8240/8260 & 5 \\
\hline $100-42-5$ & Styrene & SW-846 8240/8260 & 5 \\
\hline $127-18-4$ & Tetrachloroethylene & SW-846 8240/8260 & 5 \\
\hline $108-88-3$ & Toluene & SW-846 8240/8260 & 5 \\
\hline $79-01-6$ & Trichloroethene & SW-846 8240/8260 & 5 \\
\hline $75-01-4$ & Vinyl chloride & SW-846 8240/8260 & 5 \\
\hline $1330-20-7$ & Xylenes (total) & SW-846 8240/8260 & 5 \\
\hline $10061-01-5$ & cis-1,3-Dichloropropene & SW-846 8240/8260 & 5 \\
\hline $109-99-9$ & Tetrahydrofuran & SW-846 8240/8260 & 100 \\
\hline $156-60-5$ & trans-1,2-Dichloroethylene & SW-846 8240/8260 & 5 \\
\hline $10061-02-6$ & trans-1,3-Dichloropropene & SW'-846 8240/8260 & 5 \\
\hline & Part 1B. Non-Halogenate & anic Constituents & \& \\
\hline Constituent ID & Constituent Name & Group ${ }^{3}$ & PQL(ug/L) \\
\hline 123-91-1 & 1,4-Dioxane & Super SW-846 8015 & 150 \\
\hline $71-36-3$ & 1-Butanol & Super SW-846 8015 & 50,000 \\
\hline $141-78-6$ & Ethyl acetate & Super SW-846 8015 & 50,000 \\
\hline
\end{tabular}




\begin{tabular}{||l|l|l|r|}
\hline $60-29-7$ & Diethyl ether & Super SW-846 8015 & 50,000 \\
\hline $78-83-1$ & Isobutyl alcohol & Super SW-846-8015 & 50,000 \\
\hline $78-93-3$ & Methyl ethyl ketone & Super SW-846 8015 & 100,000 \\
\hline $64-17-5$ & Ethyl alcohol & Super SW-846 8015 & $5,000,000$ \\
\hline $107-21-1$ & Ethylene Glycol & Super SW-846 8015 & 100,000 \\
\hline- & WTPH-G & SW-846 8015 (modified) & 1,000 \\
\hline
\end{tabular}

\begin{tabular}{|c|c|c|c|}
\hline Constituent ID & Constituent Name & Group': & PQL(ug/L) \\
\hline $130-15-4$ & 1,4-Naphtoquinone & SW-946 8270 Appx IX & 10 \\
\hline $134-32-7$ & 1-Naphthylamine & SW-946 8270 Appx IX & 10 \\
\hline $88-06-2$ & 2,4,6-Trichlorophenol & SW-946 8270 Appx IX & 10 \\
\hline $121-14-2$ & 2,4-Dinitrotoluene & SW-946 8270 Appx IX & 10 \\
\hline $606-20-2$ & 2,6-Dinitrotoluene & SW-946 8270 Appx IX & 10 \\
\hline $95-57-8$ & 2-Chlorophenol & SW-946 8270 Appx IX & 10 \\
\hline $91-59-8$ & 2-Naphthylamine & SW-946 8270 Appx IX & 10 \\
\hline $91-94-1$ & 3,3'-Dichlorobenzidine & SW-946 8270 Appx IX & 20 \\
\hline $119-93-7$ & 3,3'-Dimethylbenzidine & SW-946 8270 Appx DX & 10 \\
\hline $106-44-5$ & 4-Methylphenol & SW-946 8270 Appx IX & 10 \\
\hline $98-86-2$ & Acetophenone & SW-946 8270 Appx IX & 10 \\
\hline $62-53-3$ & Aniline & SW-946 8270 Appx IX & 10 \\
\hline $140-57-8$ & Aramite & SW-946 8270 Appx IX & 20 \\
\hline $50-32-8$ & Benzo(a)pyrene & SW-946 8270 Appx DX & 10 \\
\hline $100-51-6$ & Benzyl alcohol & SW-946 8270 Appx IX & 20 \\
\hline $111-44-4$ & Bis(2-chloroethyl) ether & SW-946 8270 Appx IX & 10 \\
\hline $117-81-7$ & Bis(2-ethylhexyl) phthalate & SW-946 8270 Appx IX & 10 \\
\hline $85-68-7$ & Butylbenzylphthalate & SW-946 8270 Appx IX & 10 \\
\hline $510-15-6$ & Chlorobenzilate & SW-946 8270 Appx IX & 10 \\
\hline 218-01-9 & Chrysene & SW-946 8270 Appx IX & 10 \\
\hline $84-74-2$ & Di-n-butylphthalate & SW-946 8270 Appx IX & 10 \\
\hline $117-84-0$ & Di-n-octylphthalate & SW-946 8270 Appx IX & 10 \\
\hline $2303-16-4$ & Diallate & SW-946 8270 Appx IX & 10 \\
\hline $84-66-2$ & Diethyl phthalate & SW-946 8270 Appx IX & 10 \\
\hline $131-11-3$ & Dimethyl phthalate & SW-946 8270 Appx IX & 10 \\
\hline $118-74-1$ & Hexachlorobenzene & SW-946 8270 Appx IX & 10 \\
\hline $67-72-1$ & Hexachloroethane & SW-946 8270 Appx IX & 10 \\
\hline $78-59-1$ & Isophorone & SW-946-8270 Appx IX & 10 \\
\hline $72-43-5$ & Methoxychior & SW-946 8270 Appx IX & 10 \\
\hline $108-39-4$ & in-Cresol & SW-946 8270 Appx DX & 10 \\
\hline $924-16-3$ & N-Nitrosodi-n-butylamine & SW-946 8270 Appx DX & 10 \\
\hline
\end{tabular}




\begin{tabular}{|c|c|c|c|}
\hline Constivent ID & Constituent Name & Group' & PQL(ug/L) \\
\hline $5.5-18-5$ & N-Nitrosodiethylamine & SW-946 8270 Appx IX & 10 \\
\hline $62.75-9$ & N-Nitrosodimethylamine & SW-956 8270 Appx DX & 10 \\
\hline $85-30-6$ & N-Nitrosodiphenylamine & SW-946 8270 Appx IX & 10 \\
\hline $10595-95-6$ & N-Nitrosomethylethylamine & SW-946 8270 Appx IX & 20 \\
\hline $91-20-3$ & Naphthalene & SW-946 8270 Appx DX & 10 \\
\hline $98-95-3$ & Nitrobenzene & SW-946 8270 Appx DX & 10 \\
\hline $87-86-5$ & Pentachlorophenol & SW-946 8270 Appx DX & 50 \\
\hline $108-95-2$ & Phenol & SW-946 8270 Appx IX & 10 \\
\hline $106-50-3$ & o-Phenylenediamine & SW-946 8270 Appx DX & 10 \\
\hline $110-86-1$ & Pyridine & SW-946 8270 Appx IX & 10 \\
\hline $126-73-8$ & Tributyl Phosphate ${ }^{3}$ & SW-946 8270 Appx DX & NA \\
\hline $62: 9-50-5$ & Tridecane & SW-946 8270 Appx DX & 10 \\
\hline
\end{tabular}

\begin{tabular}{|c|c|c|c|}
\hline Constituent ID & Constituent Name & Group & $\mathrm{PQL}(\mathrm{ug} / \mathrm{L})$ \\
\hline $72-54-8$ & 4,4'-DDD & SW-846 8080 & 50 \\
\hline $72-55-9$ & 4,4'-DDE & SW-846 8080 & 10 \\
\hline $50-29-3$ & 4,4'-DDT & SW-846 8080 & 2 \\
\hline $319-84-6$ & Alpha-BHC & SW-846 8080 & 2 \\
\hline $12674-11-2$ & Aroclor-1016 & SW-846 8080 & 50 \\
\hline $11104-28-2$ & Aroclor-1221 & SW-846 8080 & 50 \\
\hline $11141-16-5$ & Aroclor -1232 & SW-846 8080 & 50 \\
\hline $53469-21-9$ & Aroclor-1242 & SW-846 8080 & 50 \\
\hline $12572-29-6$ & Aroclor-1248 & SW-846 8080 & 50 \\
\hline $11097-69-1$ & Aroclor- 1254 & SW-846 8080 & 50 \\
\hline $11096-82-5$ & Aroclor- 1260 & SW-846 8080 & 50 \\
\hline $57.74-9$ & Chlordane & SW-846 8080 & 50 \\
\hline $319-86-8$ & Delta-BHC & SW-846 8080 & 2 \\
\hline $959-98-8$ & Endosulfan I & SW-846 8080 & 2 \\
\hline $33213-65-9$ & Endosulfan II & SW-846 8080 & 10 \\
\hline $1031-07-8$ & Endosulfan sulfate & SW-846 8080 & 10 \\
\hline $72-20-8$ & Endrin & SW-846 8080 & 10 \\
\hline $7421-93-4$ & Endrin Aldehyde & SW-846 8080 & 2 \\
\hline $72-43-5$ & Methoxychlor & SW-846 8080 & 2 \\
\hline $8001-35-2$ & Toxaphene & SW-846.8080 & 50 \\
\hline $58-89-9$ & gamma-BHC (Lindane) & SW-846 8080 & 2 \\
\hline $93-72-1$ & $2,4,5-\mathrm{TP}$ & SW-846 8150 & 2 \\
\hline 94-75-7 & 2,4-D & $5 W-8468150$ & 12 \\
\hline
\end{tabular}




\begin{tabular}{|c|c|c|c|}
\hline Constituent. ID & Constinent Name & Group & PQL (ug/L) \\
\hline $7429-90-5$ & Aluminum & SW-846 6010 & 500 \\
\hline $7440-36-0$ & Antimony & SW-846 6010 & 300 \\
\hline $7440-39-3$ & Barium & SW-846 6010 & 20 \\
\hline $7440-41-7$ & Beryllium & SW-846 6010 & 10 \\
\hline $7440-42-8$ & Boron & $S W-8466010$ & 100 \\
\hline $7440-43-9$ & Cadmium & SW-846 7131A & 5 \\
\hline $7440-70-2$ & Calcium & SW-846 6010 & 500 \\
\hline $7440-47-3$ & Chromium & SW-846 7191/EPA 200.8 & 20 \\
\hline $7440-48-4$ & Cobalt & SW-846 6010 & 70 \\
\hline $7440-50-8$ & Copper & SW-846 6010 & 60 \\
\hline $7439-89-6$ & Iron & SW-846 6010 & 100 \\
\hline $7439-93-2$ & Lithium & SW-846 6010 & 100 \\
\hline $7439-95-4$ & Magnesium & SW-846 6010 & 1,000 \\
\hline $7439-96-5$ & Manganese & SW-846 6010 & 50 \\
\hline $7439-98-7$ & Molybdenum & SW-846 6010 & 100 \\
\hline $7440-02-0$ & Nickel & $S W-8466010$ & 75 \\
\hline $7440-09-7$ & Potassium & SW-846 6010 & 5,000 \\
\hline $7440-21-3$ & Silicon & SW-846 6010 & 450 \\
\hline $7440-22-4$ & Silver & SW-846 6010 & 70 \\
\hline $7440-23-5$ & Sodium & SW-846 6010 & 1,000 \\
\hline $7440-62-2$ & Vanadium & SW-846 6010 & 80 \\
\hline $7440-66-6$ & Zinc & SW-846 6010 & 20 \\
\hline $7440-67-7$ & Zirconium & SW-846 6010 & 100 \\
\hline $7440-31-5$ & Tin & SW-846 7870 & 8,000 \\
\hline $7439-92-1$ & Lead & SW-8467421 & 10 \\
\hline $7439-97-6$ & Mercury & SW-846 7470/7471 & 2 \\
\hline $7440-38-2$ & Arsenic & SW-8467060 & 15 \\
\hline $7782-49-2$ & Selenium & SW-846 7740 & 20 \\
\hline \multicolumn{4}{|c|}{ Part 5. Miscellaneous Indicators and Inorganic and Organic Constituents } \\
\hline Constixuem ID & Constituent Name & Group & PQL(ug/L) \\
\hline $14798-03-09$ & Ammonia & 40 CFR $136350.1 / 2 / 3$ & 50 \\
\hline $57-12-5$ & Cyanide & 40 CFR $136335.1 / 2 / 3$ & 50 \\
\hline ALKALNITY & Alkalinity & FIELD ANALYSIS & 500 \\
\hline CONDUCTANCE & Specific conductance (in $\mu \mathrm{mohs} / \mathrm{cm}$ ) & SW-846 9050/EPA 120.1 & 10 \\
\hline NTU & Turbidity in NTU & Std. Methods 214A & 1 \\
\hline $\mathrm{pH}$ & $\mathrm{pH}$ in $\mathrm{pH}$ units & SW-846 9040A/EPA 150.1 & 0.1 \\
\hline TDS & Total Dissolved solids & 40 CFR 136160.1 & 10,000 \\
\hline TOX & Total Organic Halogen & SW-846 9020 & 50 \\
\hline TOC & Total Organic Carbon & SW-846 9060 & 1,000 \\
\hline- & Anions by ion chromatograph per anion & EPA 300.0 & 500 \\
\hline
\end{tabular}




\begin{tabular}{|c|c|c|c|}
\hline - & Nitrate/Nitrate as $\mathbf{N}$ & EPA $353.1 / 2 / 3$ & 50 \\
\hline $12595-89-0$ & Chloride & EPA 300.0 & 1,000 \\
\hline $14265-44-2$ & Phosphorus as $\mathrm{PO}_{4}$ & EPA 300.0 & 500 \\
\hline $14797-55-8$ & Nitrate as $\mathrm{N}$ & EPA 300.0 & 100 \\
\hline $14808-79-8$ & Sulfate & EPA 300.0 & 10,000 \\
\hline $15984-48-8$ & Fluoride & EPA 300.0 & 500 \\
\hline $24959-67-9$ & Bromide & EPA 300.0 & 500 \\
\hline TEMPERATURE & Temperature in degrees Celsius & EPA 170.1 & 0.1 \\
\hline $13496-25-8$ & Sulfide & $S W-8469030$ & 1,000 \\
\hline- & Oil and Grease-Gasoline range & SW-846 9070 & 10,000 \\
\hline TSS & Total Suspended Solids & 40 CFR 160.2 & 4,000 \\
\hline \multicolumn{4}{|c|}{ Part 6. Radionuclides } \\
\hline Constituent ID & Constituent Name & Group & $\mathrm{CDL} \mathrm{pCi} / \mathrm{L}^{4}$ \\
\hline $10028-17-8$ & Tritium & LAB SPECIFIC & 400 \\
\hline $10098-97-2$ & Strontium-90 & LAB SPECIFIC & 2 \\
\hline 15046-84-1 & Iodine-129 & LAB SPECIFIC & 5 \\
\hline $7440-14-4$ & Radium- $228+226$ (total) & LAB SPECIFIC & 5 \\
\hline 13982-63-3 & Radium-226 & LAB SPECIFIC & 1 \\
\hline $7440-61-1$ & Uranium (gross) ug/L & LAB SPECIFIC & 0.1 \\
\hline AIPHA & Gross alpha & LAB SPECIFIC & 3 \\
\hline BETA & Gross beta & LAB SPECIFIC & 4 \\
\hline $15117-48-3$ & Plutonium-239/240 & LAB SPECIFIC & 1 \\
\hline $10045-97-3$ & Gamma Energy Analysis Cesium-137 & LAB SPECIFIC & 15 \\
\hline 14683-23-9 & Gamma Energy Analysis Europium-152 & LAB SPECIFIC & 50 \\
\hline $15585-10-1$ & Gamma Energy Analysis Europium-154 & LAB SPECIFIC & 50 \\
\hline $14391-16-3$ & Gamma Energy Analysis Europium-155 & LAB SPECIFIC & 50 \\
\hline $13967-48-1$ & Gamma Energy Analysis Ruthenium-106 & LAB SPECIFIC & 75 \\
\hline
\end{tabular}

Tentatively Identified Compound (MC)s will be reported.

2 PQL-Practical Quantitation Limit per 40 CFR 264. Appendix DX. Note: where no PQL was available, value was established at 10 times method detection limit. Values are expressed as micrograms per liter $(\mu g / L)$ unless otherwise noted.

3 Constituent must be specifically requested on analysis request forms.

- CDL-Contract Detection Linit which is expressed in pico curies per liter (pCi/). 
Appendix C

Charge Balance Calculations for Wells in the Vicinity of the TEDF 


\section{Appendix C}

\section{Charge Balance Calculations for Wells in the Vicinity of the TEDF}

The following tables are based on spreadsheet calculations of charge balance, ionic strength, and Total Dissolved Solids (TDS) for major ion concentrations in groundwater in 12 wells in the vicinity of the TEDF (see Figure 4.2). For each well, charge balance is calculated both with and without inclusion of $\mathrm{NO}_{3}{ }^{-}$. TDS values shown here for wells 699-40-36, 699-41-35, and 699-42-37 differ from those listed in Tables 4.1 through 4.3 for these wells This is because laboratory measurements of TDS include $\mathrm{H}_{4} \mathrm{SiO}_{4}{ }^{0}$, which adds significantly to the sum of dissolved solids, but does not affect charge balance. 
699-40-33A

$\begin{array}{lrrrr}\text { Constituent } & \mathrm{mg} / \mathrm{L} & \mathrm{mmolal} & \mathrm{meq} / \mathrm{L} & \% \text { total } \\ \mathrm{Na} & 51.5 & 2.24 & 2.24 & 66.69 \\ \mathrm{~K} & 6.28 & 0.16 & 0.16 & 4.78 \\ \mathrm{Ca} & 13.3 & 0.33 & 0.66 & 19.76 \\ \mathrm{Mg} & 3.58 & 0.15 & 0.29 & 8.77 \\ \text { total cations } & & & 3.36 & 100.00 \\ \mathrm{Cl} & 3.37 & 0.10 & 0.10 & 2.56 \\ \mathrm{SO4} & 0.97 & 0.01 & 0.02 & 0.54 \\ \text { alkalinity } & 180 & 1.80 & 3.60 & 96.90 \\ \mathrm{NO3} & 0 & 0.00 & 0.00 & 0.00 \\ \text { total anions } & & & 3.72 & 100.00\end{array}$

$\mathrm{pH}$ average $\quad 8.1$

$E$, charge balance(\%) total meq/L

ionic strength

TDS

$-5.04$

7.07

3.13E-03

187

with $\mathrm{NO} 3$

699-40-33A

Constituent

$\mathrm{Na}$

$\mathrm{K}$

$\mathrm{Ca}$

$\mathrm{Mg}$

total cations

$\mathrm{Cl}$

$\mathrm{SO} 4$

alkalinity

$\mathrm{NO} 3$

total anions

$\mathrm{E}$, charge balance $(\%)$

total meq/L

ionic strength

TDS

$\mathrm{mg} / \mathrm{L}$

51.5

6.28

13.3

3.58

3.37

0.97

180

0.13

mmolal

2.24

0.16

0.33

0.15

0.10

0.01

1.80

0.00

.10
.01
.80
.00

7.08

3.13E-03

$\begin{array}{rr}\text { meq/L } & \text { \% total } \\ 2.24 & 66.69 \\ 0.16 & 4.78 \\ 0.66 & 19.76 \\ 0.29 & 8.77 \\ 3.36 & 100.00 \\ 0.10 & 2.56 \\ 0.02 & 0.54 \\ 3.60 & 96.84 \\ 0.00 & 0.06 \\ 3.72 & 100.00\end{array}$

$-5.06$

Note: Nitrate and Alkalinity results may be suspect for this well

C. 2 
$699-40-36$

\begin{tabular}{|c|c|c|c|c|}
\hline \multicolumn{5}{|l|}{ Constituent } \\
\hline $\mathrm{Na}$ & 46.76 & 2.03 & 2.03 & 59.32 \\
\hline $\mathrm{K}$ & 7.7 & 0.20 & 0.20 & 5.74 \\
\hline $\mathrm{Ca}$ & 15.18 & 0.38 & 0.76 & 22.09 \\
\hline $\mathrm{Mg}$ & 5.35 & 0.22 & 0.44 & 12.84 \\
\hline total cations & & & 3.43 & 100.00 \\
\hline $\mathrm{Cl}$ & 3.33 & 0.09 & 0.09 & 3.02 \\
\hline SO4 & 5.67 & 0.06 & 0.12 & 3.79 \\
\hline alkalinity & 145 & 1.45 & 2.90 & 93.19 \\
\hline NO3 & 0 & 0.00 & 0.00 & 0.00 \\
\hline total anions & & & 3.11 & 100.00 \\
\hline $\mathrm{pH}$ average & 8 & & & \\
\hline \multicolumn{3}{|c|}{ E, charge balance $(\%)$} & 4.84 & \\
\hline total meq/L & & 6.54 & & \\
\hline ionic strength & & 3.20E-03 & & \\
\hline TDS & 170.99 & & & \\
\hline \multicolumn{5}{|l|}{ with $\mathrm{NO} 3$} \\
\hline \multicolumn{5}{|c|}{$699-40-36$} \\
\hline Constituent & $\mathrm{mg} / \mathrm{L}$ & mmolal & $\mathrm{meq} / \mathrm{L}$ & $\%$ total \\
\hline $\mathrm{Na}$ & 46.76 & 2.03 & 2.03 & 59.32 \\
\hline $\mathrm{K}$ & 7.7 & 0.20 & 0.20 & 5.74 \\
\hline $\mathrm{Ca}$ & 15.18 & 0.38 & 0.76 & 22.09 \\
\hline $\mathrm{Mg}$ & 5.35 & 0.22 & 0.44 & 12.84 \\
\hline total cations & & & 3.43 & 100.00 \\
\hline $\mathrm{Cl}$ & 3.33 & 0.09 & 0.09 & 3.02 \\
\hline SO4 & 5.67 & 0.06 & 0.12 & 3.7 \\
\hline alkalinity & 145 & 1.45 & 2.90 & 93.1 \\
\hline NO3 & 0.1 & 0.00 & 0.00 & 0.0 \\
\hline total anions & & & 3.11 & 100.0 \\
\hline \multirow{3}{*}{\multicolumn{2}{|c|}{$\begin{array}{l}\text { E, charge balance }(\%) \\
\text { total meq/L } \\
\text { ionic strength } \\
\text { TDS } \\
\end{array}$}} & & 4.81 & \\
\hline & & 6.54 & & \\
\hline & & $3.20 \mathrm{E}-03$ & & \\
\hline
\end{tabular}


699-40-39

$\begin{array}{lrrrr}\text { Constituent } & \mathrm{mg} / \mathrm{L} & \mathrm{mmolal} & \mathrm{meq} / \mathrm{L} & \% \text { total } \\ \mathrm{Na} & 32.85 & 1.43 & 1.43 & 44.76 \\ \mathrm{~K} & 4.84 & 0.12 & 0.12 & 3.88 \\ \mathrm{Ca} & 20.18 & 0.50 & 1.01 & 31.54 \\ \mathrm{Mg} & 7.69 & 0.32 & 0.63 & 19.82 \\ \text { total cations } & & & 3.19 & 100.00 \\ \mathrm{Cl} & 3.19 & 0.09 & 0.09 & 2.78 \\ \mathrm{SO} 4 & 3.93 & 0.04 & 0.08 & 2.53 \\ \text { alkalinity } & 153 & 1.53 & 3.06 & 94.68 \\ \mathrm{NO3} & 0 & 0.00 & 0.00 & 0.00 \\ \text { total anions } & & & 3.23 & 100.00 \\ & & & & \\ \text { pH average } & 8.03 & & & \\ & & & -0.61 & \\ \text { E, charge balance(\%) } & & & & \\ \text { total meq/L } & & 6.42 & & \\ \text { ionic strength } & & 3.31 \mathrm{E}-03 & & \\ \text { TDS } & 164.48 & & & \end{array}$

with $\mathrm{NO} 3$

699-40-39

Constituent

$\mathrm{mg} / \mathrm{L}$

$\mathrm{Na}$

4.84

$\mathrm{K}$

20.18

$\mathrm{Mg}$

7.69

mmolal

1.43

0.12

0.50

0.32

total cations

3.19

3.93

SO4

alkalinity

NO3

153

0.51

0.09

0.04

1.53

0.01

meq/L

1.43

0.12

1.01

0.63

3.19

0.09

0.08

3.06

0.01

3.24

$\%$ total

44.76

3.88

31.54

19.82

100.00

2.78

2.53

94.44

total anions

$E$, charge balance(\%) total meq/L

6.43

$-0.74$

ionic strength

3.31E-03

TDS

164.99 
$699-41-35$

$\begin{array}{lrrrr}\text { Constituent } & \mathrm{mg} / \mathrm{L} & \mathrm{mmolal} & \mathrm{meq} / \mathrm{L} & \% \text { total } \\ \mathrm{Na} & 42.24 & 1.84 & 1.84 & 51.91 \\ \mathrm{~K} & 6.42 & 0.16 & 0.16 & 4.64 \\ \mathrm{Ca} & 19.24 & 0.48 & 0.96 & 27.13 \\ \mathrm{Mg} & 7.02 & 0.29 & 0.58 & 16.32 \\ \text { total cations } & & & 3.54 & 100.00 \\ \mathrm{Cl} & 3.38 & 0.10 & 0.10 & 3.00 \\ \mathrm{SO4} & 6.64 & 0.07 & 0.14 & 4.36 \\ \text { alkalinity } & 147 & 1.47 & 2.94 & 92.64 \\ \mathrm{NO3} & 0 & 0.00 & 0.00 & 0.00 \\ \text { total anions } & & & 3.17 & 100.00 \\ & & & & \\ \text { pH average } & 7.9 & & & \\ & & & & \\ \text { E, charge balance(\%) } & & & & \\ \text { total meq/L } & & 6.71 & & \\ \text { ionic strength } & & 3.46 \mathrm{E}-03 & & \\ \text { TDS } & 173.14 & & & \end{array}$

with $\mathrm{NO} 3$

$699-41-35$

Constituent

$\mathrm{Na}$

$\mathrm{mg} / \mathrm{L}$

$\mathrm{K}$

42.24

6.42

$\mathrm{Ca}$

19.24

$\mathrm{Mg}$

7.02

total cations

$\mathrm{Cl}$

SO4

alkalinity

NO3

total anions

3.38

6.64

147

0.21

mmolal

1.84

0.16

0.48

0.29

0.10

0.07

1.47

0.00

meq/L

1.84

0.16

0.96

0.58

3.54

0.10

0.14

2.94

0.00

3.18

$\%$ total

51.91

4.64

27.13

16.32

100.00

3.00

4.35

92.54

0.11

100.00

E, charge balance(\%) total meq/L

ionic strength

TDS

173.35

6.72

3.46E-03

5.39 
$699-42-37$

$\begin{array}{lrrrr}\text { Constituent } & \mathrm{mg} / \mathrm{L} & \mathrm{mmolal} & \mathrm{meq} / \mathrm{L} & \% \text { total } \\ \mathrm{Na} & 35.75 & 1.56 & 1.56 & 41.93 \\ \mathrm{~K} & 4.88 & 0.12 & 0.12 & 3.37 \\ \mathrm{Ca} & 23.88 & 0.60 & 1.19 & 32.13 \\ \mathrm{Mg} & 10.17 & 0.42 & 0.84 & 22.57 \\ \text { total cations } & & & 3.71 & 100.00 \\ \mathrm{Cl} & 7.93 & 0.22 & 0.22 & 6.46 \\ \mathrm{SO} 4 & 23.97 & 0.25 & 0.50 & 14.41 \\ \text { alkalinity } & 137 & 1.37 & 2.74 & 79.13 \\ \mathrm{NO3} & 0 & 0.00 & 0.00 & 0.00 \\ \text { total anions } & & & 3.46 & 100.00\end{array}$

$\mathrm{pH}$ average

8.1

E, charge balance(\%) total meq/L

ionic strength

7.17

TDS

188.78

4.16E-03

with $\mathrm{NO} 3$

$699-42-37$

Constituent

$\mathrm{Na}$

$\mathrm{mg} / \mathrm{L}$

mmolal

1.56

0.12

4.88

0.60

0.42

$\mathrm{Mg}$

23.88

10.17

total cations

7.93

23.97

137

2.76

0.22

0.25

1.37

0.04

meq/L

1.56

$\%$ total

0.12

41.93

1.19

3.37

0.84

32.13

22.57

3.71

100.00

0.22

6.38

alkalinity

NO3

total anions

0.50

14.23

2.74

78.12

0.04

1.27

3.51

100.00

$E$, charge balance $(\%)$ total $\mathrm{meq} / \mathrm{L}$

ionic strength

TDS 
$699-42-39 B$

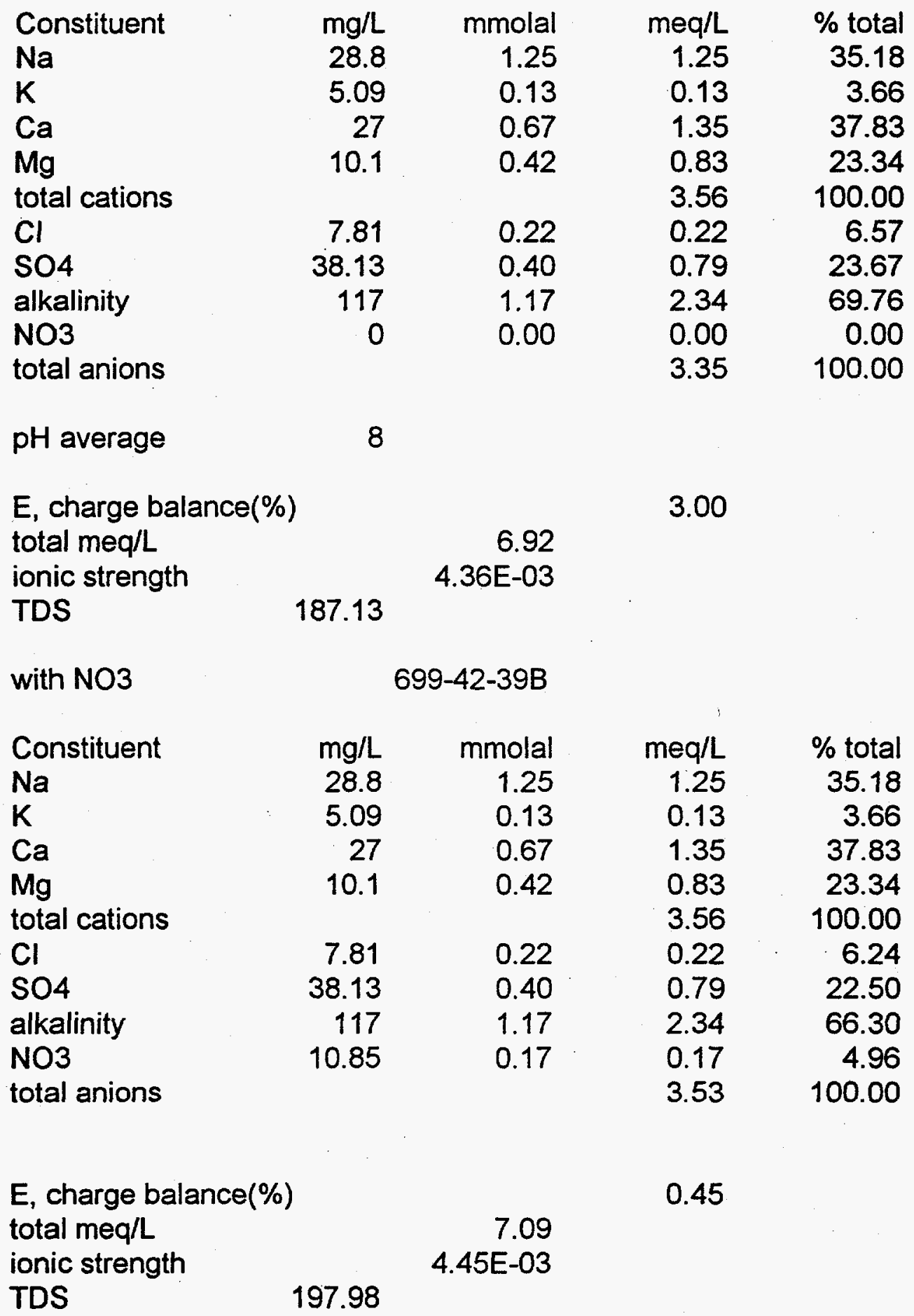


$699-42-40 A$

$\begin{array}{lrrrr}\text { Constituent } & \mathrm{mg} / \mathrm{L} & \mathrm{mmolal} & \mathrm{meq} / \mathrm{L} & \% \text { total } \\ \mathrm{Na} & 4.4 & 0.19 & 0.19 & 10.93 \\ \mathrm{~K} & 2.82 & 0.07 & 0.07 & 4.12 \\ \mathrm{Ca} & 20.85 & 0.52 & 1.04 & 59.43 \\ \mathrm{Mg} & 5.43 & 0.22 & 0.45 & 25.52 \\ \text { total cations } & & & 1.75 & 100.00 \\ \mathrm{Cl} & 3.07 & 0.09 & 0.09 & 4.62 \\ \text { SO4 } & 12.84 & 0.13 & 0.27 & 14.27 \\ \text { alkalinity } & 76 & 0.76 & 1.52 & 81.11 \\ \mathrm{NO3} & 0 & 0.00 & 0.00 & 0.00 \\ \text { total anions } & & & 1.87 & 100.00 \\ & & & & \\ \text { pH average } & 8 & & & \\ & & & & \\ \text { E, charge balance(\%) } & & & -3.40 & \\ \text { total meq/L } & & 3.62 . & & \\ \text { ionic strength } & & 2.31 \mathrm{E}-03 & & \\ \text { TDS } & 95.01 & & & \end{array}$

with $\mathrm{NO} 3$

$699-42-40 A$

Constituent

$\mathrm{mg} / \mathrm{L} \quad \mathrm{mmolal}$

$\begin{array}{ll}4.4 & 0.19 \\ 2.82 & 0.07\end{array}$

meq/L

0.19

$\%$ total

0.07

10.93

$\mathrm{K}$

20.85

0.52

4.12

$\mathrm{Ca}$

5.43

0.22

1.04

59.43

$\mathrm{Mg}$

3.07

0.09

0.45

25.52

total cations

1.75

100.00

$\mathrm{SO} 4$

12.84

0.13

0.09

4.46

alkalinity

76

0.76

0.27

13.77

4.22

0.07

1.52

0.07

78.27

total anions

1.94

3.50

100.00

$E$, charge balance(\%) total meq/L ionic strength TDS 
$699-43-40$

Constituent

$\mathrm{Na}$

$\mathrm{K}$

$\mathrm{Ca}$

$\mathrm{Mg}$

total cations

$\mathrm{Cl}$

SO4

alkalinity

NO3

total anions

$\mathrm{pH}$ average

$E$, charge balance $(\%)$ total meq/L

ionic strength

TDS

with NO3

Constituent
$\mathrm{Na}$
$\mathrm{K}$
$\mathrm{Ca}$
$\mathrm{Mg}$
total cations
$\mathrm{Cl}$
$\mathrm{SO} 4$
alkalinity

$\mathrm{NO} 3$

total anions

E, charge balance $(\%)$ total meq/L ionic strength TDS $\mathrm{mg} / \mathrm{L}$ 20.08 5.04 25.36

9.97

6.47

31.15

109

6.24

mmolal
0.87
0.13
0.63
0.41

0.18
0.32
1.09
0.00

0.00
8

1.26

6.10

3.87E-03

$699-43-40$

mmolal

0.87

0.13

0.63

0.41

0.18

0.32

1.09

0.10

0.10

1.26

$\begin{array}{rr}\text { meq/L } & \text { \% total } \\ 0.87 & 28.28 \\ 0.13 & 4.17 \\ 1.27 & 40.98 \\ 0.82 & 26.57 \\ 3.09 & 100.00 \\ 0.18 & 6.06 \\ 0.65 & 21.54 \\ 2.18 & 72.40 \\ 0.00 & 0.00 \\ 3.01 & 100.00\end{array}$


699-43-41E

Constituent

$\mathrm{Na}$

$\mathrm{K}$

$\mathrm{Ca}$

$\mathrm{Mg}$

total cations

$\mathrm{Cl}$

$\mathrm{SO} 4$

alkalinity

NO3

total anions

$\mathrm{pH}$ average

$E$, charge balance $(\%)$

total meq/L

ionic strength

TDS

with $\mathrm{NO} 3$

Constituent

$\mathrm{Na}$

$\mathrm{K}$

$\mathrm{Ca}$

$\mathrm{Mg}$

total cations

$\mathrm{Cl}$

SO4

alkalinity

NO3

total anions $\mathrm{mg} / \mathrm{L}$ mmolal

25.1

4.14

25.1

9.3

6.61

30.43

111

0

8.4

1.09

0.11

0.63

0.38

0.19

0.32

1.11

0.00

meq/L

1.09

0.11

1.25

0.77

3.22

0.19

0.63

2.22

0.00

3.04

$\%$ total

33.95

3.29

38.95

23.80

100.00

6.13

20.84

73.03

0.00

100.00

2.80

6.26

3.90E-03

167.28

\section{9-43-41E}

$\mathrm{mg} / \mathrm{L}$

mmolal

1.09

0.11

0.63

0.38

25.1

9.3

6.61

0.19

0.32

1.11

111

0.15

meq/L

1.09

$\%$ total

0.11

33.95

1.25

3.29

0.77

38.95

3.22

23.80

100.00

0.19

5.85

0.63

19.89

2.22

69.68

0.15

4.59

3.19

100.00

E, charge balance(\%)

total $\mathrm{meq} / \mathrm{L}$

6.40

0.46

ionic strength

TDS

176.34

3.97E-03

C.10 
699-43-41F

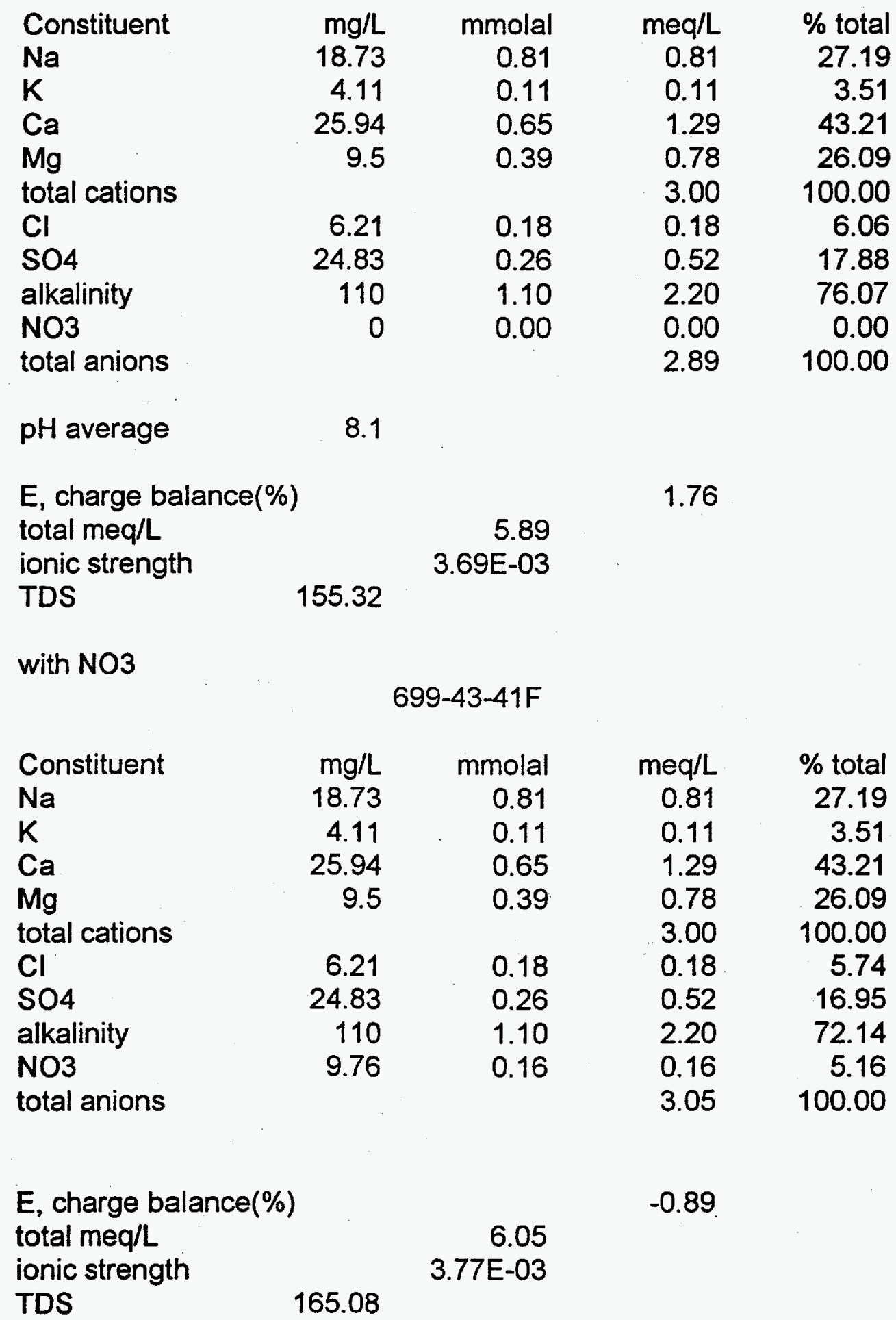


$699-43-41 G$

$\begin{array}{lrrrr}\text { Constituent } & \mathrm{mg} / \mathrm{L} & \mathrm{mmolal} & \mathrm{meq} / \mathrm{L} & \% \text { total } \\ \mathrm{Na} & 20.75 & 0.90 & 0.90 & 30.28 \\ \mathrm{~K} & 4.98 & 0.13 & 0.13 & 4.27 \\ \mathrm{Ca} & 23.33 & 0.58 & 1.16 & 39.06 \\ \mathrm{Mg} & 9.56 & 0.39 & 0.79 & 26.39 \\ \text { total cations } & & & 2.98 & 100.00 \\ \mathrm{Cl} & 5.45 & 0.15 & 0.15 & 5.43 \\ \text { SO4 } & 26.76 & 0.28 & 0.56 & 19.68 \\ \text { alkalinity } & 106 & 1.06 & 2.12 & 74.89 \\ \text { NO3 } & 0 & 0.00 & 0.00 & 0.00 \\ \text { total anions } & & & 2.83 & 100.00\end{array}$

$\mathrm{pH}$ average

8.4

E, charge balance $(\%)$ total $\mathrm{meq} / \mathrm{L}$

ionic strength

TDS

154.43

2.58

3.63E-03

with $\mathrm{NO} 3$

$699-43-41 G$

Constituent

$\mathrm{Na}$

$\mathrm{mg} / \mathrm{L} \quad \mathrm{mmolal}$

20.75

0.90

meq/L

$\%$ total

4.98

0.13

0.90

30.28

$\mathrm{K}$

23.33

0.58

0.13

4.27

$\mathrm{Ca}$

9.56

1.16

39.06

$\mathrm{Mg}$

0.39

0.79

26.39

total cations

5.45

0.15

2.98

100.00

$\mathrm{Cl}$

26.76

0.28

0.15

5.26

SO4

106

1.06

0.56

19.07

5.59

0.09

2.12

72.58

NO3

0.09

3.09

total anions

2.92

100.00

E, charge balance(\%)

total meq/L

ionic strength

TDS

5.90

1.01

3.67E-03

160.02 
$699-44-39 B$

Constituent

$\mathrm{Na}$

$\mathrm{K}$

$\mathrm{Ca}$

$\mathrm{Mg}$

total cations

$\mathrm{Cl}$

$\mathrm{SO} 4$

alkalinity

NO3

total anions

$\mathrm{pH}$ average

$E$, charge balance(\%) total meq/L

ionic strength

TDS

with NO3

Constituent

$\mathrm{Na}$

$\mathrm{K}$

$\mathrm{Ca}$

$\mathrm{Mg}$

total cations

$\mathrm{Cl}$

$\mathrm{SO} 4$

alkalinity

NO3

total anions $\mathrm{mg} / \mathrm{L}$

6.16

3.23

20.13

7.56

2.73

13.54

82

0

8

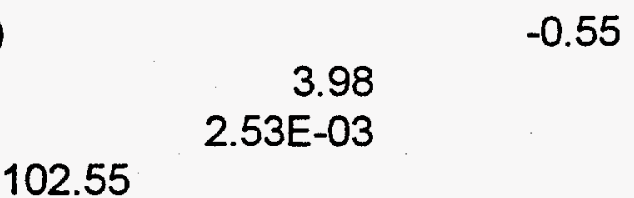

$699-44-39 B$

$\mathrm{mg} / \mathrm{L}$

6.16

3.23

20.13

7.56

2.73

13.54

82

1.63

0.08

0.14

0.82

0.00

0.27

0.08

0.50

0.31

0.00

8

$699-44-39 B$

mmolal

0.27

0.08

0.50

0.31

0.08

0.14

0.82

0.03

meq/L

0.27

0.08

1.00

0.62

1.98

0.08

0.28

1.64

0.03

2.03

$-1.20$

$E$, charge balance(\%) total meq/L ionic strength

TDS
4.00

2.55E-03

104.18
$\%$ total

13.55

4.18

50.81

31.46

100.00

3.85

14.10

82.04

0.00

100.00 


\section{Distribution}

No. of

Copies

\section{ONSITE}

9 Waste Management Federal Services, Inc.

D. L. Flyckt

R. D. Haggard

P. C. Mohondro (2)

P. M. Olson (5)
No. of

Copies

26 Pacific Northwest National Laboratory

D. B. Barnett (15)

K6-81

M. P. Bergeron

K9-36

R. G. Riley

K6-96

E. C. Thornton

K6-96

W. D. Webber

K6-96

Information Release Office (7)

K1-06 